Historic, Archive Document

Do not assume content reflects current scientific knowledge, policies, or practices. 

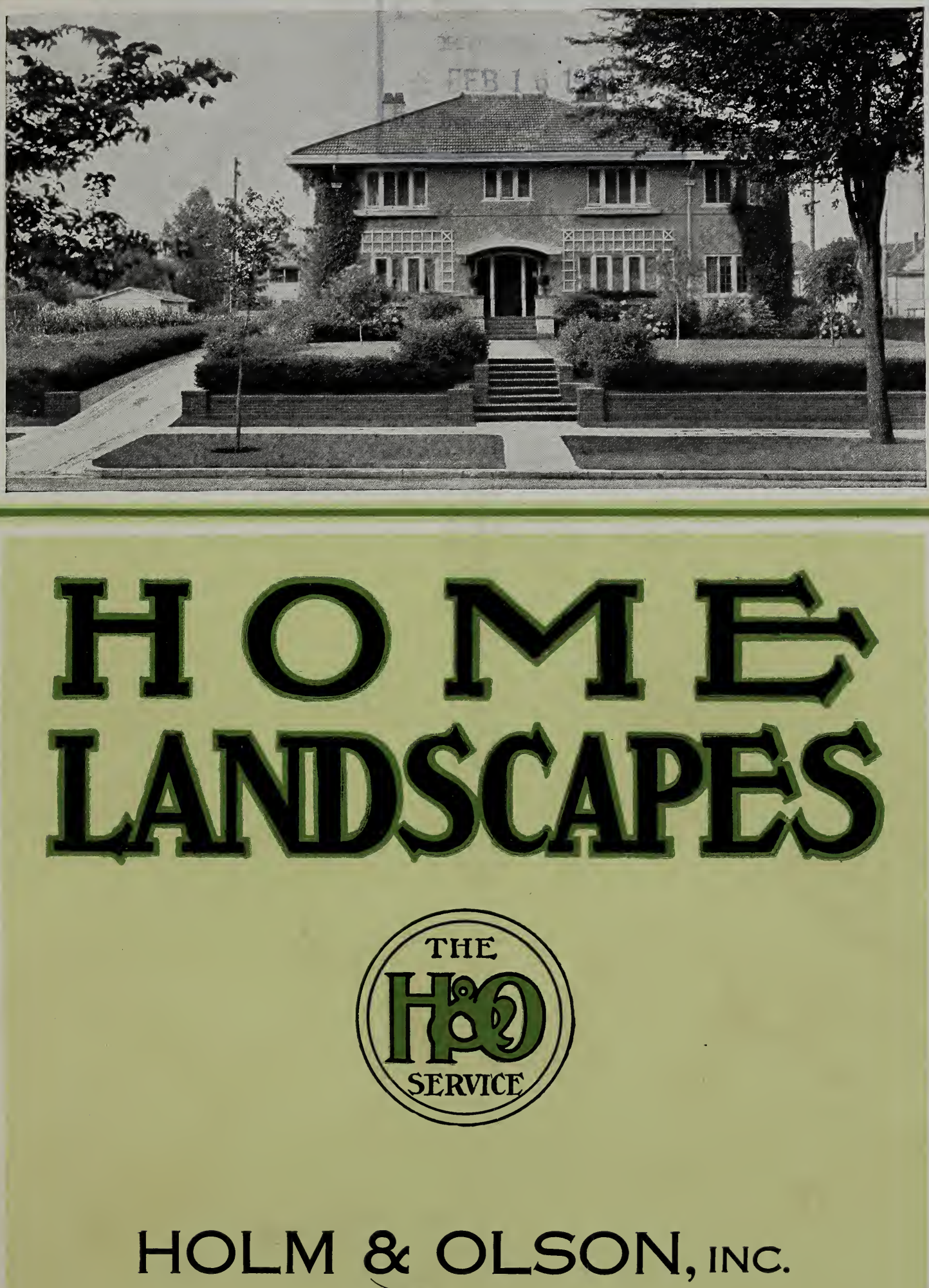

THE PARK NURSERIES 


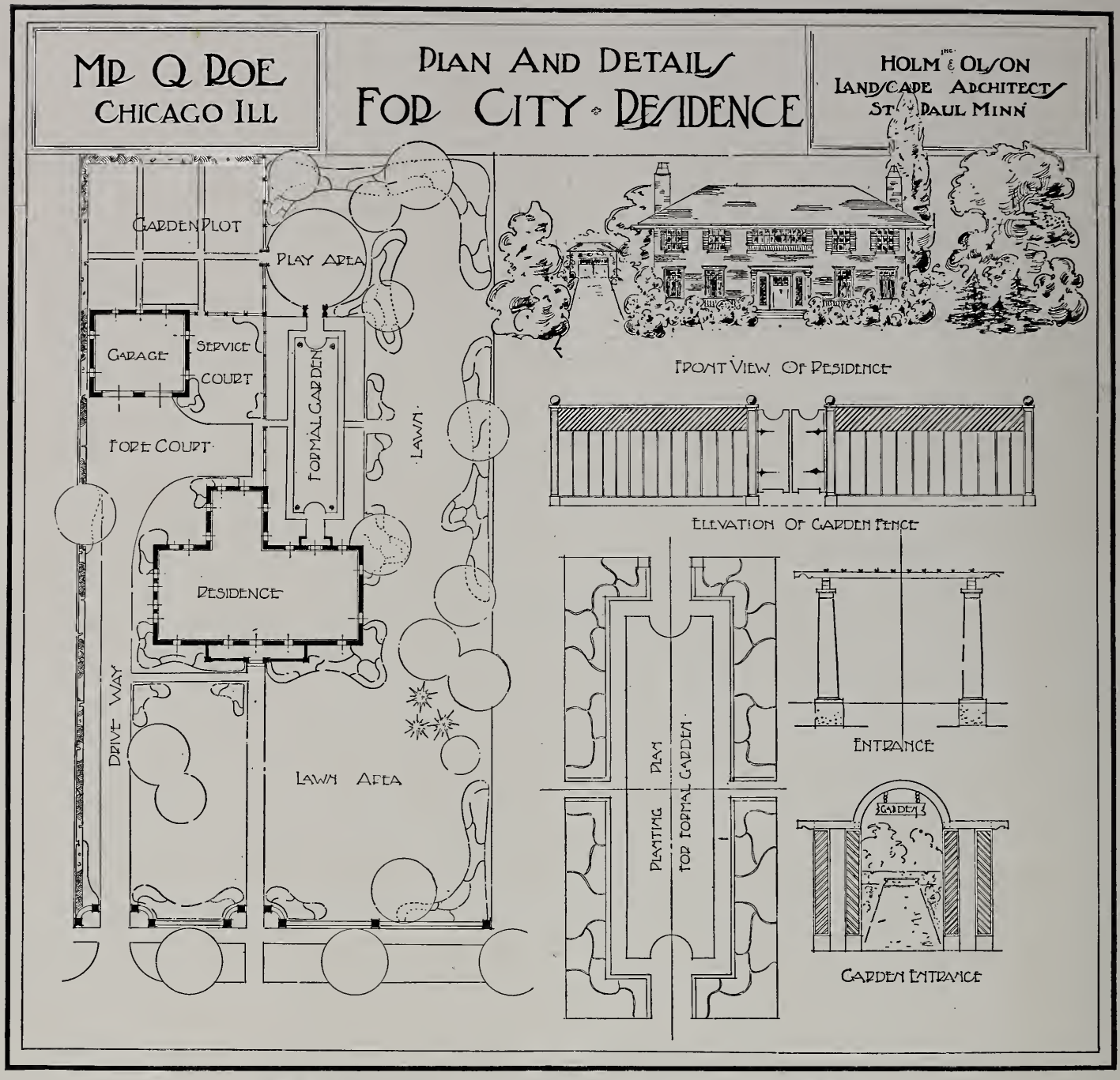

\section{PLANNING YOUR LANDSCAPE}

An attractively planted ground in any community is a force that cannot be overlooked; it has a tendency to make people desire to live in such a neighborhood, and to increase property values. The house can be made to do its part in the completed picture only when set in proper surroundings. Too often the owner forgets this when arranging the landscape, and the result is unattractive. The planting about the bungalow and the colonial house must be designed to harmonize with the architecture.

\section{A LANDSGAPE PLAN}

Every landscape proposition should have a plan. The beauty of a planting depends on having the trees properly located having in mind making the grounds look larger than they really are, with a broad, open lawn, keeping the planting around the outside borders. Another important object is the use of proper material about the foundation "to pin the house to the ground," and work out a solution for the service portion of the premises so you may have the necessary privacy.

\section{THE COST OF PLANNING}

The cost of plans for home grounds; is based on percentage basis, 15 per cent when the material cost $\$ 100.00$ or less, 10 per cent when the material amounts to over $\$ 100.00$. For example when the material for planting the grounds amounts to $\$ 150.00$, the plans will cost $\$ 15.00$, payable by the 10 th of the month following. When the material for the planting is purchased, credit will then be given for the amount of the plans or the portion which has been ordered.

We have landscape architects who are constantly on the road, making calls, and looking after work under construction and if you will write us, we will try and arrange a call when in your section. This should be done as long in advance as possible. This assists in keeping down expenses. Write about your wants and requirements and we will be pleased,to advise.

\section{COST OF H. \& O. SERVICE}

Special service of a Landscape Architect costs from $\$ 15.00$ to $\$ 25.00$ per day and his expenses, when it is necessary to make a visit. All plans where planting material is not needed will be charged for the time of service in working out the drawings; such as grading plans, walls, buildings, cemeteries, pergolas, pools, etc., etc., or where grounds are to be replanned, using material on grounds. Men for superintending plantings will be furnished as far as we are able to supply under existing conditions, and prices will be quoted for such service.

Charts will be sent, showing how to take measurements. With the measurements and photographs we can work out planting plans, unless the grading and the walks and drives would need special service.

\section{COST OF MATERIAL}

We grow our own planting material, in our own Nurseries, knowing just what is hardy. This in itself is worthy of your consideration, to know you will get just such varieties as will do best. Stock is sold F. O. B. St. Paul.

Our stock is grown especially for our Landscape plantings and is much better in quality than that usually sold; further, our specialty is Ornamental Nursery material.

We do not enter competition either in Landscape work or the sale of material, we offer you a "service" that is not maintained by any firm in the West. We plan and design your grounds, furnish the material grown in our own Nurseries, furnish you a competent Landscape Gardener to superintend the planting; in other words, we will do the entire work, guarantee you entire satisfaction, and the responsibility rests only with us. 


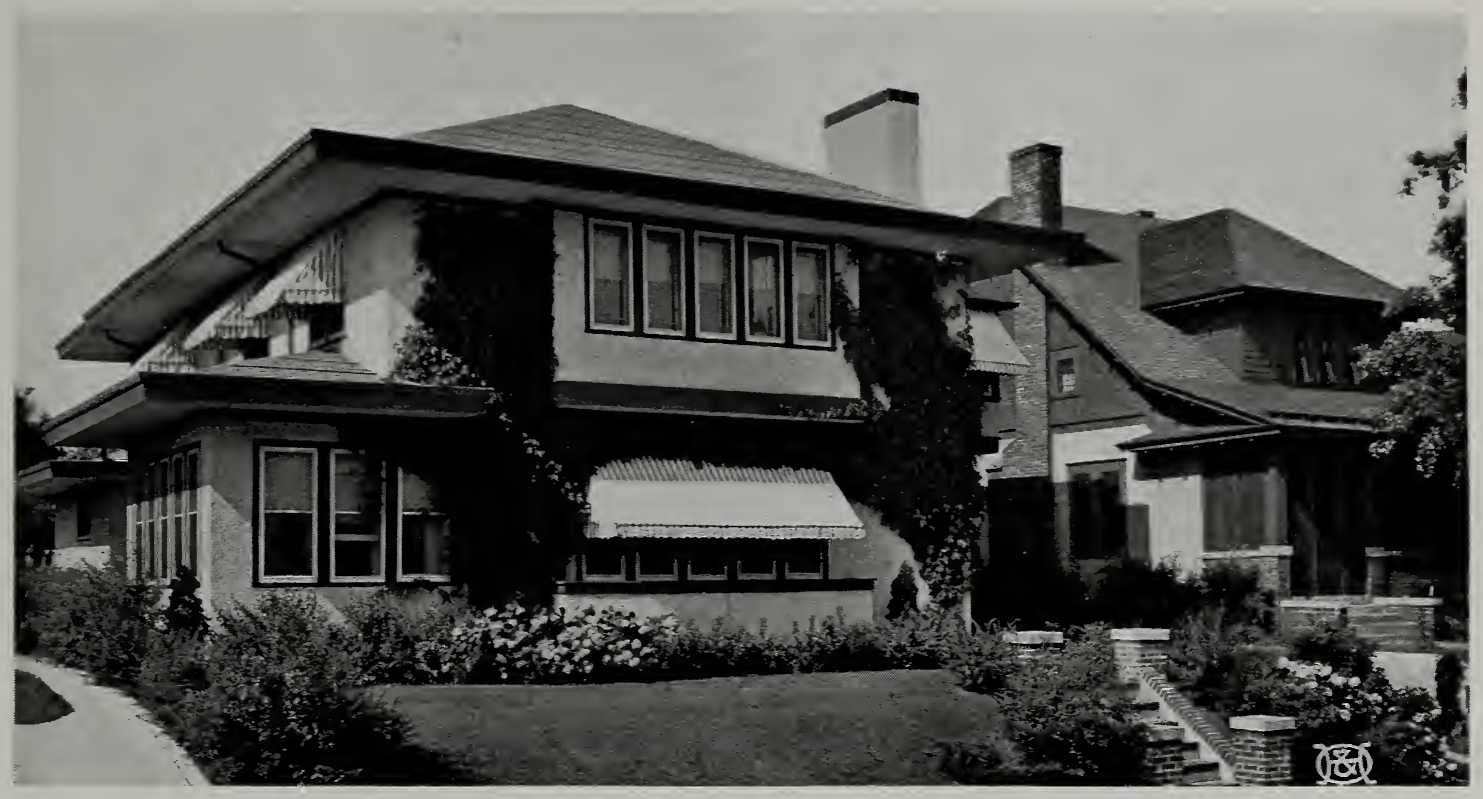

The home-like appearance given by a well-balanced planting

\section{OUR CATALOGUES}

THE education we have endeavored to give all lovers of beautiful home grounds in 1 the past, has brought to us so much joy, both from our clients and the press, that it inspires us to greater activities along these educational lines, and from year to year you may expect we will set the example that others may follow.

Home Landscapes-This one. A booklet most fitting for any one interested in beautifying their home grounds. It is condensed and to the point, with beautiful illustrations all representing work done by the "H. \& O. SERVICE."

Creating Your Landscape-Our booklet of two years ago, said to be the most artistic and best booklet ever issued on the subject. We are fortunate enough to still have a supply of these on hand, and will be pleased to mail copies to those who are in need. This book gives descriptions of all trees, shrubs, evergreens and plants, and is illustrated in color, giving many engravings of beautiful homes, etc. This booklet is mailed free but its prices have been withdrawn and prices for 1920 are given in Home Landscapes.

Landscape Development-2nd Edition. Price $60 \mathrm{c}$, postage paid. This beautiful booklet has created such a demand it has been necessary for us to issue a second edition, which will be ready for mailing about December 15th.

Landscape Development is different from all other booklets. Its texts treat on all subjects of landscape art and the texts are practical and to the point, written by one familiar with the practical end of the work. It treats on the following subjects:

The Making of Home Grounds Beautiful,

The Making of Japanese Gardens,

The Making of Formal Gardens,

The Making of an Old Fashioned Garden,

The Making of an Attractize Back Yard,

The Making of Public Parks,

The Making of Cemeteries Beautiful,

The Making of Town and Country Clubs,

The Making of School Grounds,

The Making of Hospital Grounds,

The Making of a College Campus,

The Making of Factory Grounds Attractive,

The Making of Public Grounds Beautiful,

The Making of Driveways and Walks,

The Cost of Beautifying Grounds,

The Making of Lawns,

The Setting for Lawns and Gardens,

The Designing of Real Estate Sub-divisions.

\section{NURSERY PRODUGTS AFTER THE WAR}

War conditions of the past four years have had their effect. Men were drawn from this industry to what was termed "essentials," hence every nursery in the country with its increased demand for material, finds its stock "short," caused by shortage of labor, and high cost of labor. The cost going into the production of nursery material is from 60 to 70 per cent labor, hence one can see that it will be some time before there can be much of a reduction in prices; moreover, this is not a manufactured product, but it takes years for it to grow. 
WHERE THE PARK NURSERIES ARE

A T the eastern gate of Uncle Sam's mighty inland empire of the great Northwest stand two large cities, St. Paul and Minneapolis. These huge bee-hives of busy workers are so close together that a half-hour's brisk ride by train or motor will easily take you from one to the other. About half-way between these two land-marks of prosperity, just at the residential outskirts of Minnesota's state capital, St. Paul, are The Park Nurseries, the establishment built by the pluck and skill of Holm \& Olson, Inc.

The Park Nurseries were founded primarily to furnish the residents of the Twin Cities the means to make their home grounds beautiful; and, secondly, to afford our citizens an opportunity of consulting with skilled landscape designers and plantsmen, who by reason of training and experience are able to give intelligent advice to all who are interested in ornamental plantings.

Many home-owners have taken advantage of the facilities offered, and today their grounds are pointed out as among the noted places in the Twin Cities. Aside from the personal pride involved, these homeowners are conscious of adding to the beauties of the community, and realize that well-planned grounds increase the intrinsic worth of their property.

\section{ADVANTAGES OF PLANTING}

$\mathrm{M}$ ANY home-owners think they have an attractive home if the house is well built and the ground covered with a carpet of grass. The value of trees, shrubs, roses, and perennials is not fully understood by them, else they would never be satisfied with only a lawn to add beauty to their grounds.

To be sure the rich green lawn does add character; it is indispensable, but it is only the first step in landscape work. It really forms the basis of the design, that on which the craftsman arranges the large shrubs and trees so that the individual pieces form one harmonious whole.

First, let us consider the matter from an esthetic standpoint. This can be well explained by a homely illustration: If you were at a formal society function and saw a man without a collar and tie, you could plainly see that he was out of place. Now then, the absence of the collar and tie to the man at an evening party is just as defined as the absence of trees and shrubs from the home grounds. When the grounds are correctly arranged with the proper trees or shrubs, your landscape picture is complete. Welllaid-out grounds are more pleasing, both to you and the passerby, than grounds that are devoid of those important adjuncts.

Let us consider the second reason for planting, that of increased value. Just ask yourself this question: "Would I be willing to pay more for an attractive place than for one that is bare and uninviting?" If you can answer "Yes" to this question, you have also answered "Yes" to the question "Should I plant my grounds?"

\section{THE IMPORTANCE OF A PLAN}

A

PLAN is just as important in laying out the grounds as in painting a masterpiece. Every bit of rolling ground must be considered; the location of the house, the walks and drives; whether or not absolute privacy is desired. All these must be kept in mind when preparing the landscape plan. Therefore, you will readily see the advantages of having a competent landscape-designer plan your grounds. Such a man must be familiar with all the details of home-ground arrangement as well as thoroughly conversant with the plants to be used.

Men who know these necessary points are at your command if you employ the Holm \& Olson Landscape Service. This Service begins with a personal inspection and a careful survey of the grounds to be planted. A sketch of the proposed planting, together with a list of the plants to be used, is then made and submitted to you for approval. When you approve, we then proceed with the actual planting.

In selecting the individual plants we prefer to have you come to the nursery and personally select the specimens you wish. If a personal visit cannot be arranged, we use our best judgment in the selection of stock.

The trees and plants that are chosen are now carefully dug and loaded on trucks, and transferred to the place where they are to be planted, or to the express or freight station. Our plantsmen do the actual work of setting the trees or plants, as only experts can do. Everything to insure the growth of the plants is carefully done, for until you are pleased with our work we are not satisfied.

\section{A VISIT TO THE NURSERIES IS DESIRABLE}

$T$ HERE is always much satisfaction in seeing a thing before you buy it, for then you get a more definite idea of what it is like. Especially so is this true when applied to trees, shrubs, and plants-the products of a nursery. The reason is obvious. Many people send long distances for trees or plants, and, when they are set in place on the grounds, it is found that they are not at all what was wanted. This can be overcome by personal inspection at a convenient and reliable nursery.

Come to the Park Nurseries and look at our stock as it stands in the nursery row. You will find a larger list of varieties from which to select than in any other nursery in the West. The tree or shrub is there in its natural growth, and it is easy to form a mental picture of the same tree growing on your own grounds. Ask our Superintendent, who conducts you, all the questions you wish. If you see anything you like, have him tag it for you. When the proper planting time comes, it will be properly dug and promptly removed to your place, or shipped to any point you designate.

\section{HOW TO REACH THE NUR- SERIES}

\section{GAR SERVICE DIRECT TO NURSERY ENTRANCE}

$T$

HE Park Nurseries are accessible from St. Paul, Minneapolis, and all adjacent points. From any down-town point take St. ClairHope car, and get off at Evergreen Place, the entrance to the Park Nurseries. From points in Minneapolis, take St. Paul-Minneapolis, Como-Harriet, or Selby-Lake car, transferring at Snelling Crosstown to the St. Clair-Hope line, which brings you direct to the nursery entrance at Evergreen Place. If motoring or driving, use Lexington Avenue, south of Summit, to St. Clair Street. 


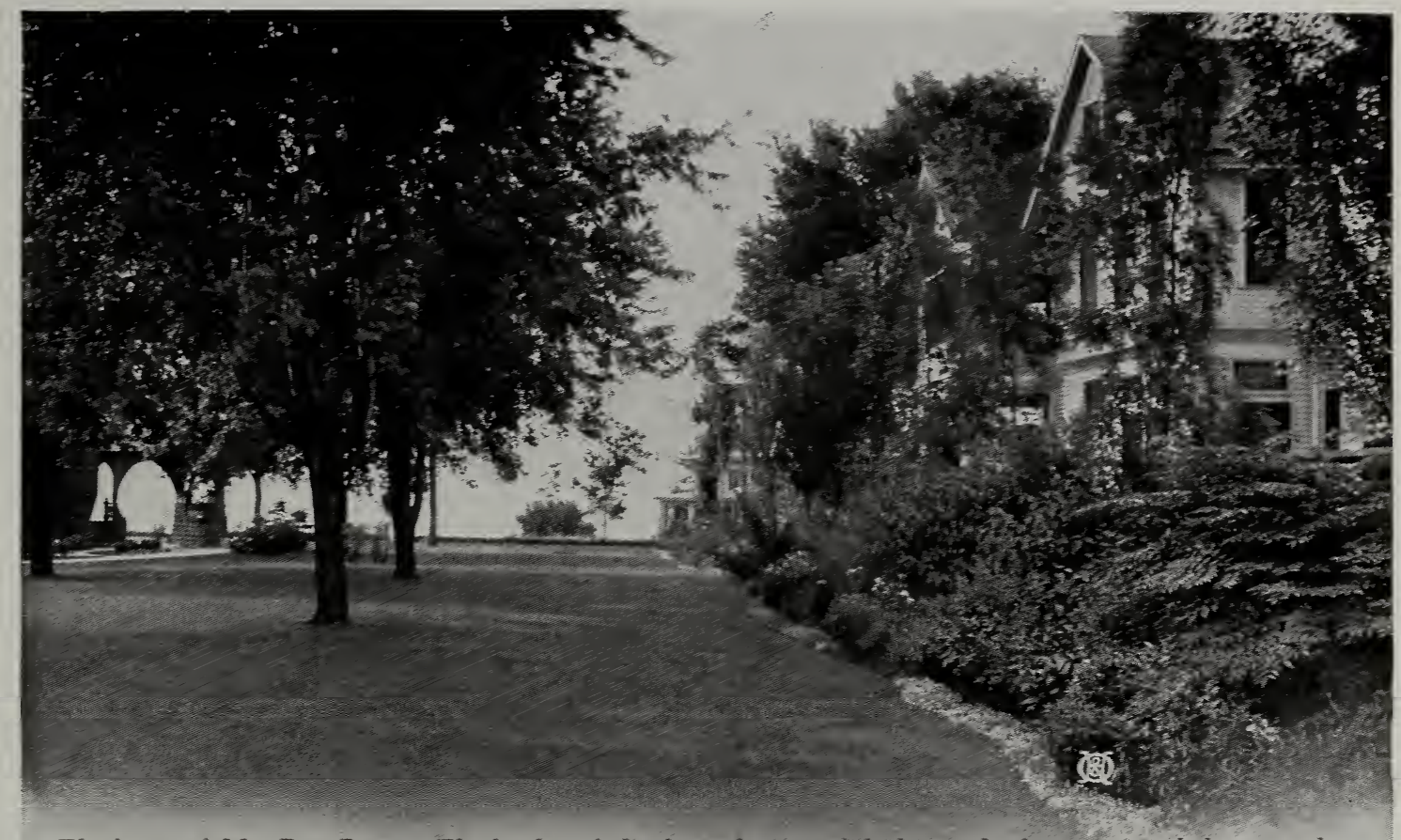

The home of Mr. Ben Baer. The border of shrubs and perennials formis the frame around the grounds

\section{ORNAMENTAL TREES}

W E strongly urge the importance of the proper preparation of the soil before planting. The usual method practised by many planters is to dig holes much too small for the tree that took years to grow; if this is done, its life is cut off or the growth is checked.

Transplanted Trees. The question is often asked, "IThat do you mean by Transplanted Trees?" Just this: Te are not what is termed a "Commercial Nursery"; we grow nursery stock from a landscape standpoint, making a specialty of ornamentals for beautifying city and country homes. We transplant our trees and shrubs into nursery rows, setting them twice and three times the usual distances apart, cutting them back to make them put on a bushy head and heavier stem, and, most important, a better root-system.

What Are Specimen Trees? Specimen trees are selections that have been transplanted from time to time, have grown into large sizes, and can be moved safely, giving quick results.

Alder, European (Almus glutinosa). Each 10
8 to $10 \mathrm{ft} ., 1 \frac{1}{2}$ in.dia.,transplanted $\$ 250 \$ 2200$

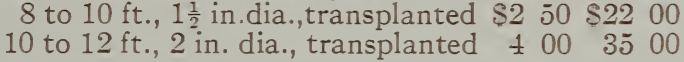

Ash, American White (Fraximus Americana).

6 to $8 \mathrm{ft}$.

8 to $10 \mathrm{ft}$., $1 \frac{1}{4}$ to $1 \frac{1}{2}$ in. diameter, transplanted.

10 to $12 \mathrm{ft}$., $1 \frac{1}{2}$ to 2 in. diameter, transplanted.

10 to $12 \mathrm{ft}$., 2 to $2 \frac{1}{2}$ in. diameter, transplanted.

12 to $1 \pm \mathrm{ft}$., $2 \frac{1}{2}$ to 3 in. diameter, transplanted.

12 to $1 \pm \mathrm{ft}$., 3 to 4 in. diameter, transplanted.

Specimen trees...... si to 2000

Box Elder (Acer Negundo). See Ash-leaved Maple, page 4 . $\begin{array}{llll}\text { Each } & 10 & 100 & 100\end{array}$

125120010000

200180015000

300250022500

5004500

5000500

7006500

Birch, Black (Betula lutea).

4 to $5 \mathrm{ft}$

5 to $6 \mathrm{ft}$.

6 to $8 \mathrm{ft}$., transplanted

8 to $10 \mathrm{ft}$., $1 \frac{1}{2}$ to $1 \frac{3}{4}$ in. diam., trans.

Specimen trees.

$\$ 5$ to

\begin{tabular}{rrrr}
\multicolumn{2}{c}{ Each } & \multicolumn{1}{c}{10} \\
$\$ 0$ & 75 & $\$ 6$ & 00 \\
1 & 00 & 9 & 00 \\
1 & 50 & 13 & 00 \\
2 & 50 & 22 & 00 \\
7 & 50 & &
\end{tabular}

Birch, European White (Betula alba). 5 to $6 \mathrm{ft}$., transplanted 6 to $8 \mathrm{ft}$., transplanted

8 to $10 \mathrm{ft}, 1 \frac{1}{2}$ to 13 in diam trans.

10 to $12 \mathrm{ft}$., 2 to $2 \frac{1}{2} \mathrm{in}$. diam., trans. Specimen trees.
Birch, Paper or Canoe (Betula papyrifera).

5 to $6 \mathrm{ft}$.

$\$ 125 \$ 11^{10} 00$

6 to $8 \mathrm{ft}$., transplanted........... $175 \quad 1500$

8 to $10 \mathrm{ft}$., $1 \frac{1}{4}$ to $1 \frac{1}{2}$ in. diam., trans. $3002-00$ Specimen trees.

Butternut (Juglans cinerea). Each $10 \quad 100$

6 to $8 \mathrm{ft}$

8 to $10 \mathrm{ft}$

Specimen trees.

$\$ 100 \$ 900 \$ 7500$

$\begin{array}{lllll}1 & 50 & 13 & 00\end{array}$

Catalpa speciosa (Western Catalpa

6 to $8 \mathrm{ft} \ldots \ldots \ldots \ldots \ldots$......... \$0 $75 \$ 800 \$ 5000$

8 to $10 \mathrm{ft} ., 1 \frac{1}{2}$ in. diam., trans. 1251100.9000

10 to $12 \mathrm{ft}$., $1 \frac{1}{2}$ to 2 in. diameter, transplanted.

10 to $12 \mathrm{ft}$., 2 to $2 \frac{1}{2}$ in. diam-

eter, transplanted........ $300 \quad 2700$

Specimen trees....... \$5 to 2500

Catalpa Bungei. Dwarf.

2 -yr. heads.

3 -yr. heads, transplanted.

Specimen trees

250230020000

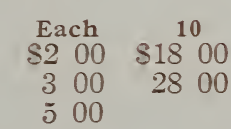

Cherry, American Bird (Cerasus serotina).

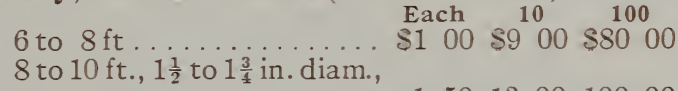

trans............... $150 \quad 1300 \quad 10000$

10 to $12 \mathrm{ft}$., 2 to $2 \frac{1}{2}$ in. diam., tr. 3002800

Cherry, European (Cerasus alium flore pleno alba).
\pm to $5 \mathrm{ft}$.

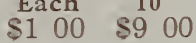
5 to $6 \mathrm{ft} . .$.
$\begin{array}{llll}1 & 50 & 13 & 00\end{array}$ 
Chestnut, American (Castanea Americana).

4 to $5 \mathrm{ft}$.

Each

5 to $6 \mathrm{ft}$.

$\$ 075$

100

$\$ 600$

900

Crab, Bechtel's Flowering (Pyrus angustifolia).

3 to $4 \mathrm{ft}$.

4 to $5 \mathrm{ft}$., transplanted.

$\$ 150 \quad \$ 1200$

Specimens.

$\$ 350$ to 200

1800

Crab, Floribunda (Pyrus floribunda).

3 to $4 \mathrm{ft}$., transplanted...

$\$ 100 \$ \$ 900$

4 to $5 \mathrm{ft}$., transplanted.

$150 \quad 1300$

Crab Parkman's (Pyrus Parkmani).

3 to $4 \mathrm{ft}$., transplanted..

$\$ 150 \quad \$ 1300$

4 to $5 \mathrm{ft}$., transplanted.

$200 \quad 1800$

Crab, Soulard's (Pyrus Soulardii).

3 to $4 \mathrm{ft}$.

4 to $5 \mathrm{ft}$

Elm, Huntingdon (Ulmus Huntingdoni).

6 to $8 \mathrm{ft}$...

8 to $10 \mathrm{ft}$., $1 \frac{1}{2}$ in. diameter, transplanted.

10 to $12 \mathrm{ft}$., $1 \frac{3}{4}$ to 2 in. diameter, transplanted.

10 to $12 \mathrm{ft}$., 2 to $2 \frac{1}{2}$ in. diameter, transplanted. .

Elm, American (Ulmus Americana).

6 to $8 \mathrm{ft}$., transplanted.

8 to $10 \mathrm{ft}$, $1 \frac{1}{4}$ to $1 \frac{1}{2}$ in. diameter, transplanted .

10 to $12 \mathrm{ft}$., $1 \frac{1}{2}$ to 2 in. diameter, transplanted ..

10 to $12 \mathrm{ft}$., 2 to $2 \frac{1}{2} \mathrm{in}$. diameter, transplanted .

12 to $14 \mathrm{ft}$., $2 \frac{1}{2}$ to $3 \mathrm{in}$. diameter, transplanted . .

12 to $14 \mathrm{ft} ., 3$ in. diameter, transplanted.

12 to $14 \mathrm{ft}$., $3 \frac{1}{2}$ in. diameter, transplanted.

12 to $14 \mathrm{ft} ., 4 \mathrm{in}$. diameter, transplanted.

14 to $16 \mathrm{ft}$., 5 in. diameter, transplanted.

14 to $16 \mathrm{ft}$., 6 in. diameter, transplanted

Specimen trees.

Elm, Scotch (Ulmuslatifolia). Each $10 \quad 100$ 6 to $8 \mathrm{ft} \ldots \ldots \ldots \ldots \ldots \ldots 100 \quad \$ 900 \$ 8000$

8 to $10 \mathrm{ft} ., 1 \frac{1}{2}$ in. diam., trans. 2001800

10 to $12 \mathrm{ft}$., 2 to $2 \frac{1}{2}$ in. diam-

eter, transplanted...... $400 \quad 3500$

12 to $14 \mathrm{ft} ., 3 \mathrm{in.}$ diam., trans. 7006500

12 to $14 \mathrm{ft}$., 4 in. diam., trans. 120011000

12 to $14 \mathrm{ft} ., 5$ in. diam., trans. 2000

Specimen trees.....\$25 to 5000

Ginkgo, or Maidenhair (Salisburia). Each 10 6 to $8 \mathrm{ft}$., transplanted......... $\$ 125 \$ 1100$ 8 to $10 \mathrm{ft}$., transplanted....... $250 \quad 2300$

10 to $12 \mathrm{ft}$., $1 \frac{1}{2}$ to 2 in. diam., trans. 3002700

Hackberry (Celtis occidentalis). Each $10 \mathbf{1 0 0}$ 6 to $8 \mathrm{ft} . \ldots \ldots \ldots \ldots \ldots \ldots \$ 125 \$ 1000 \$ 9000$ 8 to $10 \mathrm{ft} ., 1 \frac{1}{2}$ in. diam., trans. 250220020000 10 to $12 \mathrm{ft}$., 2 in. diam., trans. 4003500 10 to $12 \mathrm{ft} ., 2 \frac{1}{2}$ in. diam., trans. 7506500

10 to $12 \mathrm{ft}$., 3 in. diam., trans. 10008500

Horse-Chestnut, White (A esculus Hippocastanum).

6 to $7 \mathrm{ft}$., transplanted

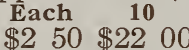

7 to $8 \mathrm{ft}$., transplanted

$\begin{array}{llll}3 & 50 & 32 & 00\end{array}$

8 to $10 \mathrm{ft} ., 1_{\frac{3}{4}}^{3}$ in. diam., trans.... $500 \quad 4500$

10 to $12 \mathrm{ft} ., 2$ to $2 \frac{1}{2}$ in. diam., trans. 800

Specimen trees.

.\$10 to 1500

Horse-Chestnut, Red (Aesculus rubicunda).

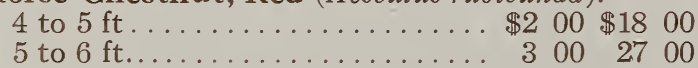

Horse-Chestnut, Ohio Buckeye (Aesculus glabra).

7 to $8 \mathrm{ft}$., transplanted.

$\$ 250 \$ 2200$

8 to $10 \mathrm{ft} ., 1 \frac{3}{4}$ in. diam., trans.... $500 \quad 5500$

10 to $12 \mathrm{ft} ., 2$ to $2 \frac{1}{2}$ in. diam., trans. 800

Specimen trees........\$\$10 to 1500

Kentucky Coffee (Gymnocladus Canadensis).

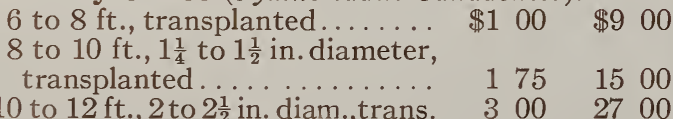

$\begin{array}{rrrr}\$ 1 & 00 & \$ 9 & 00 \\ 1 & 50 & 13 & 00\end{array}$

Each $10 \quad 100$

$\$ 100 \$ 900 \$ 8000$

$\begin{array}{llllll}2 & 00 & 18 & 00 & 170 & 00\end{array}$

$\begin{array}{lllll}3 & 00 & 27 & 00\end{array}$

$\begin{array}{llll}4 & 003500\end{array}$

\begin{tabular}{rrrrrrr}
\multicolumn{2}{c}{ Each } & \multicolumn{10}{c}{$\mathbf{1 0}$} & \multicolumn{100}{c}{$\mathbf{1 0 0}$} \\
$\$ 1$ & 00 & $\$ 9$ & 00 & $\$ 75$ & 00 \\
1 & 50 & 13 & 00 & 100 & 00 \\
2 & 00 & 18 & 00 & 150 & 00 \\
3 & 50 & 32 & 00 & 300 & 00 \\
5 & 00 & 45 & 00 & & \\
6 & 00 & 55 & 00 & & \\
8 & 00 & 75 & 00 & & \\
12 & 00 & 110 & 00 & & \\
20 & 00 & 180 & 00 & & \\
30 & 00 & & & & \\
50 & 00 & & & &
\end{tabular}

$\begin{array}{llllll}\$ 1 & 00 & \$ 9 & 00 & \$ 75 \quad 00\end{array}$

$\begin{array}{llllll}1 & 50 & 13 & 00 & 100 & 00\end{array}$

$\begin{array}{llllll}2 & 00 & 18 & 00 & 150 & 00\end{array}$

$\begin{array}{llllll}3 & 50 & 32 & 00 & 300 & 00\end{array}$

$00 \quad 4500$

$\begin{array}{llll}6 & 00 & 5500\end{array}$

$800 \quad 7500$

3000

30 to 5000

Larch, European

(Larix Europaea).

2 to $3 \mathrm{ft}$.

3 to $4 \mathrm{ft}$., transplanted.

5 to $6 \mathrm{ft}$., transplanted.

6 to $8 \mathrm{ft}$., transplanted Specimens 500

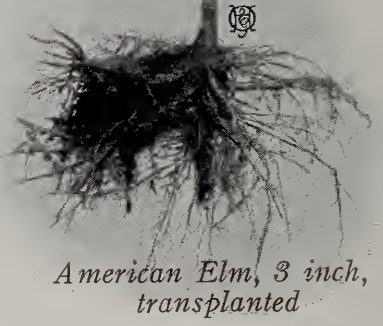

arch, Japan (Larix Kaempferi).

3 to $4 \mathrm{ft}$., transplanted.

4 to $5 \mathrm{ft}$., transplanted.

\begin{tabular}{rrrr} 
Each & \multicolumn{10}{c}{$\mathbf{1 0}$} \\
$\$ 0$ & 75 & $\$ 7$ & 00 \\
1 & 00 & 9 & 00 \\
3 & 50 & 32 & 00 \\
5 & 00 & &
\end{tabular}

inden, American (Tilia Americana).

6 to $8 \mathrm{ft}$., transplanted.. $\begin{gathered}\text { Each } 125 \\ 10\end{gathered} 100$

8 to $10 \mathrm{ft}$., transplanted $\$ 125 \quad \begin{array}{lllll}\$ 11 & 00 & \$ 100 & 00\end{array}$

10 to $12 \mathrm{ft}$., $1 \frac{1}{2}$ to $1 \frac{3}{4}$ in.

10 to $12 \mathrm{ft}$., 2 to $2 \frac{1}{2}$ in.

10 to $12 \mathrm{ft}, 2 \frac{\mathrm{i}}{2}$ to 3 in. diam., trans........ $600 \quad 5500$ 10 to $12 \mathrm{ft} ., 3$ in. diam., tr. 8007000

10 to $12 \mathrm{ft} ., 4$ in. diam., tr. 130011500

Specimen trees... $\$ 15$ to 4000

Linden, European (Tilia Europaea).

6 to $8 \mathrm{ft} \ldots \ldots \ldots \ldots \ldots \$ 100 \$ 900$

8 to $10 \mathrm{ft} ., 1 \frac{1}{2}$ in. diam., tr. 2502200

10 to $12 \mathrm{ft}, 2 \mathrm{in}$. diam., tr. 4003500

$\$ 8000$

20000

10 to $12 \mathrm{ft} ., 3$ in. diam., tr. 10009000

Specimen trees....\$15 to 2500

Locust, Black (Robinia Pseudacacia). Each

6 to $8 \mathrm{ft} \ldots \ldots \ldots \ldots \ldots \ldots \ldots \ldots$

8 to $10 \mathrm{ft}$. , transplanted.

10

$\$ 700$

$\begin{array}{ll}\$ 7 & 00 \\ 13 & 00\end{array}$

Maple, Ash-leaved (Acer Negundo).

6 to $8 \mathrm{ft}$

Each $10 \quad 100$

$\$$ to $8 \mathrm{ft} \ldots \ldots \ldots \ldots \ldots \ldots 075 \$ 700 \$ 50 \quad 00$

$\begin{array}{rrrrrrr}8 \text { to } 10 \mathrm{ft} ., \text { transplanted ... } & 1 & 00 & 9 & 00 & 80 & 00 \\ 10 \text { to } 12 \mathrm{ft} ., 1 \frac{1}{2} \text { in. diam., trans. } & 1 & 50 & 13 & 00 & 100 & 00\end{array}$

10 to $12 \mathrm{ft}, 2$ in. diam., trans. 3002700

10 to $12 \mathrm{ft} ., 3 \mathrm{in}$. diam., trans. 5004500

12 to $14 \mathrm{ft}$., 4 in. diam., trans. 7506500 


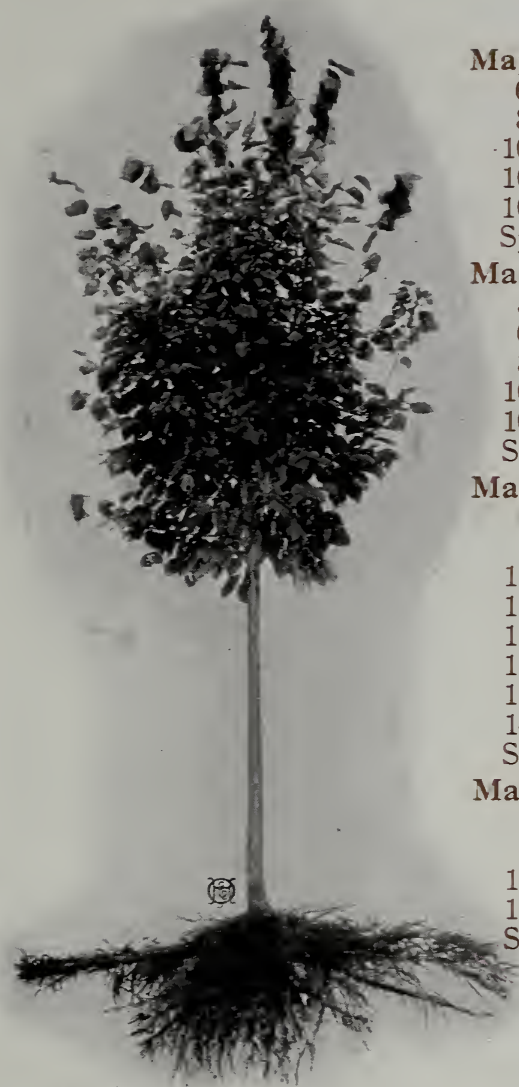

American Linden. 3 inch, transplanted
Maple Norway (Acer platanoides).

6 to $8 \mathrm{ft}$.

8 to $10 \mathrm{ft}$., transplanted.

10 to $12 \mathrm{ft}$., $1 \frac{1}{2}$ in. diameter, transplanted 10 to $12 \mathrm{ft}$., 2 in. diameter, transplanted 10 to $12 \mathrm{ft}$., 3 in. diameter, transplanted Specimen trees.

Taple, Schwedler's (Acer platanoides Schwedleri). 5 to $6 \mathrm{ft}$., transplanted

6 to $8 \mathrm{ft}$., transplanted

8 to $10 \mathrm{ft}$., transplanted.

10 to $12 \mathrm{ft}$., $1 \frac{1}{2}$ in. diameter, transplanted

10 to $12 \mathrm{ft} ., 2$ in. diameter, transplanted.

Specimen trees. .

Maple, Silver (Acer dasycarpum).

6 to $8 \mathrm{ft}$

8 to $10 \mathrm{ft}$., transplanted.

10 to $12 \mathrm{ft}$., $1 \frac{1}{2}$ in. diameter, transplanted.

10 to $12 \mathrm{ft} ., 2$ in. diameter, transplanted.

10 to $12 \mathrm{ft}$., $2 \frac{1}{2}$ in. diameter, transplanted

12 to $14 \mathrm{ft}$., 3 in. diameter, transplanted.

12 to $14 \mathrm{ft} ., 4$ in. diameter, transplanted

14 to $16 \mathrm{ft} ., 5$ in. diameter, transplanted. Specimen trees.

Maple, Sugar (Acer saccharum).

6 to $8 \mathrm{ft}$

8 to $10 \mathrm{ft}$., transplanted.

10 to $12 \mathrm{ft}$., $1 \frac{1}{2}$ in. diameter, transplanted

10 to $12 \mathrm{ft} ., 2$ in. diameter, transplanted.

Maple, Tartarian (Acer Tataricum Ginnala).

2 to $3 \mathrm{ft}$

3 to $4 \mathrm{ft}$., bushy, transplanted

4 to $5 \mathrm{ft}$., bushy, transplanted

5 to $6 \mathrm{ft}$., bushy, transplanted

5 to $6 \mathrm{ft}$., tree form, transplanted.

6 to $8 \mathrm{ft}$., tree form, transplanted
Each $\quad 10 \quad 100$

$\$ 125 \$ 1100 \$ 9000$

$\begin{array}{lllllll}2 & 00 & 18 & 00 & 150 & 00\end{array}$

$3002800250 \quad 00$

$\begin{array}{llll}4 & 00 & 3500 & 00\end{array}$

$80070 \quad 00$

$\$ 10$ to 2000

$\$ 10$ to

\begin{tabular}{rrrr} 
Each & \multicolumn{1}{c}{10} \\
$\$ 1$ & 50 & $\$ 13$ & 00 \\
2 & 50 & 22 & 00 \\
3 & 50 & 32 & 00 \\
6 & 00 & 55 & 00 \\
8 & 00 & &
\end{tabular}

$\$ 10$ to 2500

Each $10 \quad 100$

\$0 $75 \$ 700 \$ 6000$

$\begin{array}{llllll}1 & 25 & 11 & 00 & 100 & 00\end{array}$

$\begin{array}{llllll}2 & 00 & 18 & 00 & 160 & 00\end{array}$

$\begin{array}{llllll}3 & 00 & 27 & 00 & 225 & 00\end{array}$

4003500

6005500

120010000

2000

$\$ 20$ to 5000

$\$ 100 \$ 900 \$ 8000$

$\begin{array}{llllll}1 & 75 & 15 & 00 & 135 & 00\end{array}$

2502250

$\begin{array}{llll}4 & 00 & 35 & 00\end{array}$

1500
Maple, Wier's (Acer dasycarpum Wieri).

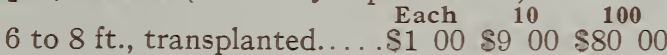

8 to $10 \mathrm{ft}$., transplanted.... $200 \quad 1800 \quad 150 \quad 00$

10 to $12 \mathrm{ft}$., $1 \frac{1}{2}$ in.diam., trans. 300280025000

10 to $12 \mathrm{ft} ., 2$ in. diam., trans. 4003500

12 to $14 \mathrm{ft}$., 3 in. diam., trans. 8007000

Specimen trees....\$7 50 to 2000

Mountain Ash, American (Sorbus Americana).

6 to $8 \mathrm{ft}$., transplanted. .

Each 10

$\ldots \ldots 150 \$ 1300$

10 to $12 \mathrm{ft} ., 2$ to $3 \mathrm{in}$. diameter, trans. $\quad 500 \quad 4500$

Specimen trees.........\$7 to 1000

Mountain Ash, European (Sorbus Aucuparia).

6 to $8 \mathrm{ft}$., transplanted... E $\$ 100 \quad \$ 900 \quad 8800$

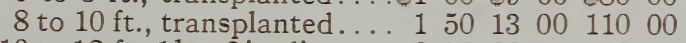

10 to $12 \mathrm{ft} ., 1 \frac{1}{2}$ to 2 in. diam.,tr. 250220020000

10 to $12 \mathrm{ft} ., 2$ in. diam., trans. 4003500

10 to $12 \mathrm{ft}$., $2 \frac{1}{2}$ to 3 in. diam., tr. 6005500

12 to $14 \mathrm{ft} ., 3$ in. diam., trans. 8007500

Specimen trees.....\$ $\$ 10$ to 1500

Mountain Ash, Golden (Sorbus aurea). Each

5 to $6 \mathrm{ft}$., transplanted.

6 to $8 \mathrm{ft}$., transplanted.

$\$ 100 \$ 900$

diam......... 1501300

Specimen trees..........\$5 to 1500

Mountain Ash, Oak-leaved (Sorbus quercifolia).

6 to $8 \mathrm{ft}$., transplanted.... $\$ \$ 150 \$ 1300 \$ 11000$

8 to $10 \mathrm{ft}$., transplanted.... $200 \quad 1800 \quad 20000$

8 to $10 \mathrm{ft} ., 1 \frac{3}{4}$ in. diam., trans. 3002700

8 to $10 \mathrm{ft} ., 2$ in. diam., trans. $500 \quad 4500$

Specimen trees.......\$5 to 1000

Mulberry, Russian (Morus Tatarica). Each

4 to $5 \mathrm{ft}$., transplanted, bushy.... S0 60

5 to $6 \mathrm{ft}$., transplanted, bushy.... 80

6 to $8 \mathrm{ft}$., transplanted, bushy.... 150

Specimen trees.

$\$ 3$ to 600
Oak, Pin (Quercus palustris).

4 to $5 \mathrm{ft}$.

5 to $6 \mathrm{ft}$

8 to $10 \mathrm{ft} ., 1 \frac{1}{2}$ in. diam., trans.

Specimen trees.

\$0 $80 \$ 700 \quad \$ 6000$

$\begin{array}{llllll}1 & 00 & 9 & 00 & 80 & 00\end{array}$

$\begin{array}{llllll}2 & 00 & 18 & 00 & 160 & 00\end{array}$

$\begin{array}{llll}3 & 50 & 32 & 00\end{array}$

3002800

4002500

Each 10

$\$ 125 \$ 1100$

$200 \quad 1800$

$500 \quad 4500$

Oak, Scarlet (Quercus coccinea).

4 to $5 \mathrm{ft}$.

$\$ 125 \$ 1100$

5 to $6 \mathrm{ft}$

$200 \quad 1800$

8 to $10 \mathrm{ft} ., 1 \frac{1}{2}$ in. diam., trans.

Specimen trees.

$500 \quad 4500$

Oak, White (Quercus alba).

4 to $5 \mathrm{ft}$., transplanted

5 to $6 \mathrm{ft}$., transplanted

$\$ 125 \$ 1100$

$\begin{array}{llll}2 & 00 & 18 & 00\end{array}$

8 to $10 \mathrm{ft} ., 1 \frac{1}{2}$ in. diam., trans..... 5 004500

Specimen trees..........\$5 to 1000

Plum, Double-flowering (Prunus triloba)

2 to $3 \mathrm{ft} \ldots \ldots \ldots \ldots \ldots \ldots$.......... s0 60

3 to $4 \mathrm{ft}$., transplanted

4 to $5 \mathrm{ft}$., transplanted.

Specimen trees.

$\$ 500$

$\begin{array}{llll}125 & 10 & 00\end{array}$

$200 \quad 1800$

Poplar, Balsam, Balm of Gilead (Populus balsamifera).

10 to $12 \mathrm{ft} ., 1 \frac{1}{2}$ in. diam., trans. $\$ 150 \$ 1300 \$ 11000$

10 to $12 \mathrm{ft} ., 2$ in. diam., trans. 250220020000

10 to $12 \mathrm{ft} ., 2 \frac{1}{2}$ in.diam., trans. 3002700

Specimen trees ......S5 to 750

Poplar, Bolleana (Populus alba, var. Bolleana).

6 to $8 \mathrm{ft} \ldots \ldots \ldots \ldots \ldots . \$ 100 \$ 900 \$ 8000$

8 to $10 \mathrm{ft}$., transplanted.... $1150 \quad 13 \quad 0011000$

10 to $12 \mathrm{ft}$., $1 \frac{1}{2}$ in. diam., trans. 250220020000

10 to $12 \mathrm{ft} ., 2$ in. diam., trans. 5004500

12 to $14 \mathrm{ft} ., 2 \frac{1}{2}$ in. diam.,trans. 7006500

12 to $14 \mathrm{ft} ., 3$ in. diam., trans. 9008500

Specimen trees.....\$ 10 to 1500

Poplar, Carolina (Populus monilifera).

6 to $8 \mathrm{ft}$., transplanted... \$0 $80 \quad \$ 700 \$ 60 \quad 00$

8 to $10 \mathrm{ft}$., transplanted. . $100 \quad 900 \quad 7000$

10 to $12 \mathrm{ft} ., 1 \frac{1}{2}$ in.diam.,trans. 125110010000 


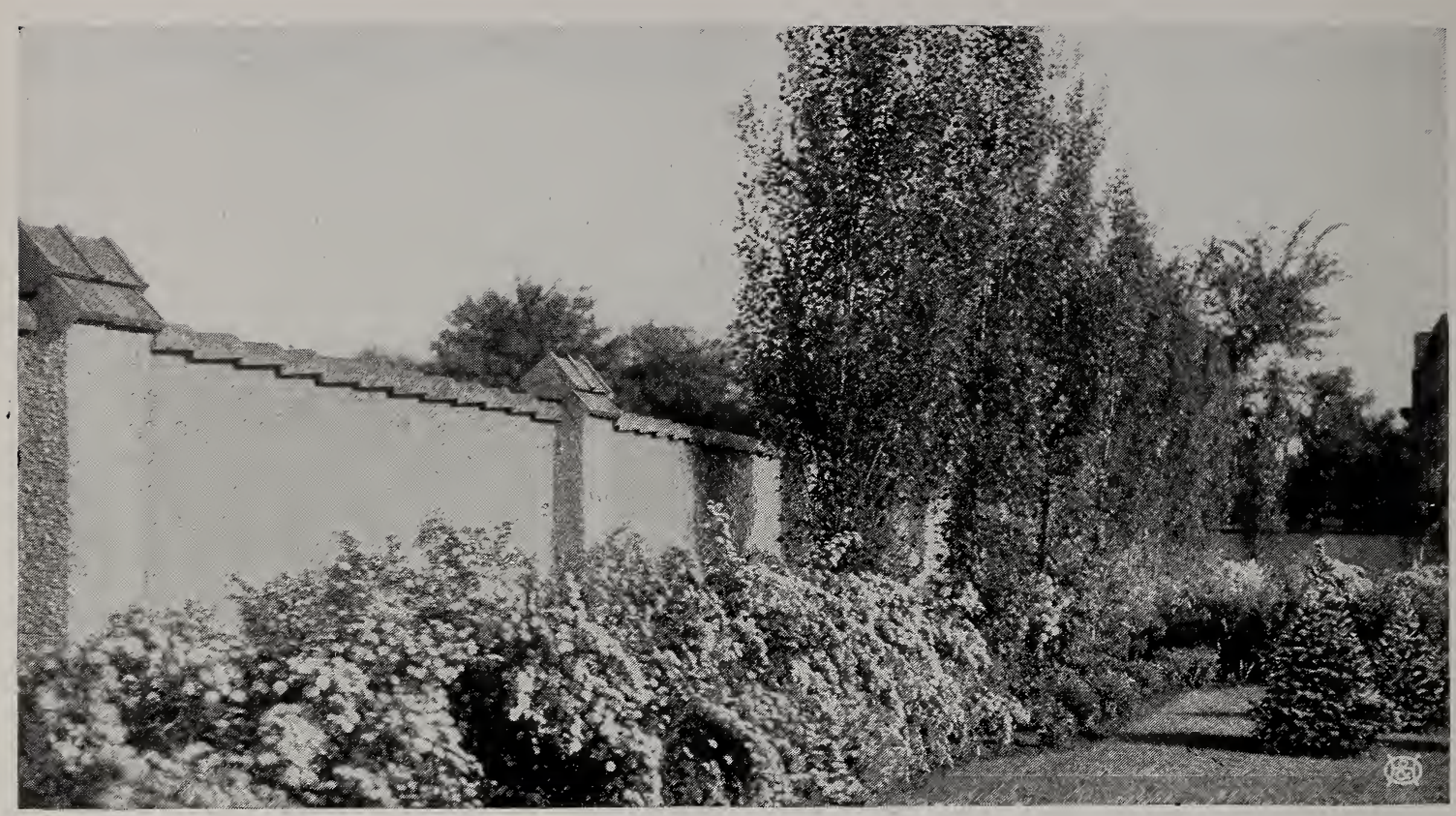

Showing a practical use of Lombardy Poplars to screen unsightly objects

Poplar, Carolina-Continued. Each $10 \quad 100$ 10 to $12 \mathrm{ft} ., 2$ in.diam.,trans. $\$ 200 \$ 1800 \$ 15000$

10 to $12 \mathrm{ft} ., 2 \frac{1}{2}$ in. diam., trans. 3002700

12 to $14 \mathrm{ft} ., 3$ in. diam., trans. 5004500

12 to $14 \mathrm{ft}$., 4 in. diam., trans. 7506500

Specimen trees.....\$6 to 1000

Poplar, Lombardy (Populus fastigiata).

6 to $8 \mathrm{ft}$

$\$ 0 \quad 80 \$ 7 \quad 00 \$ 6000$

8 to $10 \mathrm{ft}$., transplanted.

$\begin{array}{lllllll}1 & 50 & 12 & 00 & 100 & 00\end{array}$

10 to $12 \mathrm{ft} ., 1 \frac{1}{2}$ in.diam., trans. 250220020000

10 to $12 \mathrm{ft} ., 2$ in. diam., trans. 400350032500

12 to $14 \mathrm{ft} ., 2 \frac{1}{2} \mathrm{in}$.diam., trans. 5004500

12 to $14 \mathrm{ft}$., 3 in.diam., trans. 8007500

Specimen trees......\$8 to 1000

Poplar, Norway (Populus certinensis).

6 to $8 \mathrm{ft} .$, transplanted... $\$ 080 \$ 700 \$ 6000$

8 to $10 \mathrm{ft}$., transplanted.. $100 \quad 900 \quad 8000$

10 to $12 \mathrm{ft} ., 1 \frac{1}{2}$ in.diam.,trans. 150130011000

12 to $14 \mathrm{ft} ., 2$ in.diam.,trans. 250225020000

12 to $14 \mathrm{ft} ., 2 \frac{1}{2}$ in. diam., trans. 3503000

12 to $14 \mathrm{ft} ., 3$ in. diam.,trans. 5004500

Specimen trees......\$5 to 1000

Poplar, Silver (Populus alba).

6 to $8 \mathrm{ft}$., transplanted

8 to $10 \mathrm{ft}$., transplanted

1300

Specimen trees.........\$5 to 750
Sumac, Smooth (Rhus glabra).

4 to $5 \mathrm{ft}$. . .

5 to $6 \mathrm{ft}$., transplanted

6 to $8 \mathrm{ft}$., transplanted

Specimen trees.

Sumac, Cut-leaved (Rhus typhina)

3 to $4 \mathrm{ft}$., transplanted

4 to $5 \mathrm{ft}$., transplanted

Specimen trees

Each 10

$\$ 060 \$ 500$

80700

1501300

(Juglans nigra). Each 10100 5 to $6 \mathrm{ft} . . . \ldots \ldots \ldots \ldots \ldots . \$ 060 \$ 500 \$ 4000$ 6 to $8 \mathrm{ft}$. , transplanted................... $100 \quad 900 \quad 8000$ 8 to $10 \mathrm{ft}$., transplanted.... 1501300

Willow, Golden (Salix vitellina aurea).

6 to $8 \mathrm{ft} .$, transplanted... . $\$ 0 \quad 80 \$ 700 \$ 5000$

8 to $10 \mathrm{ft}$. , transplanted... $\quad \begin{array}{llllll} & 00 & 9 & 00 & 80 & 00\end{array}$

10 to $12 \mathrm{ft} ., 1 \frac{1}{2}$ in. diam., trans. 200180016500

10 to $12 \mathrm{ft} ., 2 \mathrm{in}$. diam., trans. 3002700

Specimen trees......\$4 to 800

Willow, Laurel (Salix pentandra).

6 to $8 \mathrm{ft} . \ldots \ldots \ldots \ldots \ldots \ldots \$ 0 \quad 80 \$ 700 \$ 5000$

8 to $10 \mathrm{ft}$. , transplanted.... $\quad 100 \quad 900 \quad 8000$

10 to $12 \mathrm{ft.}, 1 \frac{1}{2}$ in. diam., trans. $200 \quad 1800 \quad 16500$

10 to $12 \mathrm{ft} ., 2$ in. diam.,trans. 3002700

Specimen trees. $\$ 4$ to 800

Willow, Niobe (Salix Niobe).

6 to $8 \mathrm{ft}$., transplanted.... \$1 25\$1100\$100 00

8 to $10 \mathrm{ft}$., transplanted... $200 \quad 1800 \quad 16500$

10 to $12 \mathrm{ft}$., transplanted... 3002700

Specimen trees......\$5 to 2500

\section{WEEPING TREES}

$\mathrm{T}$

REES of this class are not mournful, as the expression would seem to imply, but the tendency of their growth is drooping. Trees of their habit are great acquisitions to the ornamentals. Certain characteristics about them are very striking and make them attractive; they are interesting from their oddity, and indispensable for landscape effects.

Birch, Cut-leaved Weeping (Betula laciniata pendula).

5 to $6 \mathrm{ft}$.

Each $10 \quad 100$

6 to $7 \mathrm{ft}$

$\$ 150 \$ 1300 \$ 10000$

7 to $8 \mathrm{ft}$

$\begin{array}{llllllll}2 & 00 & 18 & 00 & 150 & 00\end{array}$

7 to $8 \mathrm{ft}$., transplanted..... 3503300

8 to $10 \mathrm{ft}$., transplanted... 5004500

8 to $10 \mathrm{ft} ., 1 \frac{1}{2}$ in. diam., trans. 8007500

Specimen trees..... \$10 to 2500

Elm, Camperdown (Ulmus pendula).

$\$ 300 \$ 2500$

3 -yr. heads............... $400 \quad 3500$
Elm, Camperdown-Continued.

Specimen trees, budded, Each 10 and $12 \mathrm{ft} . . \ldots \ldots \ldots \ldots \$ 10$ to $\$ 2000$

Mountain Ash, Weeping (Sorbus Aucuparia pendula).

Each $\quad 10$

2 -yr. heads................. \$2 $00 \$ 1800$

3 -yr. heads, transplanted........ $300 \quad 2700$

Specimen trees..........\$5 to 1000

Mulberry, Teas' Weeping (Morus tatarica pendula).

2-yr. heads................ \$3 $00 \$ 2500$

3 -yr. heads..................... $400 \quad 3500$

Specimen trees...........\$5 to 1000 


\section{EVERGREENS}

B

EAUTIFUL groupings can be made by carefully selecting such varieties as go well together; but one must know the habit of growth and be able to contrast the different foliage so that the real beauty will stand out. Only in recent years have we begun to discover new uses for evergreens, and no longer are these trees used only for screens or classed as fit only for cemeteries.

They furnish backgrounds for flowering shrubs; and the winter landscape is not complete without the cheerful colors of the various shades of the evergreens.

Our evergreens are given special care, handled carefully and transplanted frequently, so there is no danger in moving them from our nurseries. Each tree is planted so that it grows symmetrically and develops into a shapely specimen. All evergreens are priced balled with earth and wrapped in burlap, so that they reach customers in good condition.

Arborvitae, American (Thuya occidentalis).

$2 \mathrm{ft}$., transplanted.

$3 \mathrm{ft}$., transplanted.

$4 \mathrm{ft}$., transplanted.

$5 \mathrm{ft} .$, transplanted.

$6 \mathrm{ft}$., transplanted.

Specimen trees.
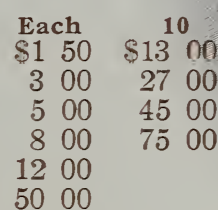

$\$ 15$ to 5000

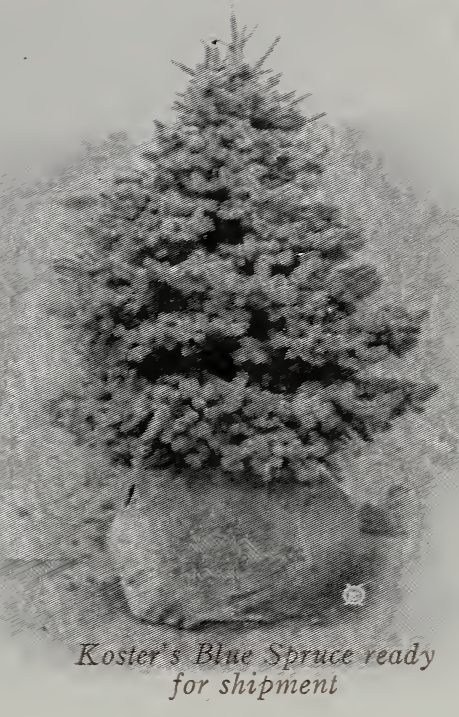

Arborvitae, Compact (Thuya compacta).

Dwarf

$2 \mathrm{ft}$. , transplanted

$2 \frac{1}{2} \mathrm{ft}$., transplanted

\begin{tabular}{|c|c|c|c|c|}
\hline \multicolumn{4}{|l|}{ 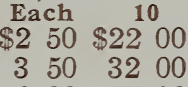 } & 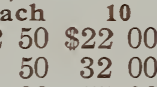 \\
\hline
\end{tabular}

Arborvitae, Pyramidal (Thuya pyramidalis)

$3 \mathrm{ft}$., transplanted.

2 to $3 \mathrm{ft}$., transplanted

Each 10

$3 \mathrm{ft}$., transplanted.

$\$ 300 \$ 2500$

$4 \mathrm{ft}$., transplanted

4504000

$5 \mathrm{ft}$., transplanted

$600 \quad 5500$

Arborvitae, Douglas Golden (Thuya Douglasii aurea).

$2 \mathrm{ft}$. , transplanted

$3 \mathrm{ft}$., transplanted

$\$ 300 \$ 2700$

$4 \mathrm{ft}$., transplanted.

$\begin{array}{llll}500 & 4500\end{array}$

800

Arborvitae, Globe (Thuya globosa). Very dwarf.

15 to 18 in., transplanted.

18 to 24 in., transplanted.

$\$ 300 \$ 2500$

Specimen trees.

$600 \quad 5500$

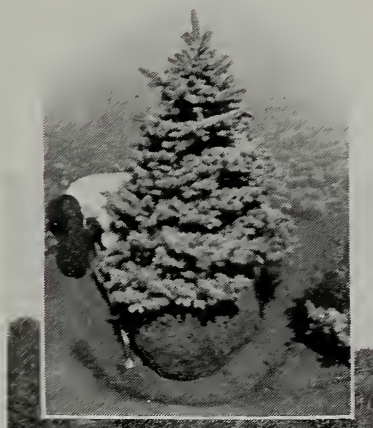

$\$ 750$ to 1500

$6 \mathrm{ft} .$, transplanted

1000

- 1500

$8 \mathrm{ft}$., transplanted.............. 2500

Specimen trees.

$\$ 25$ to 5000

Arborvitae, Rivers' (Thuya"Riversii).

$2 \mathrm{ft}$., transplanted
$3 \mathrm{ft}$., transplanted
$4 \mathrm{ft}$., transplanted

Arborvitae, Rosenthal's (Thuya pyramidalis Rosenthalii).

$2 \mathrm{ft}$. , transplanted......

$3 \mathrm{ft}$., transplanted.

$4 \mathrm{ft}$. , transplanted

$5 \mathrm{ft}$., transplanted.

Specimen trees.

Each 10

$\$ 350 \$ 3200$

$\begin{array}{llll}6 & 00 & 55 & 00\end{array}$

1200

1500

$\$ 10$ to 2000

H. \& O. Evergreens are all shipped with balls of earth wrapped in burlap-they reach you in a growing condition.

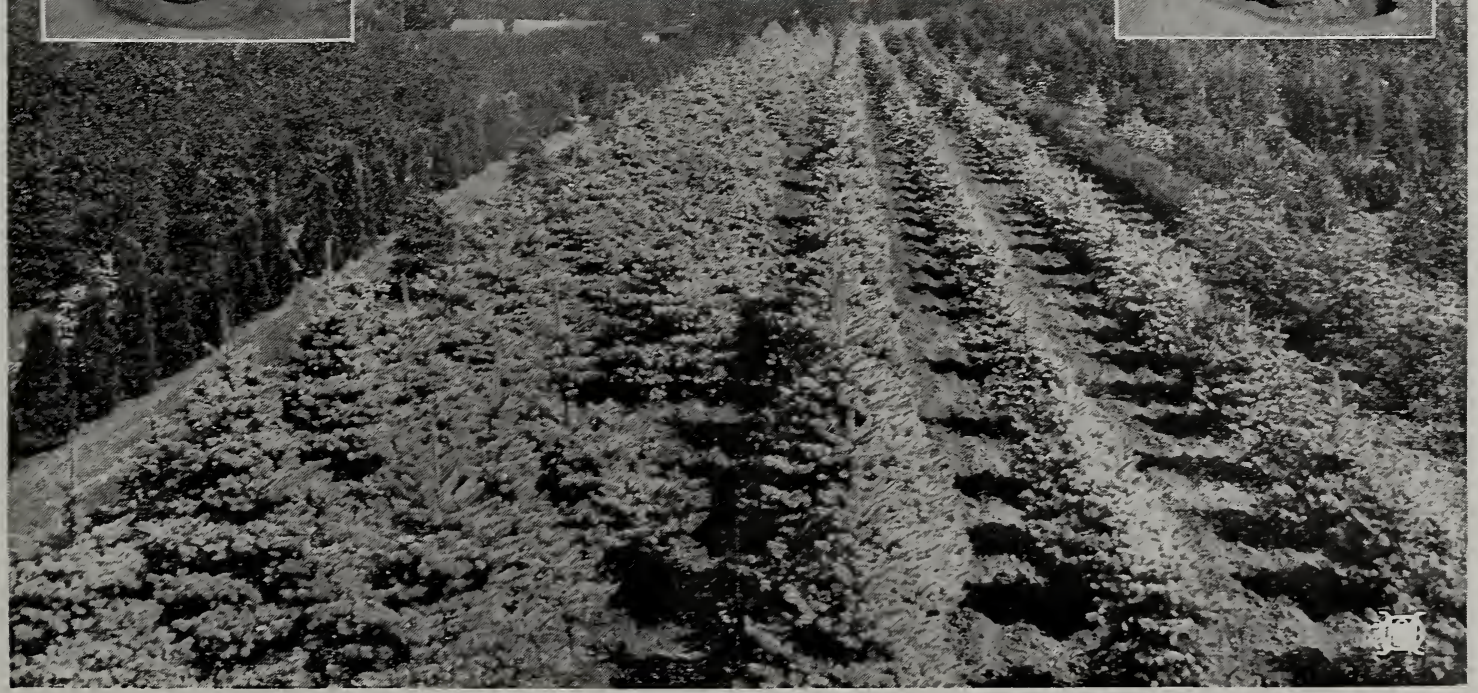

A block of Koster's Blue Spruce from 5 to 8 feet high. Note that "H. \& O." quality, and the manner in which they are made ready to ship 


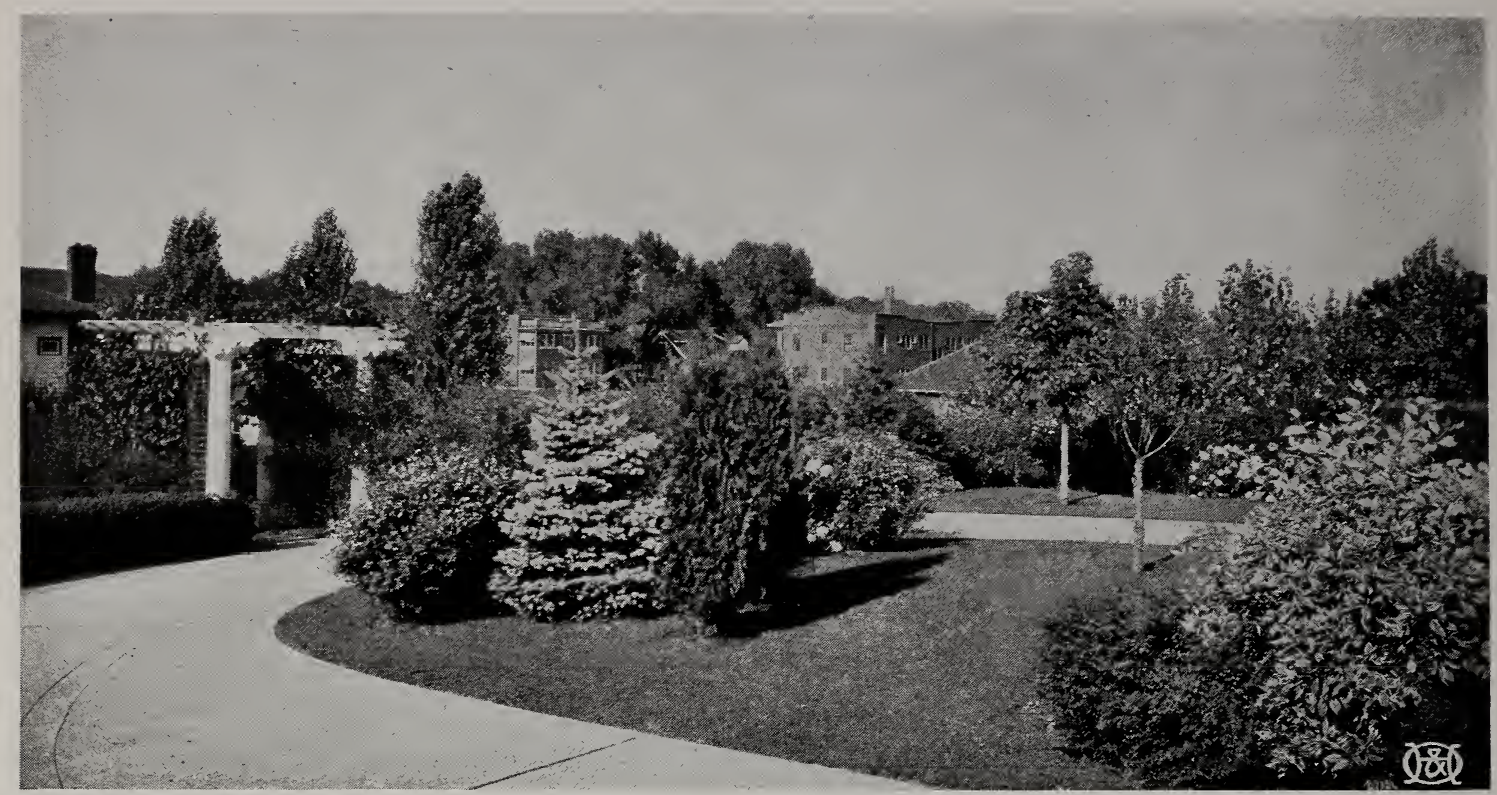

A group of Evergreens that give dignity and distinction to your grounds

Arborvitae, Siberian (Thuya Wareana Sibirica). 2 ft., transplanted........... $\$ 350 \$ 3000$ $3 \mathrm{ft}$., transplanted.

$600 \quad 5500$ rborvitae, Siberian (Thuya Sibirica).

18 in., transplanted...........\$2 $50 \$ 2200$

$2 \mathrm{ft}$. , transplanted

Fir, Balsam (Abies balsamea).

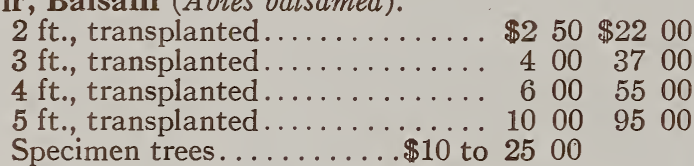

Specimen trees..........\$10 to 2500

Fir, Double Balsam (Abies Fraseri).

$3 \mathrm{ft}$, transplanted............\$5 $00 \$ 4500$

$4 \mathrm{ft}$., transplanted............ $700 \quad 6500$

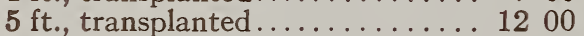

$6 \mathrm{ft}$. , transplanted............ 2000

Fir, Douglas' (Abies Douglasii).
$2 \mathrm{ft}$., transplanted
$3 \mathrm{ft}$. , transplanted
$\$ 300 \$ 2800$
$4 \mathrm{ft}$., transplanted
$500 \quad 4500$
$800 \quad 7500$

Fir, Nikko (Abies brachyphylla).

$2 \mathrm{ft}$., transplanted............ \$4 $00 \$ 3500$

$3 \mathrm{ft}$., transplanted............ $500 \quad 4500$

Fir, White (Abies concolor).

2 ft., transplanted............\$5 $00 \$ 4500$

$3 \mathrm{ft}$., transplanted............. 8007500

$4 \mathrm{ft}$., transplanted............... 150012000

Specimen trees..........\$20 to 7500

Juniper, Glauca (Juniperus Virginiana glauca).

2 ft., transplanted, bushy........\$4 $50 \$ 4000$

$3 \mathrm{ft}$. , transplanted, bushy....... $600 \quad 5500$

$4 \mathrm{ft}$., transplanted, bushy........ 10009500

5 ft., transplanted, bushy ........ 1500

Specimen trees.........\$20 to 3000

Juniper, Golden (Juniperus Chinensis aurea)

$2 \mathrm{ft}$., transplanted............\$500\$4700

$3 \mathrm{ft}$., transplanted............ $700 \quad 6500$

Specimen trees.......... $\$ 10$ to 1500

Juniper, Savin (Juniperus Sabina).

18 in., transplanted.

$2 \mathrm{ft}$. , transplanted.

$\$ 350 \$ 3000$

Specimen trees.

500
4500

$\$ 10$ to 2000

Juniper, Schott's (Juniperus Virginiana Schottii).

$2 \mathrm{ft}$., transplanted............\$4 $00 \$ 3700$

$3 \mathrm{ft}$. , transplanted............... 6 6 $00 \quad 5500$

$4 \mathrm{ft}$. , transplanted............. $800 \quad 7500$
Juniper, Schott's-Continued. Each 10 $5 \mathrm{ft}$., transplanted........... \$1500 $\$ 12500$ Specimen trees........\$15 to 2500

Juniper, Pfitzer's (Juniperus Pfitzeriana). $2 \mathrm{ft}$. , transplanted............\$4 $00 \$ 3700$

$3 \mathrm{ft}$., transplanted............. $600 \quad 5500$

$4 \mathrm{ft}$. , transplanted............ 900

$5 \mathrm{ft}$., transplanted .............. 1500

$6 \mathrm{ft}$. , transplanted............ 2000

Specimen trees.........\$20 to 2500

Juniper, White, or Red Cedar (Juniperus Virginiana)

$2 \mathrm{ft}$., transplanted............ \$2 $50 \$ 2200$

$3 \mathrm{ft}$., transplanted........... $400 \quad 3500$

$4 \mathrm{ft}$., transplanted............. $700 \quad 6500$

$5 \mathrm{ft}$., transplanted.............. $1000 \quad 9000$

$6 \mathrm{ft}$, transplanted............. 170015000

$7 \mathrm{ft}$. , transplanted............... 2500

Specimen trees.........\$25 to 5000

Juniper, Swedish (Juniperus Suecica).

$2 \mathrm{ft}$. , transplanted............ \$5 $00 \$ 4500$

Juniper, Trailing (Juniperus procumbens).

18 in. spread, transplanted...... \$3 $50 \$ 3200$

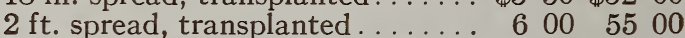

Specimen trees........\$10 to 2000

Pine, Dwarf Mugho ( Pinus Mughus). A unique Alpine species, broader than its height and sometimes almost prostrate, forming a dark, domeshaped bush, 5 to 8 feet high. Used for planting on rocky banks, terrace slopes, small lawns, and particularly effective when grown at the corners of entrances, either singly or in company with other evergreens.

12 in., transplanted........... \$3 $00 \$ 2800$

18 in., transplanted........... $400 \quad 3700$

24 in., transplanted........... $700 \quad 6500$

Specimen trees.........\$10 to 2000

Pine, Swiss Stone ( Pinus Cembra).

$3 \mathrm{ft} .$, transplanted ........... \$10 00

$4 \mathrm{ft}$. , transplanted............ 1500

$5 \mathrm{ft}$., transplanted ................ 2000

Specimen trees..........\$20 to 2500

Note.-Owing to the presence of White Pine Blister in the eastern sections of the United States, we have concluded not to offer the five-fingered Pines in our Catalogue. We have a quantity now, but will stop growing them for the present. 


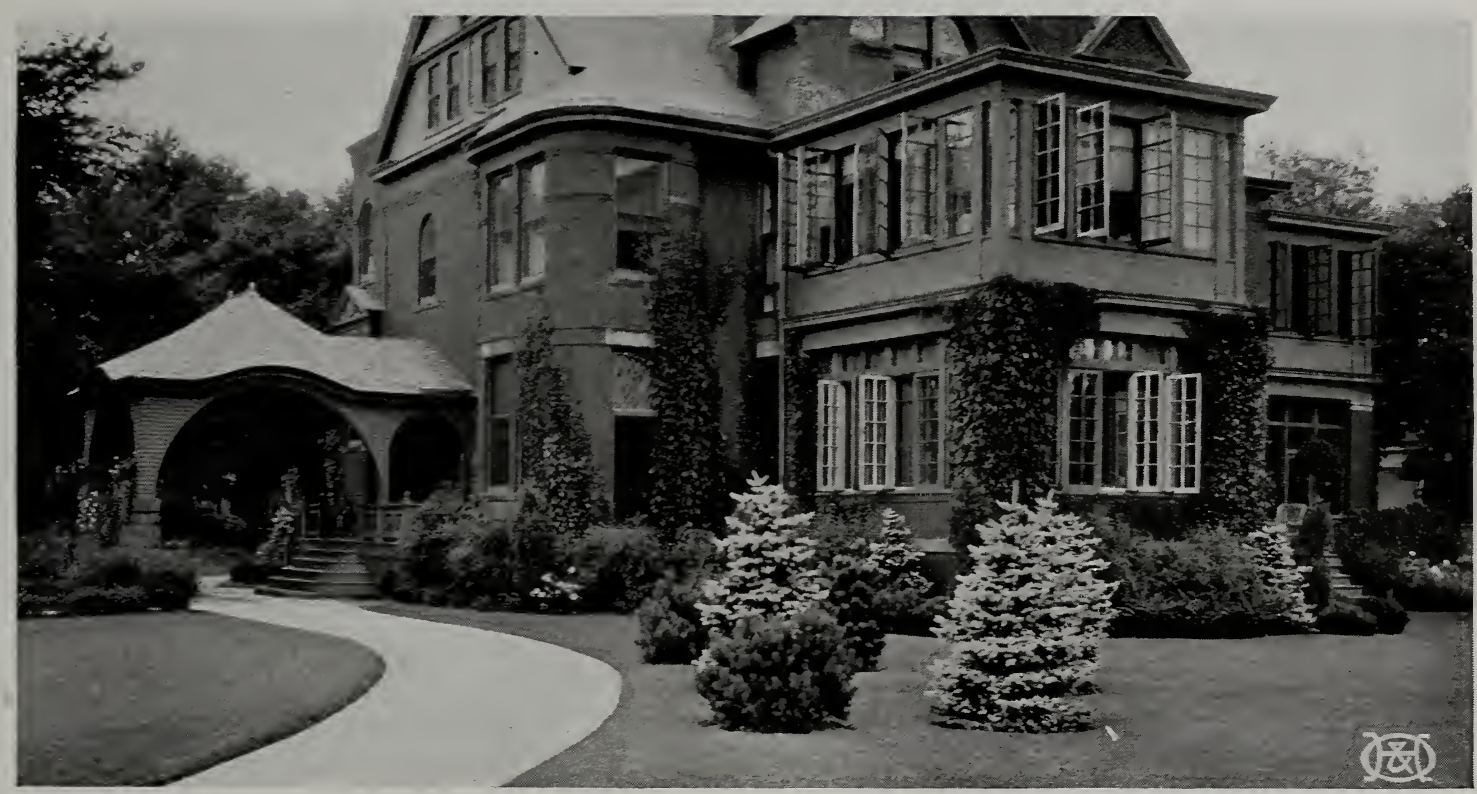

Plantings that are so much admired are results of the knowledge of trees and plants possessed by the $H$. E $O$. seriice

Spruce, Colorado Blue (Picea pungens).

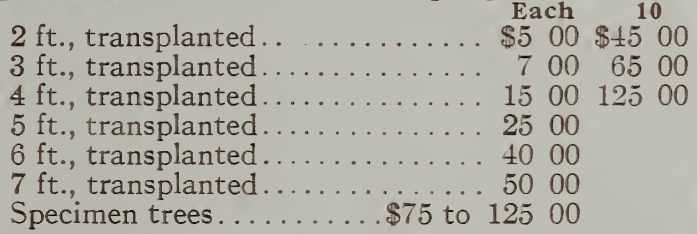

Spruce, Koster's Colorado Blue (Picea pungens Kosteriana). The best and most attractive of the Blue Spruces. Foliage a silvery blue, densely crowded on the many branches. Our blocks of this variety are a sight to behold; they show distinction and quality.

$2 \mathrm{ft}$., transplanted.

$2 \frac{1}{2} \mathrm{ft}$., transplanted.

$3 \mathrm{ft}$., transplanted.

$3 \frac{1}{2} \mathrm{ft}$., transplanted.

$4 \mathrm{ft}$. , transplanted.

$4 \frac{1}{2} \mathrm{ft}$., transplanted.

$5 \mathrm{ft}$., transplanted.

$5 \frac{1}{2} \mathrm{ft}$., transplanted.

$6 \mathrm{ft}$., transplanted.

Specimen trees.

$\$ 750 \$ 7000$

$\begin{array}{lll}10 & 00 \quad 90 & 00\end{array}$

$\begin{array}{llll}15 & 00 & 130 & 00\end{array}$

2000

2500

3000

3500

4000

5000

$\$ 75$ to 15000

Spruce, Black Hills (Picea Canadensis).

18 in., transplanted........... \$2 $50 \$ 2200$

$2 \mathrm{ft}$., transplanted............ $\pm 00 \quad 3700$

$3 \mathrm{ft}$., transplanted............ $700 \quad 6500$

$4 \mathrm{ft}$., transplanted............. 1500

Specimen trees.......... $\$ 20$ to 5000

Spruce, Engelmann's (Picea Engelmanni).

$2 \mathrm{ft}$., transplanted............. \$5 $00 \$ 4500$

$3 \mathrm{ft}$., transplanted............... $700 \quad 6500$

$4 \mathrm{ft}$., transplanted............ 1500

$5 \mathrm{ft}$., transplanted.............. 2500

Specimen trees.........\$30 to 4000

Spruce, Hemlock (Tsuga Canadensis).

18 in.................... \$1 $50 \$ 1200$

2 ft., transplanted................ $250 \quad 50 \quad 2300$

$3 \mathrm{ft}$, transplanted............ $450 \quad 4200$

$4 \mathrm{ft}$., (Select).................. 7507000

$5 \mathrm{ft}$. , (Select).............. 1200

$6 \mathrm{ft}$. , (Select)................... 2000
Spruce, Omorika (Picea Omorika). Each

$6 \mathrm{ft}$., transplanted........... \$10 00

$7 \mathrm{ft}$., transplanted............ 1500

Specimen trees..........\$15 to 2000

Spruce, Douglas (Pseudotsuga Douglasii).

$2 \mathrm{ft}$., transplanted............. \$3 $50 \$ 3200$

$3 \mathrm{ft}$. , transplanted.

$500 \quad 4500$

Spruce, Doumett's Black (Piced nigra Doumetti). $2 \mathrm{ft}$., transplanted...

$3 \mathrm{ft} .$, transplanted....

$\$ 600 \$ 5500$

Specimen trees.........\$10 to 1500

Spruce, Norway (Picea excelsa).

$2 \mathrm{ft}$., transplanted....

ft. transplanted........... \$2 $00 \$ 1800$

$4 \mathrm{ft}$, transplanted............ $600 \quad 5500$

5 ft., (Select)............... 1000

$6 \mathrm{ft}$. , (Select)............... 1500

Specimen trees.........\$15 to 2500

Spruce, White (Picea alba).

18 in., transplanted.

$2 \mathrm{ft}$., transplanted.

$3 \mathrm{ft}$, transplanted.......... $500 \quad 4500$

$4 \mathrm{ft}$., (Select)................ 700

5 ft., (Select)............. 1000

Specimen trees.........\$15 to 5000

Yew, Canadian (Taxus Canadensis).

12 in., transplanted........... 15 in., transplanted......... $50 \$ 400 \quad 3800$

18 in., transplanted.......... $500 \quad 4500$

Yew, Japanese (Taxus cuspidata brevifolia).

12 in., transplanted. . . . . . . . . \$2 $00 \$ 1800$

15 in., transplanted.......... $400 \quad 3700$

18 in., transplanted...........6 $600 \quad 5500$

Yew, Spreading (Taxus repandens).

12 in., transplanted............ \$2 $50 \$ 2200$

15 in., transplanted........... $400 \quad 3500$

18 in., transplanted...............6 $600 \quad 5500$ 


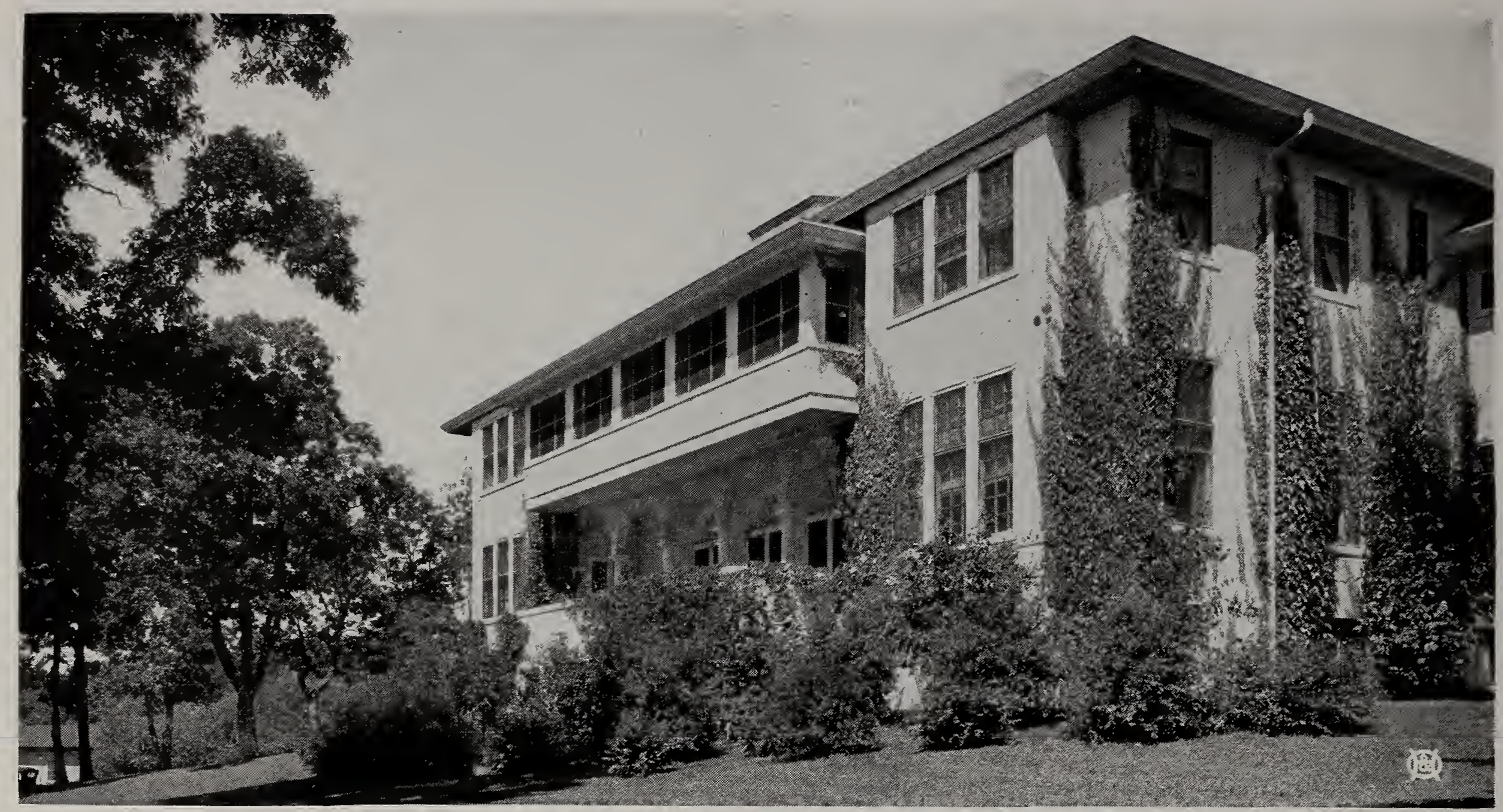

The home of Mr. A. H. Stem, Dellwood, White Bear Lake

\section{DECIDUOUS SHRUBS}

I T MATTERS NOT whether planted singly or collectively, the shrub is the important factor in the adornment of any grounds. The study of the intelligent use of these by the landscape gardener, and the fact that people desire to live more away from the center of business, has caused the steady increase and the greater development in the art of planting. A certain location often suggests a particular shrub, which, by its habit of growth or color of flower, becomes a distinguishing feature of the planting. When this is the case, varieties that develop into symmetrical shape should be used. In many locations their gracefulness and beauty are greatly admired.

Nursery-row Shrubs. We are asked how they differ from other shrubs. Nursery-row shrubs are those that are planted 6 to 8 inches apart in the row when they come from the seedling or cutting bed. They have one, two and three stems, just what you get from other nurseries.

Transplanted Shrubs. These are the nursery-row plants dug and transplanted into rows, set $1 \frac{1}{2}$ to 2 feet apart, and cut back so they may make a bushy top and a good root-system. It takes two years additional to accomplish this, but we get a plant of more than double value. They transplant with much less loss, and give a great deal better satisfaction. Ask any of our patrons.

Specimen Shrubs. These are large, fully developed plants that give results from the time they are planted. They are moved from time to time, and can be taken up with a ball of earth the same as evergreens. We can supply these in all sizes of most varieties. They range in price from $\$ 1.50$ to $\$ 7.50$ each.

When orders amount to $\$ 25$ or more, shrubs will be furnished at the ten rate, or five shrubs for half the price given for ten. Write for prices on large quantities, giving size and number of each. We have the largest collection of specimen shrubs in the country.

Almond, Double White (Amygdalus alba).

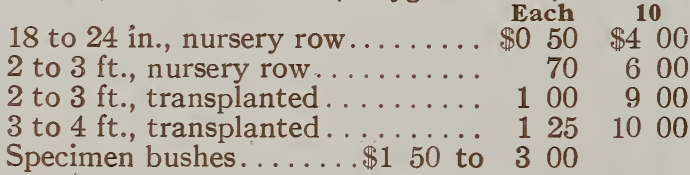

Almond, Double Pink (Amygdalus rosea).

18 to 24 in., nursery row........\$0 50

2 to $3 \mathrm{ft}$., nursery row

2 to $3 \mathrm{ft} .$, transplanted

3 to $4 \mathrm{ft}$., transplanted

Specimen bushes.

$\$ 400$

600

900

1000

Amelanchier alnifolia (Juneberry).

18 to 24 in., nursery row.

2 to $3 \mathrm{ft}$., nursery row

2 to $3 \mathrm{ft}$., transplanted

Specimen bushes.

125

$\$ 150$ to 300

Aralia Chinensis (Dimorphanthus Mandschuricus).

2 to $3 \mathrm{ft}$., nursery row.

3 to $4 \mathrm{ft}$., nursery row.

3 to $4 \mathrm{ft}$., transplanted

4 to $5 \mathrm{ft}$., transplanted

$\$ 050$

60

$\$ 400$

500

$80 \quad 700$

Specimen bushes. .

$\$ 1$ to 200

$\$ 0 \quad 60 \quad \$ 500$

$80 \quad 700$

$\begin{array}{llll}125 & 10 & 00\end{array}$

$\begin{array}{llll}1 & 50 & 12 & 50\end{array}$
Aralia pentaphylla.

2 to $3 \mathrm{ft}$., nursery row

2 to $3 \mathrm{ft}$., transplanted

3 to $4 \mathrm{ft}$., transplanted

Barberry, Thunberg's

Japanese Barberry.

12 to 18 in., nursery row

18 to 24 in., nursery row

18 to 24 in., transplanted

24 to 30 in., transplanted

30 to 36 in., transplanted

Specimen bushes.

Buffalo Berry (Shepherdia argentea)

18 to 24 in., nursery row

2 to $3 \mathrm{ft}$., nurserỳ row

2 to $3 \mathrm{ft}$., transplanted

3 to $4 \mathrm{ft}$., transplanted

Specimen shrubs.

18 to 24 in., nursery row

2 to $3 \mathrm{ft}$., nursery row

2 to $3 \mathrm{ft}$., transplanted

3 to $4 \mathrm{ft}$., transplanted

4 to $5 \mathrm{ft}$., transplanted

Specimen shrubs

Each

$80 \begin{array}{lll}60 & 500 \\ 80 & & 00\end{array}$

(Berberis Thunbergii).

$\$ 030 \quad \$ 250$

35300

40 . 350

$60 \quad 500$

80700

200

$\$ 0 \quad 35 \$ 300$

$50 \quad 400$

$\begin{array}{lll}60 & 5 & 00\end{array}$

$80 \quad 700$

$\$ 1$ to 200

Rhamnus catharticus).

$\$ 035 \$ 300$

$\begin{array}{lll}50 & 4 & 00\end{array}$

$\begin{array}{lll}60 & 5 & 00\end{array}$

$80 \quad 700$

$\begin{array}{lll}125 & 1000\end{array}$ 


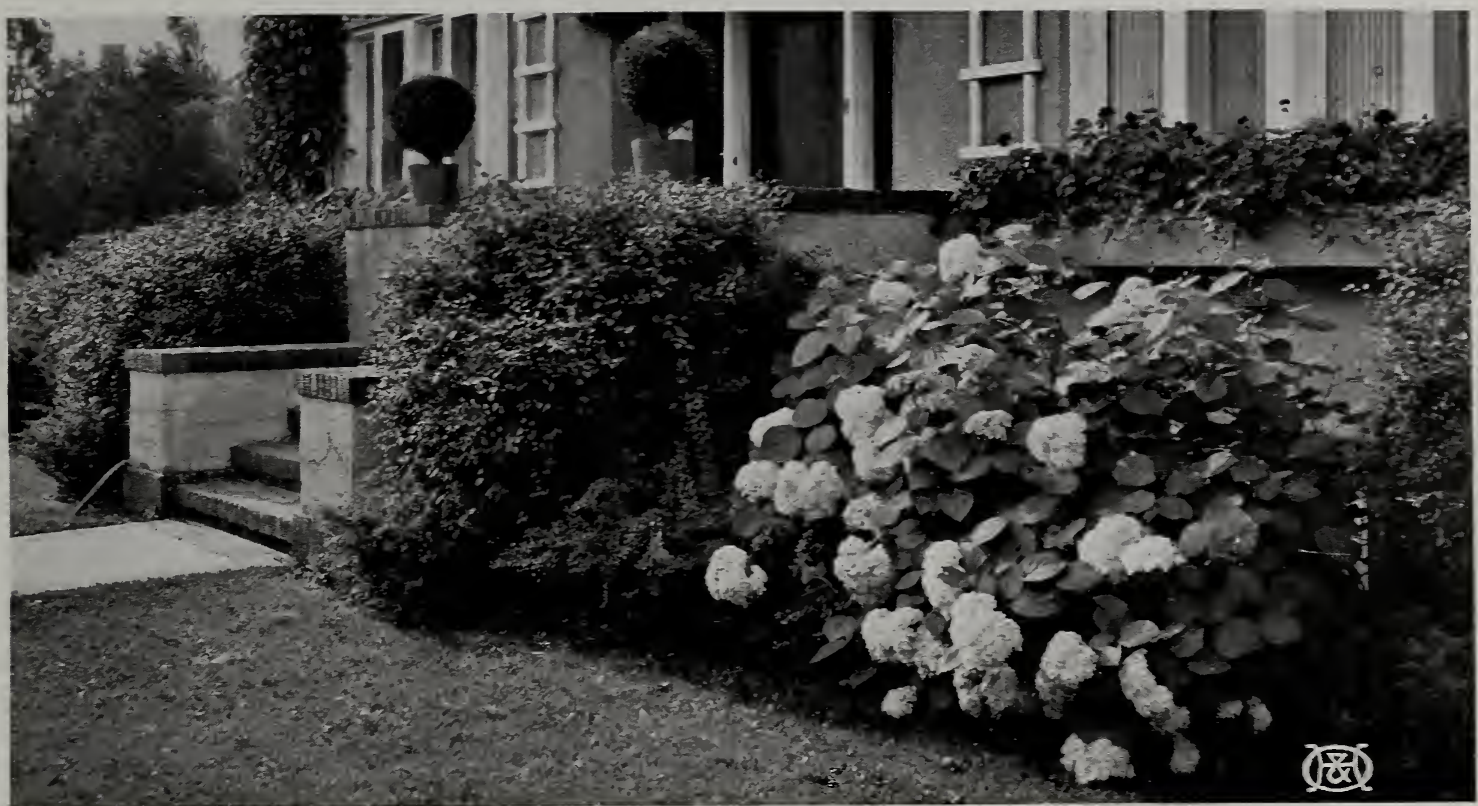

A north side planting-see how happy the Snowball Hydrangeas look

Buckthorn, Carolina, or Indian Cherry (Rhamnus Caroliniana).

2 to $3 \mathrm{ft}$, nursery row.

2 to $3 \mathrm{ft}$., transplanted

3 to $4 \mathrm{ft}$., transplanted.

4 to $5 \mathrm{ft}$., transplanted

Clethra alnifolia.

18 to $2 t$ in., nursery row

18 to 24 in., transplanted

2 to $3 \mathrm{ft}$., transplanted

Specimen shrubs

Cotoneaster acutifolia.

2 to $3 \mathrm{ft}$., transplanted

3 to $4 \mathrm{ft}$., transplanted

4 to $5 \mathrm{ft}$., transplanted

Specimen shrubs.

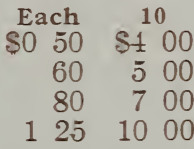

$\$ 0 \quad 35 \$ 300$

$50 \quad 400$

60500

$\$ 1$ to 200

$\begin{array}{lrrrr}\ldots . . . & \$ 0 & 60 & \$ 5 & 00 \\ \ldots . . . & & 80 & 7 & 00 \\ \ldots \ldots & 1 & 25 & 10 & 00 \\ \text { \$1 } 50 \text { to } & 2 & 00 & & \end{array}$

Cephalanthus occidentalis (Button Bush). Clusters of white flowers in ball-like form; bright glossy foliage. It is a hardy strong grower, and splendid for grouping.

2 to $3 \mathrm{ft}$., nursery row

2 to $3 \mathrm{ft}$., transplanted

3 to $4 \mathrm{ft}$., transplanted

$\$ 0 \quad 50 \quad \$ 400$

60500

$80 \quad 7 \quad 00$

Currant, Yellow (Ribes aureum).

18 to $2 t$ in., nursery row.

2 to $3 \mathrm{ft}$., nursery row

2 to $3 \mathrm{ft}$., transplanted

3 to $4 \mathrm{ft}$., transplanted

4 to $5 \mathrm{ft}$., transplanted

Specimen shrubs

.

$\begin{array}{lrrrr}\ldots \ldots . & \$ 0 & 35 & \$ 3 & 00 \\ \ldots \ldots & 50 & 4 & 00 \\ \ldots \ldots . & 60 & 5 & 00 \\ \ldots \ldots & 80 & 7 & 00 \\ \ldots \ldots & 1 & 25 & 10 & 00\end{array}$

Currant, Mountain (Ribes alpinum). Fragrant, yellow flowers; good foliage. An interesting, beautiful shrub, of dwarf, compact habit. Bears clusters of scarlet fruit.
18 to 24 in., nursery row
2 to $3 \mathrm{ft}$., nursery row.
2 to $3 \mathrm{ft}$., transplanted
Specimen shrubs
$\$ 0 \quad 50 \$ 100$
60500
80700
$\$ 1$ to 200

Deutzia gracilis. A neat, dense little bush, rarely over 2 feet high, that blooms in May, wreathing its drooping branches with pure white flowers. Equally valuable for shrubberies and forcing. Fine for growing in front of taller shrubs.
12 to 18 in., nursery row.
$\$ 0 \quad 50 \$ 100$

12 to 18 in., transplanted.

$60 \quad 500$
Deutzia, Pride of Rochester. 18 to 24 in., nursery row...

2 to $3 \mathrm{ft}$., nursery row

2 to $3 \mathrm{ft}$. , transplanted

3 to $4 \mathrm{ft}$., transplanted.

Specimen shrubs.

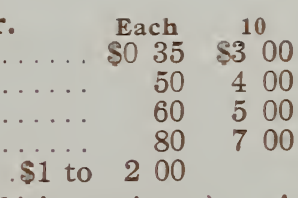

Dogwood, Silver (Cornus Sibirica variegata). A large, spreading shrub, 6 to 10 feet high, with clusters of white flowers in June, variegated foliage and coral-red bark. Nothing is more attractive in a shrub border; its white and light green leaves, so different from those of other shrubs, make it distinct.

18 to 24 in., nursery row.

2 to $3 \mathrm{ft}$., nursery row.

2 to $3 \mathrm{ft}$., transplanted.

$\$ 0 \quad 60 \$ 500$

3 to $4 \mathrm{ft}$., transplanted.

$\begin{array}{llll}1 & 00 & 9 & 00\end{array}$

1251000

Dogwood, Golden Bark (Cornus aurea).

2 to $3 \mathrm{ft}$., nursery row......... s0 50 \$ 100

2 to $3 \mathrm{ft}$., transplanted........... $60 \quad 500$

3 to $4 \mathrm{ft}$., transplanted......... $80 \quad 7,00$

4 to $5 \mathrm{ft}$., transplanted.......... 1251000

Specimen shrubs.......\$1 50 to 200

Dogwood, Panicled (Cornus paniculata).

18 to 24 in., nursery row........ s0 35

2 to $3 \mathrm{ft}$., nursery row.

2 to $3 \mathrm{ft}$., transplanted.

3 to $4 \mathrm{ft}$., transplanted

$\$ 300$

$50 \quad 400$

60500

Dogwood, Red-twigged (Cornus Sibirica alba).

18 to 21 in., nursery row........ \$0 35 \$3 00

2 to $3 \mathrm{ft}$., nursery row.

2 to $3 \mathrm{ft}$., transplanted

3 to $4 \mathrm{ft}$., transplanted

4 to $5 \mathrm{ft}$., transplanted.

Specimen shrubs.

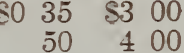

60500

80700

1251000

, Red Osier (Cornus stolonifera).

2 to $3 \mathrm{ft}$., nursery row......... \$0 50 \$4 00

2 to $3 \mathrm{ft}$., transplanted............. $60 \quad 500$

3 to $4 \mathrm{ft}$., transplanted......... $80 \quad 700$

4 to $5 \mathrm{ft}$., transplanted........... 1251000

Specimen shrubs......\$1 50 to 200

Elder, Cut-leaved (Sambucus nigra laciniata).

2 to $3 \mathrm{ft}$., nursery row.......... \$0 50 \$4 00

2 to $3 \mathrm{ft}$., transplanted

$60 \quad 500$

3 to $4 \mathrm{ft}$., transplanted

4 to $5 \mathrm{ft}$., transplanted

Specimen shrubs.....

$80 \quad 700$

$125 \quad 1000$

$\$ 150$ to 200 


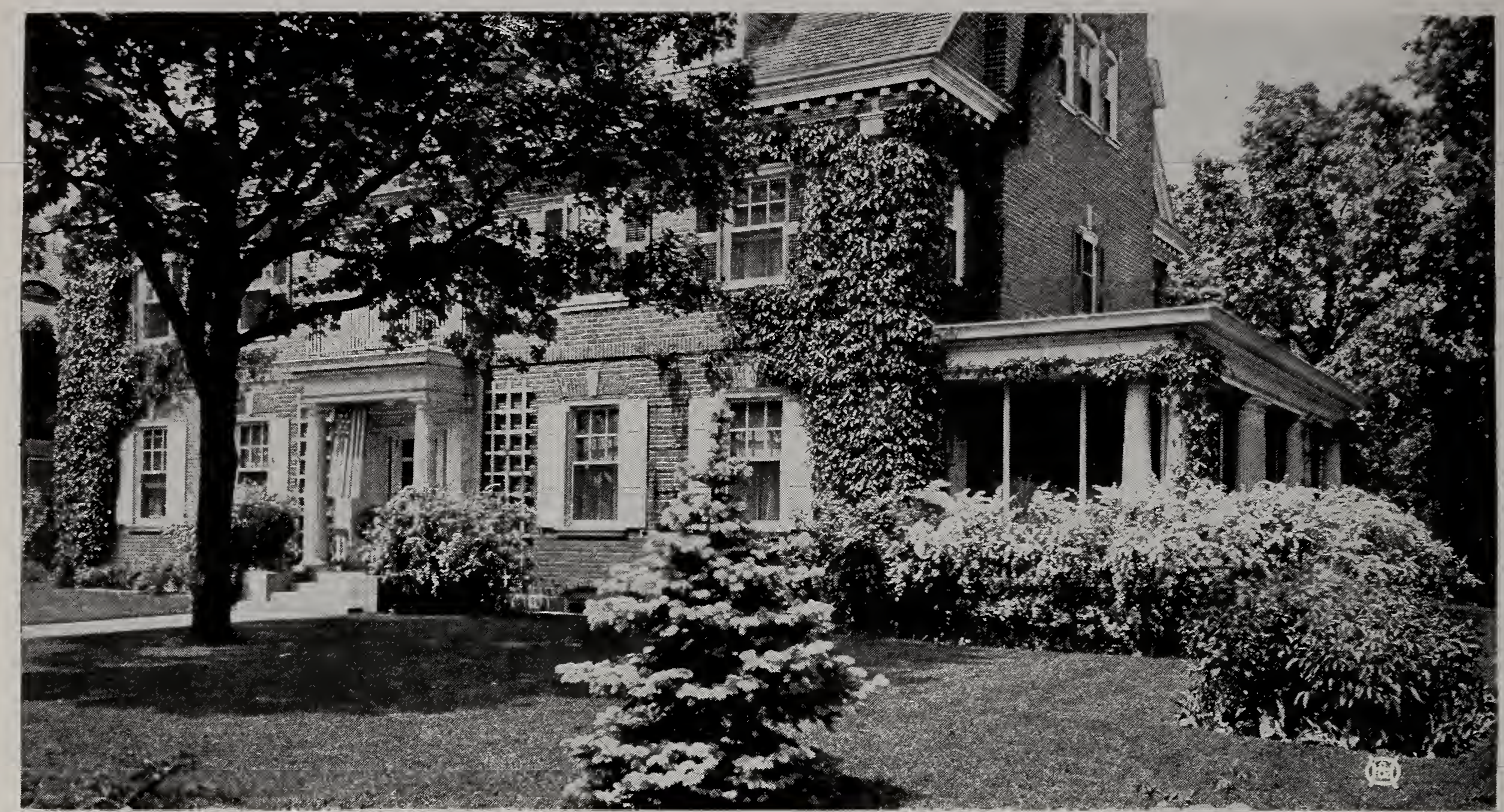

Among the multitude of shrubs available for foundation planting the Spireas hold first place

Elder, Golden (Sambucu
2 to $3 \mathrm{ft}$., nursery row
2 to $3 \mathrm{ft}$., transplanted

3 to $4 \mathrm{ft}$., transplanted

4 to $5 \mathrm{ft}$., transplanted

Specimen shrubs

$\$ 150$ to 250

Elder, Red-berried (Sambucus racemosus)

2 to $3 \mathrm{ft}$., nursery row

2 to $3 \mathrm{ft}$., transplanted

3 to $4 \mathrm{ft}$., transplanted

4 to $5 \mathrm{ft}$., transplanted

Specimen shrubs

$\$ 050$

$50-500$

807700

125

$\$ 150$ to 300

1000

Euonymus Americana (Burning Bush).

2 to $3 \mathrm{ft}$., nursery row.

2 to $3 \mathrm{ft}$., transplanted

3 to $4 \mathrm{ft}$., transplanted

4 to $5 \mathrm{ft}$.. transplanted.

$\$ 050$

$\$ 400$

500

700

125

1000

Euonymus, Corkbark (Euonymus elatus).

2 to $3 \mathrm{ft}$., transplanted

3 to $4 \mathrm{ft}$., transplanted

Specimen shrubs

$\$ 150 \$ 1300$

$250 \quad 2200$

Elaeagnus argentea (Russian Olive).

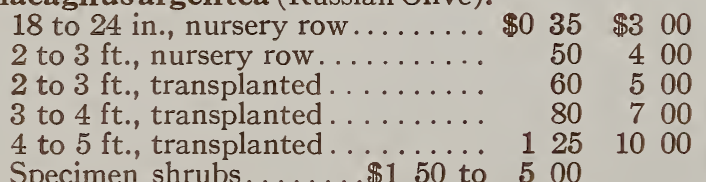

Forsythia, Fortune's (Forsythia Fortunei).

18 to 24 in., nursery row.......\$0 35

2 to $3 \mathrm{ft}$., nursery row

2 to $3 \mathrm{ft}$., transplanted

3 to $4 \mathrm{ft}$., transplanted.

4 to $5 \mathrm{ft}$., transplanted

Specimen bushes.

50

$\$ 300$

400

$60 \quad 500$

80700

1251000

Forsythia suspensa (Golden Bell).

18 to 24 in., nursery row.

2 to $3 \mathrm{ft}$., nursery row

2 to $3 \mathrm{ft}$., transplanted.

3 to $4 \mathrm{ft}$., transplanted

4 to $5 \mathrm{ft}$., transplanted

Specimen bushes.

$\$ 150$ to 300

1000

Forsythia viridissima.

2 to $3 \mathrm{ft}$., nursery row.

2 to $3 \mathrm{ft}$., transplanted

3 to $4 \mathrm{ft}$., transplanted.
$\$ 0 \quad 35 \$ 300$

$50 \quad 400$

60500

80700

1251000

$\$ 150$ to 300 $\begin{array}{lll}50 & \$ 4 & 00 \\ 60 & 5 & 00\end{array}$

80700

Fringe, Purple, or Mist Tree (Rhus Cotinus)

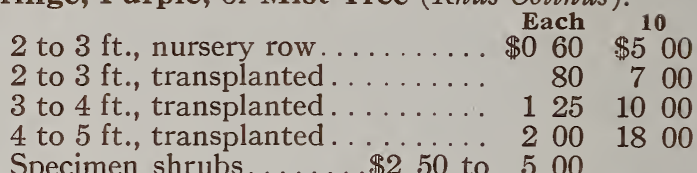

Specimen shrubs

$\$ 250$ to 500

Fringe, White (Chionanthus Virginica)

2 to $3 \mathrm{ft} .$, nursery row.........\$0 $60 \quad \$ 500$

2 to $3 \mathrm{ft}$., transplanted

3 to $4 \mathrm{ft}$., transplanted

Specimen shrubs.

$\begin{array}{lll}80 & 7 & 00\end{array}$

1251000 Aawthorn, or Native Thorn Apple.

2 to $3 \mathrm{ft}$., transplanted.......... \$0 50 \$4 00

3 to $4 \mathrm{ft}$., transplanted. . . . . . . . $80 \quad 700$

4 to $5 \mathrm{ft}$., transplanted......... $125 \quad 1000$

Honeysuckle, Bella (Lonicera bella allbida).

2 to $3 \mathrm{ft}$., nursery row......... \$0 50 \$4 00

2 to $3 \mathrm{ft}$. , transplanted......... $60 \quad 500$

3 to $4 \mathrm{ft}$., transplanted......... $80 \quad 700$

Honeysuckle, Fragrant (Lonicera fragrantissima). 18 to 24 in., nursery row........\$0 $35 \$ 300$ 2 to $3 \mathrm{ft}$., nursery row ......... $50 \quad 400$ 2 to $3 \mathrm{ft}$., transplanted......... $60 \quad 500$ 3 to $4 \mathrm{ft}$., transplanted......... $80 \quad 700$

Honeysuckle, Ledebour (Lonicera Ledebouri).
2 to $3 \mathrm{ft}$., nursery row .
$\$ 050 \$ 400$

2 to $3 \mathrm{ft}$., transplanted

$60 \quad 500$

3 to $4 \mathrm{ft}$., transplanted

$80 \quad 700$

Honeysuckle, Red Tartarian (Lonicera Tatarica). 18 to 24 in., nursery row........ \$0 35 $\$ 300$ 2 to $3 \mathrm{ft}$., nursery row......... $50 \quad 400$ 2 to $3 \mathrm{ft}$., transplanted . . . . . . ..... $60 \quad 500$ 3 to $4 \mathrm{ft}$., transplanted.......... $80 \quad 700$ 4 to $5 \mathrm{ft}$., transplanted . . . . . . . . 1251000 Specimen shrubs......\$1 50 to 500

Honeysuckle, Pink Tartarian (Lonicera rosea).

18 to 24 in., nursery row........ \$0 35 $\$ 300$

2 to $3 \mathrm{ft}$., nursery row........ $50 \quad 400$

2 to $3 \mathrm{ft}$., transplanted . . . . . . ..... $60 \quad 500$

3 to $4 \mathrm{ft}$., transplanted ......... $80 \quad 700$

4 to $5 \mathrm{ft}$., transplanted .......... 1251000

Specimen shrubs......\$150 to 500

Honeysuckle, White Tartarian (Lonicera alba).

18 to 24 in., nursery row........ \$0 $35 \$ 300$

2 to $3 \mathrm{ft}$., nursery row......... $50 \quad 400$

2 to $3 \mathrm{ft}$., transplanted......... $60 \quad 500$

3 to $4 \mathrm{ft}$., transplanted ......... $80 \quad 700$

4 to $5 \mathrm{ft}$., transplanted.......... 1251000

Specimen shrubs......\$1 50 to 400 


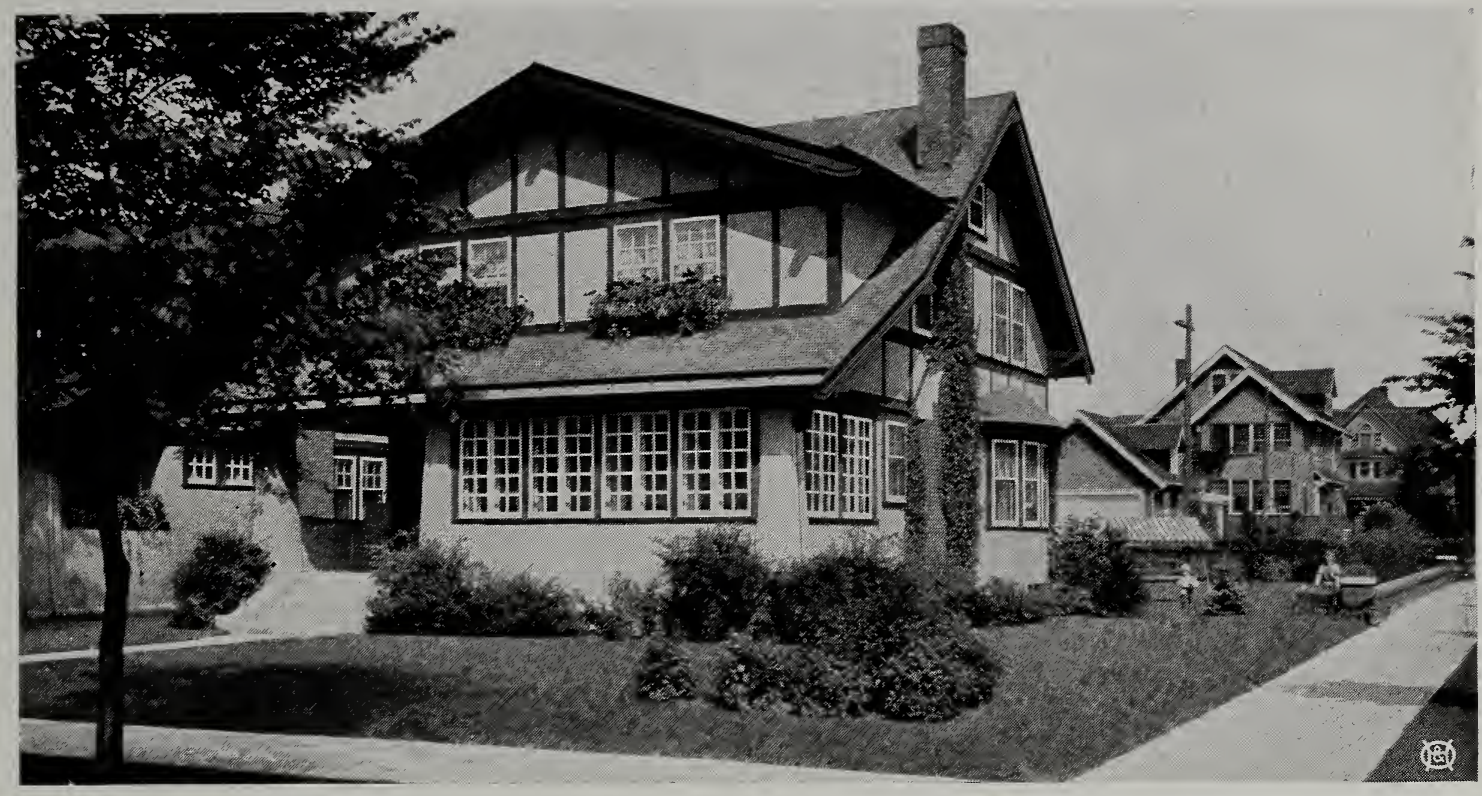

Showing results of the first year of planting

Honeysuckle, Morrow's (Lonicera Morrowi).

18 to 24 in., nursery row

2 to $3 \mathrm{ft}$., nursery row.

2 to $3 \mathrm{ft}$., transplanted

3 to $4 \mathrm{ft}$., transplanted

Specimen shrubs.

(Aesculus parviflora).

12 to 18 in., transplanted

18 to 24 in., transplanted

$\$ 100 \quad \$ 800$

$150 \quad 1250$

Hydrangea, Large-flowered (Hydrangea paniculata grandiflora).

18 to 24 in., nursery row.

2 to $3 \mathrm{ft}$., nursery row.

2 to $3 \mathrm{ft}$., transplanted

3 to $4 \mathrm{ft}$., transplanted

Specimen shrubs.

$\$ 035 \$ 300$

$50 \quad 400$

$60 \quad 500$

$80 \quad 700$

$\$ 1$ to 200

Hydrangea, Tree. Same as the former, but grown

in tree form, and bears great trusses of flowers.

3 to $4 \mathrm{ft}$., nursery row.......... $\$ 100 \quad \$ 900$

3 to $4 \mathrm{ft}$., transplanted.......... $125 \quad 1000$

4 to $5 \mathrm{ft}$., transplanted........... $150 \quad 1300$

Specimen shrubs......\$2 00 to 350

Hydrangea arborescens grandiflora (Everblooming Snowball Hydrangea).

18 to 24 in., nursery row........ $\$ 0 \quad 50 \quad \$ 400$

2 to $3 \mathrm{ft}$., transplanted.......... $\quad 80 \quad 700$

3 to $4 \mathrm{ft}$., transplanted......... $100 \quad 900$

Specimen shrubs.........\$2 to 300

Lilac, Common Purple (Syringa vulgaris).

18 to 24 in., nursery row......... $\$ 035$

2 to $3 \mathrm{ft}$., nursery row .......... 50

2 to $3 \mathrm{ft}$., transplanted

3 to $4 \mathrm{ft}$., transplanted

4 to $5 \mathrm{ft}$., transplanted

Specimen shrubs.

$50-400$

$60-500$

$80 \quad 700$

$\begin{array}{llll}125 & 10 & 00\end{array}$

18 to 24 in., nursery row........ $\$ 035$

2 to $3 \mathrm{ft}$., nursery row

2 to $3 \mathrm{ft}$., transplanted

3 to $4 \mathrm{ft}$., transplanted

4 to $5 \mathrm{ft}$., transplanted

Specimen shrubs.

50

60

$80 \quad 700$

$125 \quad 1000$

Lilac, Persian (Syringa Persica).

18 to 24 in., nursery row.

2 to $3 \mathrm{ft}$., nursery row.

2 to $3 \mathrm{ft}$., transplanted

3 to $4 \mathrm{ft}$., transplanted

4 to $5 \mathrm{ft}$., transplanted

Specimen shrubs.
$\$ 050 \quad \$ 400$

$\begin{array}{lll}60 & 5 & 00\end{array}$

$80 \quad 700$

$\begin{array}{llll}1 & 00 & 9 & 00\end{array}$

$\begin{array}{llll}1 & 50 & 12 & 00\end{array}$
$\$ 250$ to 500

Lilac, White Persian (Syringa Persica alba).

2 to $3 \mathrm{ft}$., nursery row

2 to $3 \mathrm{ft}$., transplanted

3 to $4 \mathrm{ft}$., transplanted.

Specimen shrubs

Lilac, Giant Tree (Syringa Japonica).

2 to $3 \mathrm{ft}$., nursery row

2 to $3 \mathrm{ft}$., transplanted

3 to $4 \mathrm{ft}$., transplanted

4 to $5 \mathrm{ft}$., transplanted

Specimen shrubs

Lilac, Hungarian (Syringa Josikaea).

2 to $3 \mathrm{ft}$., nursery row

2 to $3 \mathrm{ft}$., transplanted

3 to $4 \mathrm{ft}$., transplanted

Specimen shrubs

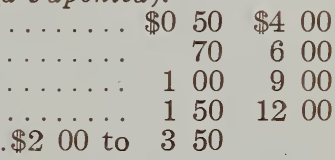

Each
$\$ 060$$\quad \$ 5^{10} 00$

$\begin{array}{lll}80 & 7 & 00\end{array}$

$\begin{array}{llll}100 & 9 & 00\end{array}$

Lilac, Himalayan (Syringa villosa).

2 to $3 \mathrm{ft}$., nursery row

2 to $3 \mathrm{ft}$., transplanted

3 to $4 \mathrm{ft}$., transplanted

Specimen shrubs.

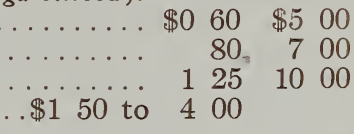

Named French Varieties of Lilacs. The named sorts are much superior to the old type of Common Purple and White and bloom much earlier.

2 to $3 \mathrm{ft}$., transplanted . . . . . . . . . $\$ 0 \quad 80 \quad \$ 700$

3 to $4 \mathrm{ft}$., transplanted

4 to $5 \mathrm{ft}$., transplanted

Specimen shrubs.

4 to $5 \mathrm{ft}$., tree form

Specimen trees.

$\$ 250$ to 200

$125 \quad 1000$

$200 \quad 1800$

$\$ 250$ to 1000

$\$ 3$ to 750

2200

Alphonse Lavallee. Fine blue, shaded violet.

Belle de Nancy. Satiny rose, white center.

Charles X. Reddish purple; large.

Dr. Masters. Clear lilac; superb.

Ludwig Spaeth. Dark purplish red; superb.

Marie Legraye. One of the finest white Lilacs.

Michael Buchner. Dwarf; pale lilac.

Madame Lemoine. Fine, double, white Lilac.

President Carnot. Pale blue.

President Grevy. A beautiful blue.

President Viger. Bluish lilac; extra.

Rubra de Marly. Purplish red; fine.

Locust, Pink (Robinia hispida).

2 to $3 \mathrm{ft}$., transplanted

3 to $4 \mathrm{ft}$., transplanted

Specimen shrubs.

$\$ 0 \quad 80 \quad \$ 7 \quad 00$

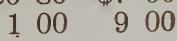


Matrimony Vine (Lycium Chinense). Each 2 to $3 \mathrm{ft}$., nursery row.

2 to $3 \mathrm{ft}$., transplanted

3 to $4 \mathrm{ft}$., transplanted

Specimen shrubs

$\$ 050$

60

80

Plum, Double-flowering (Prunus triloba)

2 to $3 \mathrm{ft}$., nursery row.

2 to $3 \mathrm{ft}$., transplanted

3 to $4 \mathrm{ft}$., transplanted

Specimen shrubs.

$\$ 0 \quad 60 \quad \$ 500$

80700

1251000

Potentilla fruticosa.

12 to 18 in., nursery row........ \$0 50 \$4 00

18 to 24 in., transplanted

Privet, Regel's (Ligustrum Regelianum).

2 to $3 \mathrm{ft}$., nursery row.

2 to $3 \mathrm{ft}$., transplanted

3 to $4 \mathrm{ft}$., transplanted

Privet, Ibota (Ligustrum Ibota).

2 to $3 \mathrm{ft}$., nursery row

2 to $3 \mathrm{ft}$., transplanted

3 to $4 \mathrm{ft}$., transplanted

Specimen shrubs

\begin{tabular}{l}
$70 \quad 600$ \\
\hline
\end{tabular}

$\$ 0 \quad 50 \quad \$ 400$

$\begin{array}{lll}60 & 5 & 00\end{array}$

$80 \quad 700$

Pyrus arbutifolia (Choke Cherry).

2 to $3 \mathrm{ft}$., nursery row

2 to $3 \mathrm{ft}$., transplanted

3 to $4 \mathrm{ft}$., transplanted

Specimen shrubs

$\$ 0 \quad 50 \quad \$ 400$

$\begin{array}{lll}60 & 5 & 00\end{array}$

$80 \quad 7 \quad 00$

Quince, Japan (Cydonia Japonica)

18 to 24 in., nursery row

2 to $3 \mathrm{ft}$., transplanted

Specimen shrubs.

$\$ 0 \quad 50 \$ 400$

$60 \quad 500$

$80 \quad 700$

18 to 24 in., nursery row

2 to $3 \mathrm{ft}$., nursery row

2 to $3 \mathrm{ft}$. , transplanted

3 to $4 \mathrm{ft}$., transplanted

4 to $5 \mathrm{ft}$., transplanted.

Specimen shrubs

Snowball, Carles'(Viburnum Carlesii)

2 to $3 \mathrm{ft}$., transplanted

3 to $4 \mathrm{ft}$., transplanted

$\$ 1$ to 200

$\$ 0 \quad 35 \$ 300$

$60 \quad 500$

(Viburnum Opulus sterile).

18 to 24 in., nursery row....... $\$ 035 \$ \$ 300$

2 to $3 \mathrm{ft}$., nursery row

2 to $3 \mathrm{ft}$., transplanted

3 to $4 \mathrm{ft}$., transplanted

4 to $5 \mathrm{ft}$., transplanted

Specimen shrubs.

$\$ 035 \$ 300$

$50 \quad 400$

$60 \quad 500$

80700

$125 \quad 1000$

Snowball, Tree or Standard.

4 to $5 \mathrm{ft}$., transplanted (Viburnum dentatum).

2 to $3 \mathrm{ft}$., nursery row. ......... \$0 $50 \$ 400$

2 to $3 \mathrm{ft}$., transplanted

3 to $4 \mathrm{ft}$., transplanted.

Specimen shulubs.

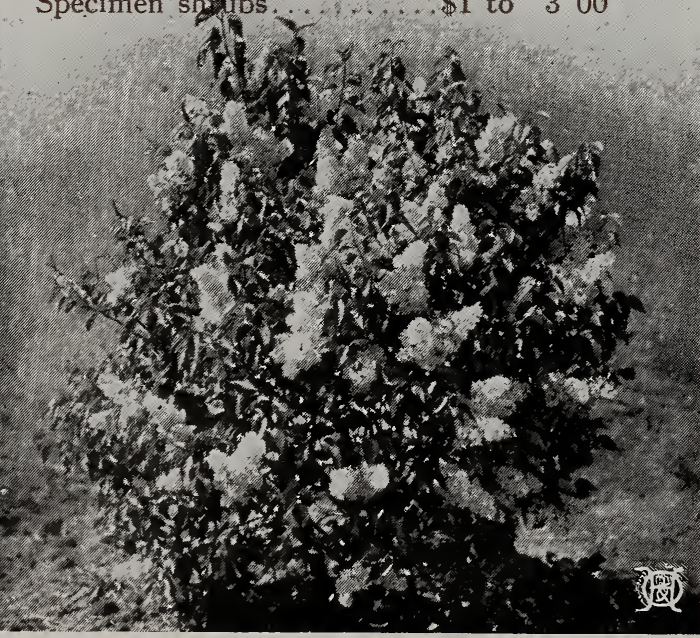

$60 \div 500$

$80-7.00$

\section{(1)}

Specimen French Lilac, Marie Legraye
Snowball, Wayfaring Tree (Viburnum Lantana).

2 to $3 \mathrm{ft}$., nursery row

Each 10

2 to $3 \mathrm{ft}$., transplanted

$60 \quad 500$

3 to $4 \mathrm{ft}$., transplanted

80700

Specimen shrubs.

$\$ 150$ to 500

Snowball, Lentage Sheepberry(ViburnumLentago). 2 to $3 \mathrm{ft}$., nursery row......... \$0 $60 \$ 500$

2 to $3 \mathrm{ft}$., transplanted.

3 to $4 \mathrm{ft}$., transplanted

80700 ulus).

18 to 24 in., nursery row....... \$0 $35 \$ 300$

2 to $3 \mathrm{ft}$., nursery row......... $50 \quad 400$

2 to $3 \mathrm{ft}$., transplanted........ $60 \quad 500$

3 to $4 \mathrm{ft}$, transplanted . . . . . . . $\quad 80 \quad 700$

4 to $5 \mathrm{ft}$., transplanted . . . . . . . . $125 \quad 1000$

Specimen shrubs......\$1 50 to 500

Snowball, High-bush Cranberry (Viburnum Opulus), American Type. Quite different from the regular type; leaves glossy green with red stems, and are free from insects.

18 to 24 in., nursery row . . . . . . . \$0 50 \$4 00

2 to $3 \mathrm{ft}$., nursery row.

2 to $3 \mathrm{ft}$. , transplanted

$\begin{array}{rrr}50 & \$ 4 & 00 \\ 60 & 5 & 00\end{array}$

3 to $4 \mathrm{ft}$., transplanted.

4 to $5 \mathrm{ft}$., transplanted.

80700

Specimen shrubs.......

$100 \quad 900$

$\begin{array}{llll}1 & 50 & 12 & 00\end{array}$

Snowball, Dwarf Cranberry (Viburnum Opulus nanum).

$\begin{array}{rlrrrr}10 & \text { to } 12 \text { in., transplanted ......... } & \$ 0 & 50 & \$ 4 & 00 \\ 12 \text { to } 15 \text { in., transplanted ... . . . . } & 75 & 6 & 00\end{array}$

18 to 24 in., transplanted

1009900

Snowball, Japanese (Viburnum tomentosum plicatum).

2 to $3 \mathrm{ft}$., nursery row

2 to $3 \mathrm{ft}$., transplanted

$\$ 0 \quad 60 \$ 500$

3 to $4 \mathrm{ft}$., transplanted

600

Snowberry, Red, or Indian Currant (Symphoricarpos vulgaris).

18 to 24 in., nursery row........ $\$ 030 \$ 300$

2 to $3 \mathrm{ft}$., nursery row......... $50 \quad 400$

2 to $3 \mathrm{ft}$., transplanted

3 to $4 \mathrm{ft}$., transplanted.

$\begin{array}{lll}60 & 5 & 00\end{array}$

Specimen shrubs.......\$1 to 350

Snowberry, White (Symphoricarpos racemosus).

18 to 24 in., nursery row $\ldots \ldots \ldots . . . \$ 035 \$ \$ 300$

2 to $3 \mathrm{ft}$., nursery row. ......... 50 . 400

2 to $3 \mathrm{ft}$., transplanted........ $60 \quad 500$

3 to $4 \mathrm{ft}$., transplanted $\quad 80 \quad 700$

Specimen shrilds. 1 to 350 :

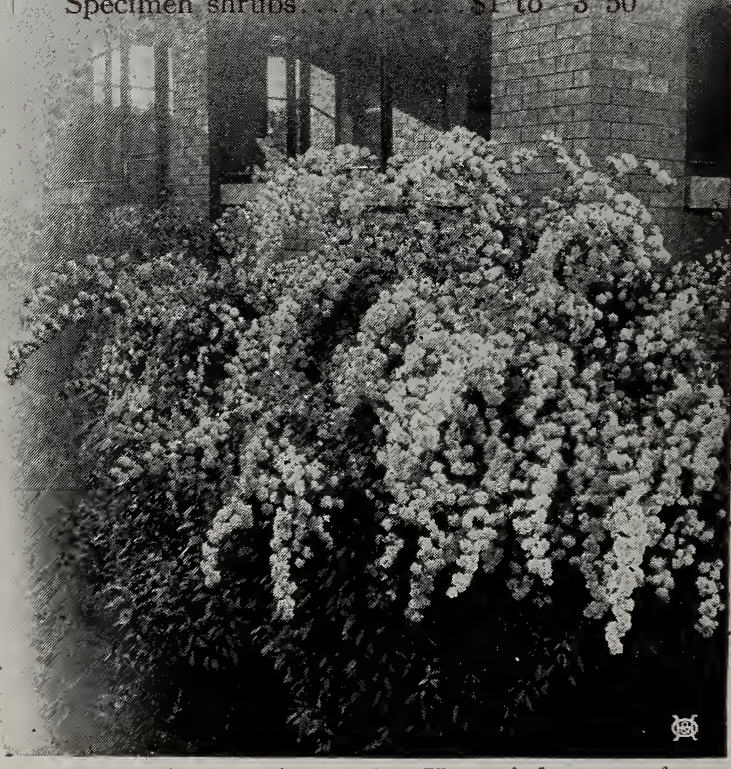

A specimen Spiraea Van Houttei the year after planting-results without waiting 
Snowberry, Variega ted (Symphoricarpos variegatus).

18 to 24 in., transplanted ........ $\$$ \$0 $60 \quad \$ 500$ 2 to $3 \mathrm{ft}$., transplanted.

Spiraea, Anthony Waterer. Dwarf.

12 to 18 in., nursery row........ \$0 $35 \$ \$ 300$

18 to 24 in., nursery row....... $50 \quad 400$

18 to 24 in., transplanted....... $60 \quad 500$

Specimen shrubs........\$1 to 200

Spiraea arguta.

2 to $3 \mathrm{ft}$., nursery row

2 to $3 \mathrm{ft}$., transplanted

3 to $4 \mathrm{ft}$., transplanted

Specimen shrubs.

Spiraea aurea (Golden Spirea).

2 to $3 \mathrm{ft}$., nursery row

2 to $3 \mathrm{ft}$., transplanted.

3 to $4 \mathrm{ft}$., transplanted

4 to $5 \mathrm{ft}$., transplanted.

Specimen shrubs......\$1 50 to 350

\section{Spiraea Billiardii.}

2 to $3 \mathrm{ft}$., nursery row

2 to $3 \mathrm{ft}$., transplanted

3 to $4 \mathrm{ft}$., transplanted

4 to $5 \mathrm{ft}$., transplanted.

Specimen shrubs.

$\$ 1$ to

Spiraea Bumalda. Dwarf

12 to 18 in., nursery row.

18 to 24 in., nursery row

18 to 24 in., transplanted

Specimen shrubs.

Spiraea callosa alba. Dwarf.

$\$ 150$ to 250

$\$ 1$ to 200 f.

10 to 12 in., nursery row

12 to 18 in., transplanted.

18 to 24 in., transplanted

Specimen shrubs.

Spiraea callosa rubra.

12 to 18 in., nursery row

12 to 18 in., transplanted

18 to 24 in., transplanted

2 to $3 \mathrm{ft}$., transplanted.

Spiraea Douglasii.

2 to $3 \mathrm{ft}$., nursery row

2 to $3 \mathrm{ft}$., transplanted

3 to $4 \mathrm{ft}$., transplanted

Spiraea opulifolia.

2 to $3 \mathrm{ft}$., nursery row

2 to $3 \mathrm{ft}$., transplanted

3 to $4 \mathrm{ft}$., transplanted

4 to $5 \mathrm{ft}$., transplanted

Specimen shrubs.

Spiraea prunifolia.

2 to $3 \mathrm{ft}$., transplanted.

3 to $4 \mathrm{ft}$., transplanted

Spiraea Reevesii.

18 to 24 in., nursery row.

2 to $3 \mathrm{ft}$., nursery row

2 to $3 \mathrm{ft}$., transplanted

3 to $4 \mathrm{ft}$., transplanted

$\begin{array}{lrrr}\ldots \ldots & \$ 0 & 35 & \$ 300 \\ \ldots \ldots & 50 & 400 \\ \ldots \ldots & 60 & 500 \\ \$ 1 \text { to } & 2 & 00 & \end{array}$

$\$ 0 \quad 35 \quad \$ 300$

$50 \quad 400$

$60 \quad 500$

$80 \quad 700$

$\$ 0 \quad 50 \quad \$ \pm 00$

$60 \quad 500$

$80 \quad 700$

$\$ 0 \quad 50 \quad \$ 400$

60500

$80 \quad 700$

$\begin{array}{llll}1 & 25 & 10 & 00\end{array}$

$\$ 150$ to 250

$\$ 070 \quad \$ 6 \quad 00$

$100 \quad 900$

$\begin{array}{llll}\$ 0 & 35 & \$ 300\end{array}$

$50 \quad 400$

$60 \quad 500$

80700

Spiraea Reevesii flore pleno.

18 to 24 in., nursery row .

2 to $3 \mathrm{ft}$., nursery row.

2 to $3 \mathrm{ft}$., transplanted

3 to $4 \mathrm{ft}$., transplanted

Spiraea sorbifolia.

18 to 24 in., nursery row.

2 to $3 \mathrm{ft}$., nursery row.

2 to $3 \mathrm{ft}$., transplanted.

3 to $4 \mathrm{ft}$., transplanted.

Specimen shrubs.

Spiraea Thunbergii.

18 to 24 in., nursery row

18 to 24 in., transplanted

2 to $3 \mathrm{ft} .$, transplanted.
Spiraea Van Houttei (Bridal Wreath).

18 to 24 in., nursery row.

2 to $3 \mathrm{ft}$., nursery row

$\$ 0 \quad 50 \$ 400$
$80 \quad 700$

500

700

$\$ 0 \quad 50 \quad \$ 400$

$60 \quad 500$

$80 \quad 700$

$125 \quad 1000$

$\$ 0 \quad 50 \quad \$ 400$

$60-500$

$80 \quad 700$

$\begin{array}{llll}1 & 25 & 10 & 00\end{array}$

$\$ 0 \quad 35 \$ 300$

$50 \quad 400$

60500

2 to $3 \mathrm{ft}$., transplanted

3 to $4 \mathrm{ft}$., transplanted

4 to $5 \mathrm{ft}$., transplanted

Specimen shrubs.

Sumac Cut-leaved (R..\$1 50 to 500

(Rhus glabra laciniata)

12 to 18 in., nursery row

18 to 24 in., nursery row.

$\$ 050 \$ 400$

18 to 24 in., transplanted

2 to $3 \mathrm{ft}$., transplanted

Specimen shrubs.

$70 \quad 600$

$100 \quad 900$

$125 \quad 1000$

Sumac, Fragrant (Rhus aromatica).

2 to $3 \mathrm{ft}$., nursery row.

2 to $3 \mathrm{ft}$., transplanted.

$\$ 0 \quad 70 \quad \$ 600$

Syringa, Avalanche (Philadelphus hybrida).

2 to $3 \mathrm{ft}$., transplanted.

3 to $4 \mathrm{ft}$., transplanted

$\$ 080 \quad \$ 700$

$\begin{array}{llll}100 & 900\end{array}$

Syringa, Golden Dwarf (Philadelphus aureus).

10 to 12 in., nursery row.......\$0 $50 \$ 400$

12 to 18 in., nursery row.

12 to 18 in., transplanted

60500

18 to 24 in., transplanted

80700

Syringa grandiflora (Philadelphus grandiflorus)

2 to $3 \mathrm{ft}$., nursery row......... \$0 50 \$4 00

2 to $3 \mathrm{ft}$., transplanted .......... $60 \quad 500$

3 to $4 \mathrm{ft}$., transplanted.......... $80 \quad 700$

4 to $5 \mathrm{ft}$., transplanted

Specimen shrubs.

125

$\$ 150$ to 300

Syringa Lemoinei (Philadelphus Lemoinei).

18 to 24 in., nursery row........ \$0 $35 \$ 300$

2 to $3 \mathrm{ft}$., nursery row....... $50 \quad 400$

2 to $3 \mathrm{ft}$., transplanted

3 to $4 \mathrm{ft}$. , transplanted.......... $80 \quad 700$

Specimen shrubs.........\$1 to 200

Syringa, Mock Orange (Philadelphus coronarius).

2 to $3 \mathrm{ft}$., nursery row......... \$0 50 \$4 00

2 to $3 \mathrm{ft}$., transplanted .......... $60 \quad 500$

3 to 4 ft., transplanted......... $80 \quad 700$

4 to $5 \mathrm{ft}$., transplanted ......... 1251000

Specimen shrubs.....\$1 50 to 500

Syringa, Mont Blanc (Philadelphus Mont Blanc). 18 to 24 in., nursery row........ \$0 50 \$4 00

2 to $3 \mathrm{ft}$, nursery row......... $70 \quad 600$

2 to $3 \mathrm{ft}$. , transplanted......... $80 \quad 700$

Tamarix Odessana.

2 to $3 \mathrm{ft}$., nursery row......... \$0 $60 \quad \$ 5.00$

2 to $3 \mathrm{ft}$., transplanted......... $80 \quad 700$

3 to $4 \mathrm{ft}$., transplanted........ 1251000

Specimen shrubs......\$1 50 to 250

Tamarix hispida aestivalis.

2 to $3 \mathrm{ft}$., nursery row $\quad \$ 080 \quad \$ 700$

2 to $3 \mathrm{ft}$., transplanted........... $100 \quad 900$

3 to $4 \mathrm{ft}$., transplanted......... 1251000

Specimen shrubs......\$1 50 to 3.00

Weigela Desboisii (Diervilla hybrida).

18 to 24 in., nursery row....... \$0 50 \$ $\$ 40$

2 to $3 \mathrm{ft}$., nursery row .

2 to $3 \mathrm{ft}$., transplanted

$60 \quad 500$

3 to $4 \mathrm{ft}$., transplanted

$70 \quad 600$

Specimen shrubs.

$100 \quad 900$

Rathe (Dierv

18 to 24 in., nursery row........ \$0 50" $\$ t 00$

2 to $3 \mathrm{ft}$., transplanted.

600

3 to $4 \mathrm{ft}$., transplanted

70

100

Specimen shrubs.

$\$ 125$ to 200

900

Weigela rosea (Diervilla rosea).

80700
18 to 24 in., nursery row.

2 to $3 \mathrm{ft}$., nursery row.

\$0 50

2 to $3 \mathrm{ft}$., transplanted

3 to $4 \mathrm{ft}$., transplanted.

Specimen shrubs.

60500

Weigela rosea nana variegata.

18 to 24 in., nursery row........ \$0 50 \$t 00

2 to $3 \mathrm{ft}$., nursery row......... $60 \quad 500$

2 to $3 \mathrm{ft}$., transplanted ................ $70 \quad 600$

3 to $4 \mathrm{ft}$., transplanted........ $100 \quad 900$

Specimen shrubs.......\$1 25 to 250

$\$+00$

500

600

900

$0 \quad 35 \$ 300$

$50 \quad 400$ 


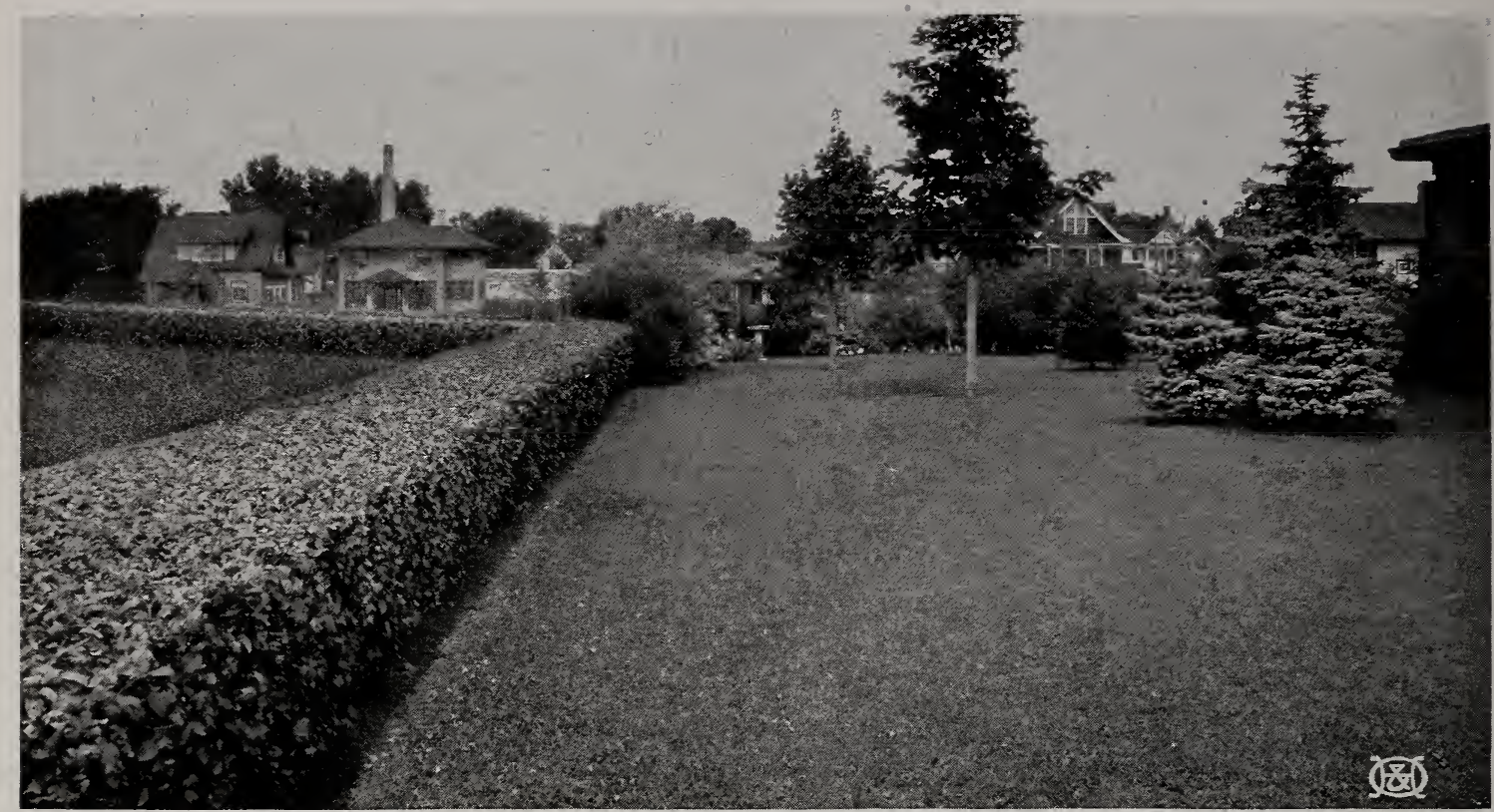

The Buckthorn makes one of the finest hedges for this section. It grows dense and forms the frame around the picture

\section{DECIDUOUS HEDGES}

$\mathrm{T}$ HERE is nothing quite so effective for the boundaries of a lawn or property division as a hedge. It does not decay, nor does it require paint, but grows more beautiful and effective each year. The first cost of installing a hedge is its only cost, so that, from an economical standpoint, it is less expensive than a fence.

When a hedge is desired for screening, high-growing varieties should be used that do not require trimming; but when it is to act as a border or division, use shrubs of low, dense-growing habit.

We recommend Buckthorn and Cotoneaster as being the best for the Northwest, with compact, dense growth and dark green foliage. Where a formal effect is wanted, these can be trimmed in any manner desired-rounded or flat on top, with square sides. They are very hardy, withstanding our severe winters.

When a low hedge is wanted, we recommend Thunberg's Barberry - this is one of the most attractive and ornamental hedges there is. It is much admired for its beautiful foliage, compact growth, and red berries in the fall.

Barberry, Thunberg's (Berberis Thunbergii).

12 to 18 in., nursery row

18 to $2 \times$ in., nưksery fow.

8 tb 24 inat transplanted

24 to 30 ind trantisplanted.

30 to 30 in trandanted

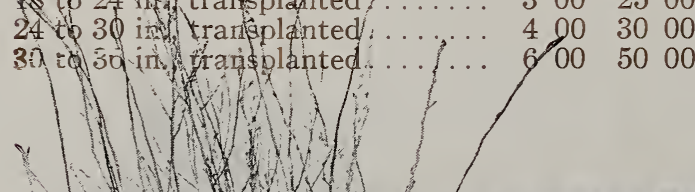

\section{Buckthorn (Rhamnus catharticus)}

18 to 24 in., nursery row...

18 to 24 in., transplanted.

2 to $3 \mathrm{ft}$., transplanted. .

3 to $4 \mathrm{ft}$., transplanted.

4 to $5 \mathrm{ft}$., transplanted.

5 to $6 \mathrm{ft}$., trans., heavy,

Per 10 Per 100

$\$ 200 \$ 1500$

$\begin{array}{llll}2 & 50 & 20 & 00\end{array}$

$300 \quad 2500$

$\begin{array}{llll}4 & 00 & 30 & 00\end{array}$

6005000

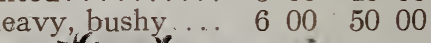

$\$ 200 \$ 1500$

$\begin{array}{llll}2 & 50 & 17 & 00\end{array}$

$\begin{array}{llll}3 & 00 & 2500\end{array}$

$\begin{array}{llll}3 & 50 & 30 & 00\end{array}$

$\begin{array}{llll}5 & 00 & 40 & 00\end{array}$

$\begin{array}{lllll}6 & 00 & 50 & 00\end{array}$

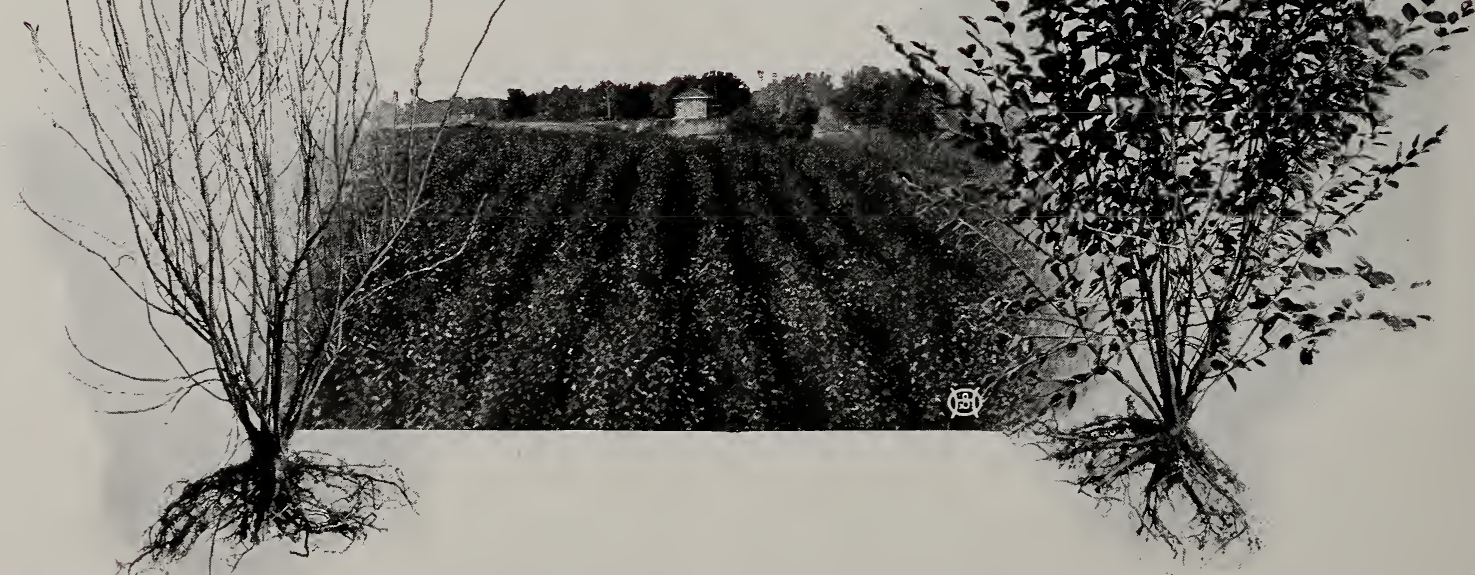

Illustrating Coloneaster plants singly and growing in our Nurseries. This is the most satisfactory hedge plant grown for this section 


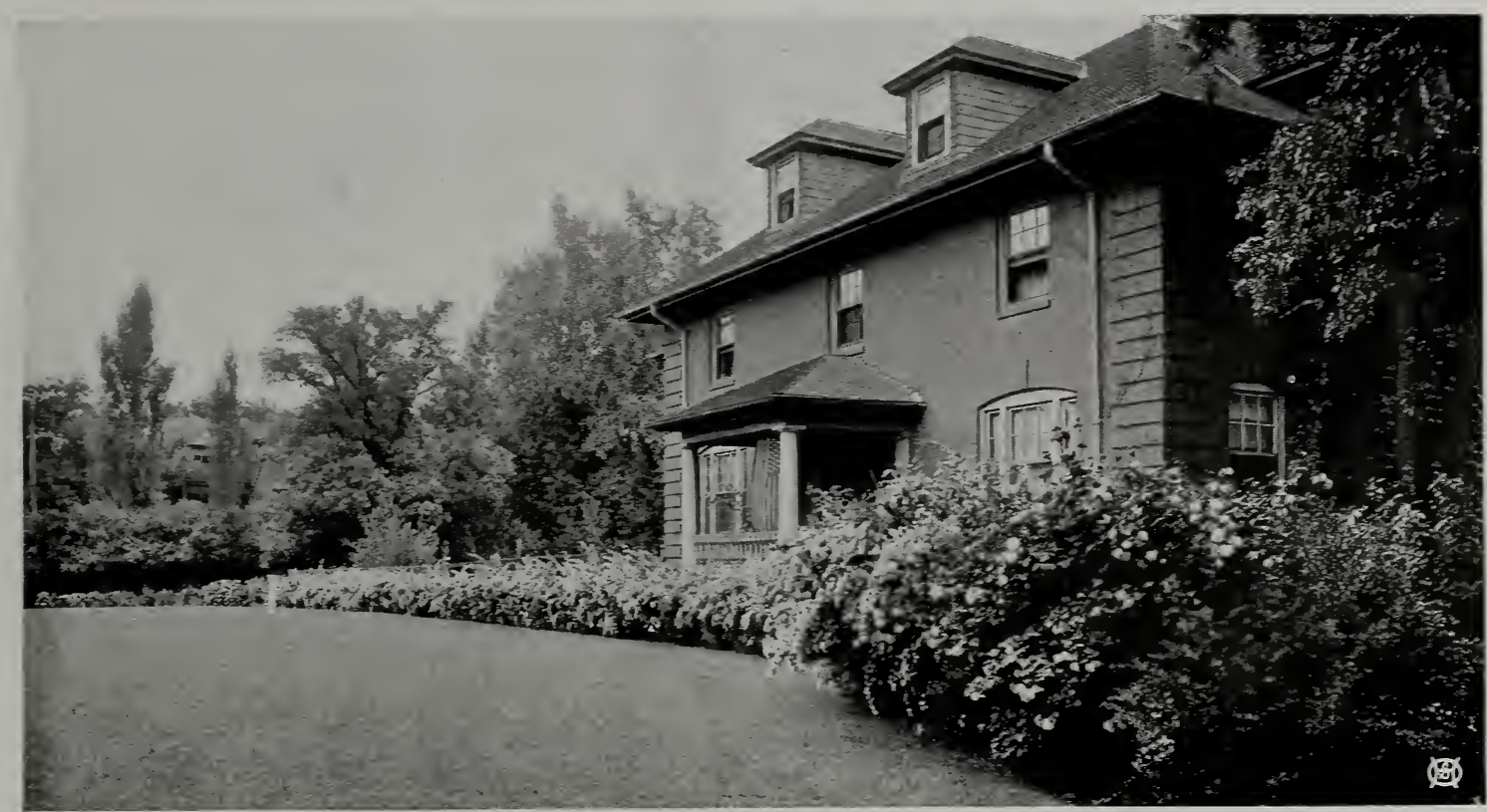

For a border or division between lots, there is nothing more beautiful or graceful than Spiraea Van Houttei or Bridal-Wreath

Cotoneaster acutifolia. A dense-growing shrub with dark green, glossy, oval leaves. The best hedge plant for the Northwest. Perfectly hardy and resembles Privet, which is used so extensively in the East but which is not hardy here. This is a new shrub coming from Siberia some years ago, and have but a few thousand plants that are ready for planting, but predict it is the coming hedge plant for this section.

2 to $3 \mathrm{ft}$., transplanted.

3 to $1 \mathrm{ft}$., transplanted.

Per 10 Per 100 $\$ t 00 \$ 3500$

$500 \quad 4000$

Dogwood, Red-twigged (Cornus Sibirica alba).

2 to $3 \mathrm{ft}$., nursery row

2 to $3 \mathrm{ft}$., transplanted

$\$ 300 \quad \$ 2500$

3 to $4 \mathrm{ft}$., transplanted

$\begin{array}{llll}400 & 30 & 00\end{array}$

4 to $5 \mathrm{ft}$., trans., extra-heary, bushy

$\begin{array}{llll}5 & 00 & 40 & 00\end{array}$

$700 \quad 6000$

Honeysuckle, Red Tartarian (Lonicera Tatarica). 2 to $3 \mathrm{ft}$., nursery row.

2 to $3 \mathrm{ft}$., transplanted

$\$ 300 \$ 2500$

3 to $4 \mathrm{ft}$., transplanted.

$\pm 00 \quad 3000$

4 to $5 \mathrm{ft}$., transplanted.

$500 \quad 4000$

7006000

Olive, Russian (Elaeagnus argentea).

18 to 24 in., nursery row.

18 to 21 in., transplanted.

$\$ 200 \$ 1700$

2 to $3 \mathrm{ft}$., transplanted.

$250 \quad 2000$

3 to $4 \mathrm{ft}$., transplanted.

$\begin{array}{llll}3 & 00 & 25 & 00\end{array}$

$500 \quad 4000$

Privet, California (Ligustrum ovalifolium).

2 to $3 \mathrm{ft}$., nursery row.

$\$ 250 \$ 2000$

3 to $\neq \mathrm{ft}$., nursery row .

$300 \quad 2500$

Privet, Ibota (Ligustrum Ibota).

2 to $3 \mathrm{ft}$., transplanted ......... \$3 $00 \$ 2500$

3 to $4 \mathrm{ft}$., transplanted.

$3 \quad 50 \quad 3000$

Privet, Regel's (Ligustrum Regelianum).

18 to 21 in., nursery row....... \$2 $50 \$ 2000$

2 to $3 \mathrm{ft}$., nursery row......... $300 \quad 2500$

Quince, Japan (Cydonia Japonica).

18 to $2 t$ in., nursery row........ \$2 $50 \$ 2000$

18 to 24 in., transplanted......... $300 \quad 2500$

2 to $3 \mathrm{ft}$., transplanted........ 3503000
Rosa rugosa (Japanese Rose).

12 to 18 in., nursery row

18 to 24 in., transplanted

2 to $3 \mathrm{ft}$., transplanted.

Per 10 Per 100 $\$ 300 \$ 2500$ $\pm 00 \quad 3500$

$500 \quad 4000$

Spiraea Van Houttei. One of the most desirable shrubs known.

18 to $2 \frac{1}{1}$ in., nursery row

2 to $3 \mathrm{ft}$., nursery row........ $400 \quad 3500$

3 to $4 \mathrm{ft}$., nursery row........ 5 $00 \$ 000$

3 to $4 \mathrm{ft}$., transplanted

$600 \quad 5000$

Siberian Pea (Caragana arborescens).
18 to 24 in., nursery row
2 to $3 \mathrm{ft}$., transplanted.
$\$ 250 \$ 2000$
3 to $4 \mathrm{ft}$., transplanted
$300 \quad 2500$
$500 \quad 4000$

Willow, Golden Russian (Salix ritellina aurea).

2 to $3 \mathrm{ft}$, nursery row.......... \$1 $00 \quad \$ 900$

3 to $4 \mathrm{ft}$., nurser row.......... $150 \quad 1300$

4 to 5 ft., transplanted, bushy... $350 \quad 3000$

Willow, Laurel (Salix pentandra).

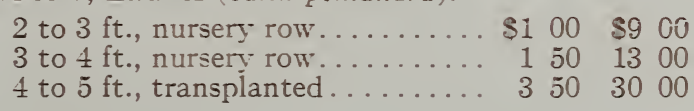

\section{EVERGREEN HEDGES}

Arborvitae, American (Thuya occidentalis).
12 to 18 in., transplanted
18 to 24 in., transplanted
2 to $3 \mathrm{ft}$., transplanted.
$\begin{array}{rrrr}\$ 4 & 00 & \$ 35 & 00 \\ 5 & 00 & 45 & 00\end{array}$
$\begin{array}{llll}5 & 00 & 45 & 00 \\ 7 & 00 & 60 & 00\end{array}$

Spruce, Norway (Picea excelsa).

12 to 18 in., transplanted.

18 to 24 in., transplanted

$\$ \pm 00 \$ 3500$

2 to $3 \mathrm{ft}$., transplanted. .

$\begin{array}{llll}5 & 00 & 45 & 00\end{array}$

7006000

Spruce, White (Picea alba).

12 to 18 in., transplanted

18 to 24 in., transplanted

2 to $3 \mathrm{ft}$., transplanted

$\$ 500 \$ 4500$

$\begin{array}{llll}6 & 00 & 50 & 00\end{array}$

$800 \quad 7000$ 


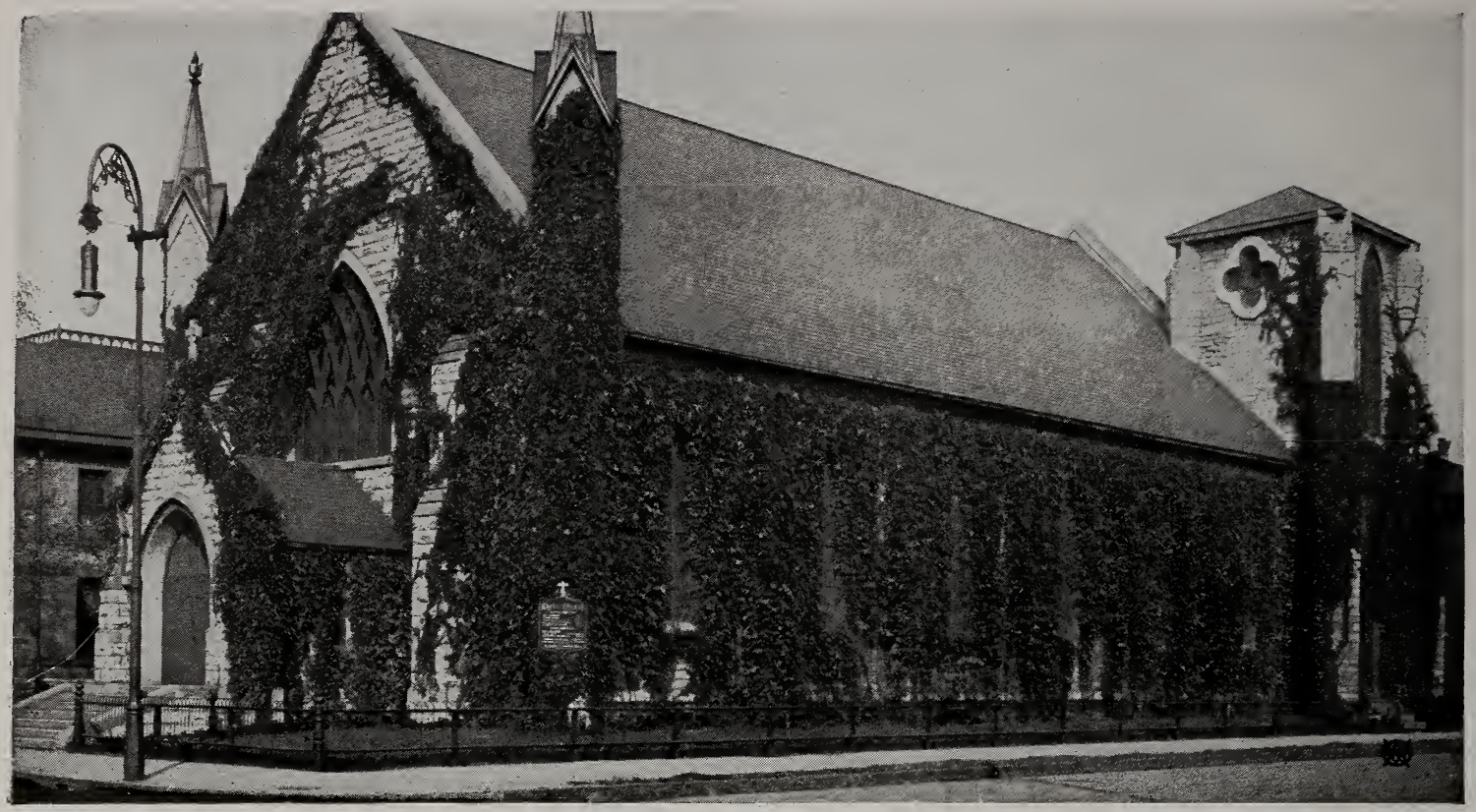

Christ Church, one of St. Paul's landmarks, is almost hidden by the luxuriant growth of Ampelopsis Engelmanni

\section{CLIMBING VINES AND GREEPERS}

CLIMBING VINES are just as necessary in the beautifying of grounds as shrubs, trees or grass; they have their important part in the planting of every place.

Around new buildings, they give shade quickly and are very cooling and cheerful. For verandas or trellises, there is nothing that adds more beauty than a proper selection of vines, and, by covering summerhouses, or trunks of dead trees, a strikingly wild, naturalistic effect is secured.

Ampelopsis Engelmanni (Engelmann's Ivy).

This is the only Ampelopsis that is perfectly hardy in Minnesota, and that will cling to brick, stone or plaster.

2 yrs., nursery row.

2 yrs., transplanted

3 yrs., transplanted

Extra-strong plants

Each 10

$\$ 0 \quad 50 \quad \$ 400$

60,500

$80 \quad 700$

$\$ 1$ to 150

Ampelopsis quinquefolia (Virginia Creeper).
2 yrs., nursery row
2 yrs., transplanted
3 yrs., transplanted
$\$ 050 \$ 400$
$\begin{array}{lll}60 & 5 & 00\end{array}$
$80 \quad 700$

Ampelopsis Veitchii (Boston Ivy).

Not altogether hardy in Minnesota.

2 yrs., strong

3 yrs., strong

$\$ 070 \quad \$ 600$

$80 \quad 700$

Bignonia radicans (Scarlet Trumpet Vine).

2 yrs., nursery row

2 yrs., transplanted

3 yrs., transplanted

Specimen plants.

Celastrus scandens (Bittersweet).

2 yrs., nursery row

2 yrs., transplanted

3 yrs., transplanted

Specimen plants.

$\$ 0 \quad 50 \$ 400$

$\begin{array}{rrr}70 & 6 & 00\end{array}$

$\begin{array}{llll}1 & 00 & 9 & 00\end{array}$

Clematis coccinea (Scarlet Clematis)

2 yrs., strong

3 yrs., strong.

Clematis, Duchess of Edinburgh.

3 yrs., strong.

Potted plants

Clematis Henryi.

3 yrs., strong.

Potted plants

$\begin{array}{llll}\$ 0 & 50 & \$ 4 & 00\end{array}$

$\begin{array}{lll}70 & 6 & 00\end{array}$

$\begin{array}{llll}100 & 9 & 00\end{array}$

Glematis Jackmanii

3 yrs., strong

Potted plants.

$\$ 080 \quad \$ 700$

$\begin{array}{llll}1 & 00 & 9 & 00\end{array}$

$\begin{array}{llll}\$ 1 & 00 & \$ 9 & 00\end{array}$

$\begin{array}{llll}125 & 10 & 00\end{array}$

$\begin{array}{llll}\$ 1 & 00 & \$ 9 & 00\end{array}$

$\begin{array}{llll}125 & 1000\end{array}$

$\begin{array}{llll}\$ 1 & 00 & \$ 900\end{array}$

$\begin{array}{llll}125 & 1000\end{array}$

Clematis, Madame Edouard Andre.

3 yrs., strong.

Potted plants
Clematis Montana rubens.

3 yrs., strong.

Each 10

Potted plants

$\begin{array}{llll}\$ 125 & \$ 1000\end{array}$

Clematis paniculata.

3 yrs., strong

Potted plants.

$\begin{array}{llll}1 & 50 & 12 & 00\end{array}$

$\$ 070 \quad \$ 6 \quad 00$

$\begin{array}{llll}100 & 900\end{array}$

Clematis, Ramona.

3 yrs., strong.

$\$ 100 \quad \$ 900$

Potted plants

$\begin{array}{llll}125 & 1000\end{array}$

Clematis Virginiana.

3 yrs., strong

Potted plants

$\$ 0 \quad 60 \quad \$ 500$

$80 \quad 700$

NOTE.-We guarantee Clematis to reach our customers in good condition, but we cannot agree to replace if they fail to grow.

Dutchman's Pipe (Aristolochia Sipho).

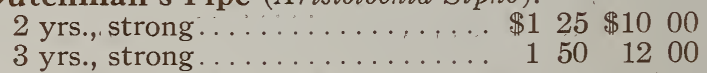

Honeysuckle, Hall's Japan (Lonicera Halliana).

2 yrs., strong, transplanted....... \$0 60 $\$ 500$

3 yrs., strong, transplanted

$\begin{array}{lll}80 & 700\end{array}$

Honeysuckle, Scarlet Trumpet (Lonicera sempervirens).

2 yrs., strong, transplanted...... \$0 70 \$6 00

3 yrs., strong, transplanted....... $100 \quad 900$

Vitis, or Hardy Wild Grape.

2 yrs., strong, transplanted.......\$0 $60 \quad \$ 500$

3 yrs., strong, transplanted.

Specimen plants.

80700

Vitis, Beta (Grape).

2 yrs., strong, transplanted....... $\$ \$ 0 \quad 80 \quad \$ 700$

3 yrs., strong, transplanted....... $100 \quad 900$

Specimen plants.......\$1.50 to 200

Wistaria Chinensis (Chinese Purple Wistaria).

2 yrs., strong, transplanted....... $\$ 100 \quad \$ 900$

3 yrs., strong, transplanted........ $125 \quad 1000$

Wistaria Chinensis alba (Chinese White Wistaria).

2 yrs., strong, transplanted....... $\$ 100 \quad \$ 900$

3 yrs., strong, transplanted........ $150 \quad 1300$ 


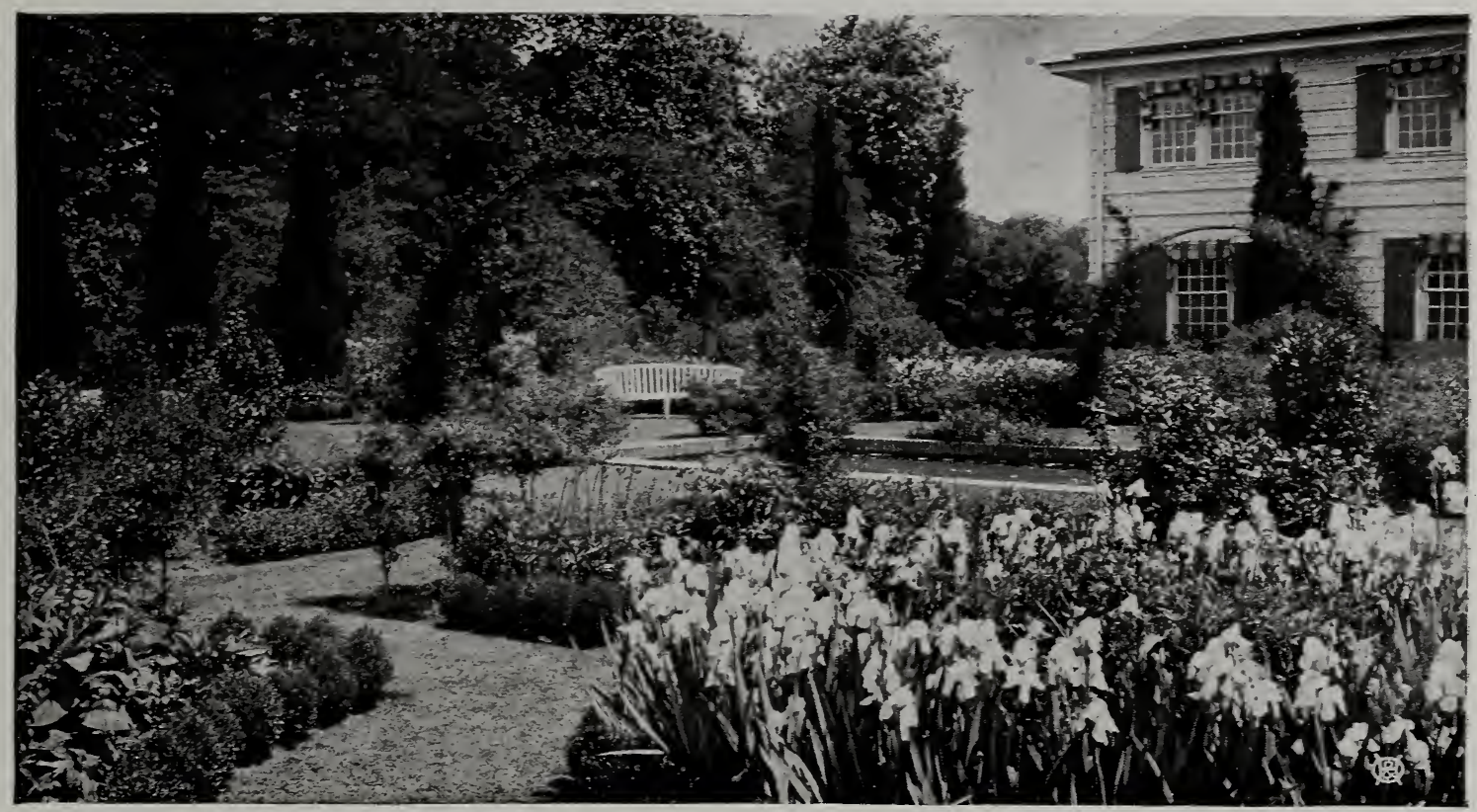

The charm of the old-fashioned garden can be created only by the use of hardy perennials

\section{HARDY PERENNIALS}

7 HE RETURN to popular favor of the old-fashioned flowers infuses into our gardens a peculiar charm, rare beauty and fragrance, that is possible only with hardy perennials. Each day, from the time the tree-buds first burst in the spring until the leaves are gone, the hardy perennial garden is of constant interest and delight. All the old favorites are found here, with the new hybrids and selections.

Ideas differ widely among experts as to the best methods of care and arrangement of the hardy garden or border. Much depends upon the location and size of the grounds at one's disposal, while the owner's individual taste must be carefully considered.

Situation. The most effective location is a good, open border, backed by a hedge, fence, trellis or building. Some of the taller-growing kinds are used as a background; then other sorts of shorter growth, graduating down to the grass line. Perennials are frequently planted among, or in front of shrubs, giving bloom when many of the shrubs are through flowering and supplying a background for the perennial blossoms.

Note. We grow the very finest perennials, and agree to deliver in good condition, but they are sold with the understanding that, should any fail to grow, it is the purchaser's loss. Owing to the low price at which they are sold, we do not guarantee them to grow.

When the price is $25 \mathrm{cts}$. each.

When the price is $30 \mathrm{cts}$. each.

When the price is $35 \mathrm{cts}$. each.

When the price is $40 \mathrm{cts}$. each.

When the price is $\mathbf{5 0} \mathrm{cts}$. each.

6 will be furnished for $\$ 1.25,12$ for $\$ 2.50$

6 will be furnished for $\$ 1.50,12$ for $\$ 3.00$

6 will be furnished for $\$ 1.75,12$ for $\$ 3.50$

Plants priced at 25 cts. are strong, one year old. effective the year after planting.

Achillea, Boule de Neige (Ball of Snow). An improvement on The Pearl; the flowers are of more perfect form. 25 cts.; strong, 30 cts.

A. Millefolium (Rosy Milfoil). Has a rosy red flower on stems from 12 to 18 inches. The foliage is deeply cut. 25 cts.; strong, 30 cts.

A. Ptarmica, "The Pearl.' The plant is covered with a mass of white bloom; used for gardens and shrubbery. 25 cts.; strong, 30 cts.

A. tomentosa (Woolly Yarrow). Handsome, cut foliage and bright yellow. 25 cts.; strong, $30 \mathrm{cts}$.

Aconitum Fischeri. A dwarf variety with large, light blue flowers. 35 cts.; strong, 50 cts.

Aconitum Napellus (Monkshood, or Helmet Flower). Beautiful, rich, deep blue flowers. 35 cts.; strong, 40 cts.

Agrostemma (Rose Campion). Stout, erect-growing plants, with silvery foliage. 25 cts.; strong, 30 cts.

Aegopodium Podograria variegatum (Bishop's Weed). A rapid-growing plant, with neat greenand-yellow variegated foliage. 25 cts.; strong, 30 cts.

Alyssum saxatile compactum (Golden Tuft, or Basket of Gold). Golden yellow. An excellent low-spreading plant for rockery or border. $25 \mathrm{cts}$; strong, 30 cts.

6 will be furnished for $\$ 2.00,12$ for $\$ 4.00$

6 will be furnished for $\$ 2.50,12$ for $\$ 5.00$

"Strong" plants are two years old. All are more

Anemone, Queen Charlotte. Very large, semidouble flowers of La France pink. 30 cts.; strong, $35 \mathrm{cts}$.

A., Whirlwind (Wind Flower). Creamy white. Plant needs cool, moist location. 25 cts.; strong, 30 cts.

Anchusa Italica, Dropmore Variety (Sea Bugloss). A grand improvement on the old Italian Alkanet; one of the best blue perennials. 35 cts.; strong, 40 cts.

A., Opal. Similar to the above, but lustrous, light blue in color. $35 \mathrm{cts}$; strong, $40 \mathrm{cts}$.

Anthemis tinctoria Kelwayi (Hardy Marguerite). Gives a continuous showing, throughout the season. Color of bloom golden yellow. 25 cts.; strong, $30 \mathrm{cts}$.

Aquilegia Canadensis (Columbine). A strong grower and free bloomer. An old favorite. 25 cts.; strong, 30 cts.

A. chrysantha (Golden-spurred Columbine). Color golden yellow. Desirable to plant in partially shady places. 25 cts.; strong, 30 cts.

A. caerulea (Rocky Mountain Columbine). Color pure blue. $25 \mathrm{cts}$; strong, $30 \mathrm{cts}$. 
A. Californica hybrida. Long-spurred flowers in a variety of coloring such as yellow, pink, flesh, red, etc. These are very attractive and more beautif ul than the standard types. $35 \mathrm{cts}$.; strong, $40 \mathrm{cts}$.

Arabis alpina (Rock Cress). A very low-spreading plant, completely covered with pure white flowers. 25 cts.; strong, 30 cts.

Armeria formosa (Sea Pink). A fine variety, with deep crimson flowers, blooming through the summer. 25 cts.; strong, 30 cts.

A. Laucheana rosea. Bright rose. 25 cts.; strong, 30 cts.

Artemisia lactiflora. Unlike the other varieties, it is a most effective flowering plant. 30 cts.; strong, 40 cts.

Asclepias tuberosa (Butterfly Weed). Compact umbels of brilliant orange-colored flowers. $25 \mathrm{cts}$; strong, 30 cts.

Aster, Hardy (Michaelmas Daisy, or Starwort). We offer a good selection in many colors. 25 cts.; strong, 30 cts.

A. Curtisii. Pale heliotrope; August and September. 25 cts.; strong, 30 cts.

A., Hon. E. Gibbs. Pale lavender. August. 25 cts.; strong, 30 cts.

A., Lorenz. Lavender-blue. Very early. 30 cts. ; strong, 35 cts.

A., Mrs. F. W. Raynor. Large, rich, crimsonpurple flowers. 25 cts.; strong, 30 cts.

A., Novae-Angliae (New England Aster). Blooms late in summer. Color violet-purple. 25 cts.; strong, $30 \mathrm{cts}$.

A., Pegǵy Ballard. Small, semi-double, lavenderblue. 25 cts.; strong, 35 cts.

A., Perry's Pink. Large branched heads; reddish pink flowers. September to October. 25 cts.; strong, 30 cts.

A., Robert Parker. Light blue. September. 25 cts.; strong, 30 cts.

A., Saphir. Soft sky-blue. 25 cts.; strong, 30 cts.

A., Snowflake. Very free; pure white. 25 cts.; strong, 30 cts.

A., White Queen. Fine, pure white. 25 cts.; strong, 30 cts.

Astilbe, Gruno Hybrida. A splendid salmon-pink sort, growing 4 feet. $50 \mathrm{cts}$., strong, $60 \mathrm{cts}$.

A., Moerheimii Hybrida. A wellbranched, erect spike of flowers, having a length of 2 feet and are of a beautiful creamy white. 50 cts.; strong, 75 cts.

A., Salland Hybrida. Same nature as the others, except the color of flower is a distinct red. 50 cts.; strong, 60 cts.

Baptisia australis (False Indigo). Blooms, June and July. Color dark blue. 25 cts. ; strong, 30 cts.

Bocconia cordata (Plume Poppy). Flowers creamy white. Fine for background. 25 cts.; strong, 30 cts.

Boltonia asteroides (False Chamomile). Color white. A strong plant that is covered during the summer and autumn. 25 cts.; strong, 30 cts.

B. latisquama. The same as above, except that the flower is a pale pink. $25 \mathrm{cts}$; strong, $30 \mathrm{cts}$.

Campanula Carpatica (Bellflower, or Harebell). Color blue. Of dwarf habit, especially used for borders of beds or for edging; also for rockery. 25 cts.; strong, $30 \mathrm{cts}$.
C. Carpatica alba. Same description as above, except flower is white. 25 cts.; strong, $30 \mathrm{cts}$.

C. calycanthema (Cup-and-Saucer; Canterbury Bell). Colors mixed-blue, rose and white. $25 \mathrm{cts}$; strong, 30 cts.

C. glomerata (Clustered Bellflower). Blooms all summer. Color violet-blue. 25 cts.; strong, 30 cts.

C. Medium (Canterbury Bells). These come in blue, rose, white, and choice mixed colors. 25 cts.; strong, 35 cts.

C. persicifolia (Peach Bells). Blue and white flowers. 25 cts.; strong, 35 cts.

C. pyramidalis (Chimney Bellflower). The most conspicuous of all the Campanulas, forming a perfect pyramid. $25 \mathrm{cts}$.; strong, $35 \mathrm{cts}$.

Centurea montana (Perennial Cornflower). Large, violet-blue flowers from July to September. 25 cts.; strong, 30 cts.

Chrysanthemum Leucanthemum fl.-pl. A double-flowering Daisy of this type has long been sought and is now offered. The white flowers, about $2 \frac{1}{2}$ inches in diameter. 50 cts.

G. maximum (Moonpenny Daisy). Blooms July to October. Color white. 25 cts.; strong, 30 cts.

C. hybridum (Shasta Daisy). Blooms all summer. Height 12 to 15 inches. Color white. 25 cts.; strong, 30 cts.

C. hybridum, Alaska. Blooms all summer. Height 12 to 15 inches. Color white. A great improvement over Shasta Daisy. 30 cts.; strong, 35 cts.

Clematis, Shrubby. This type of Clematis is deserving of the greatest popularity.

C. Davidiana. A most desirable variety, with fresh, bright green foliage. $30 \mathrm{cts}$ : strong; 35 cts.
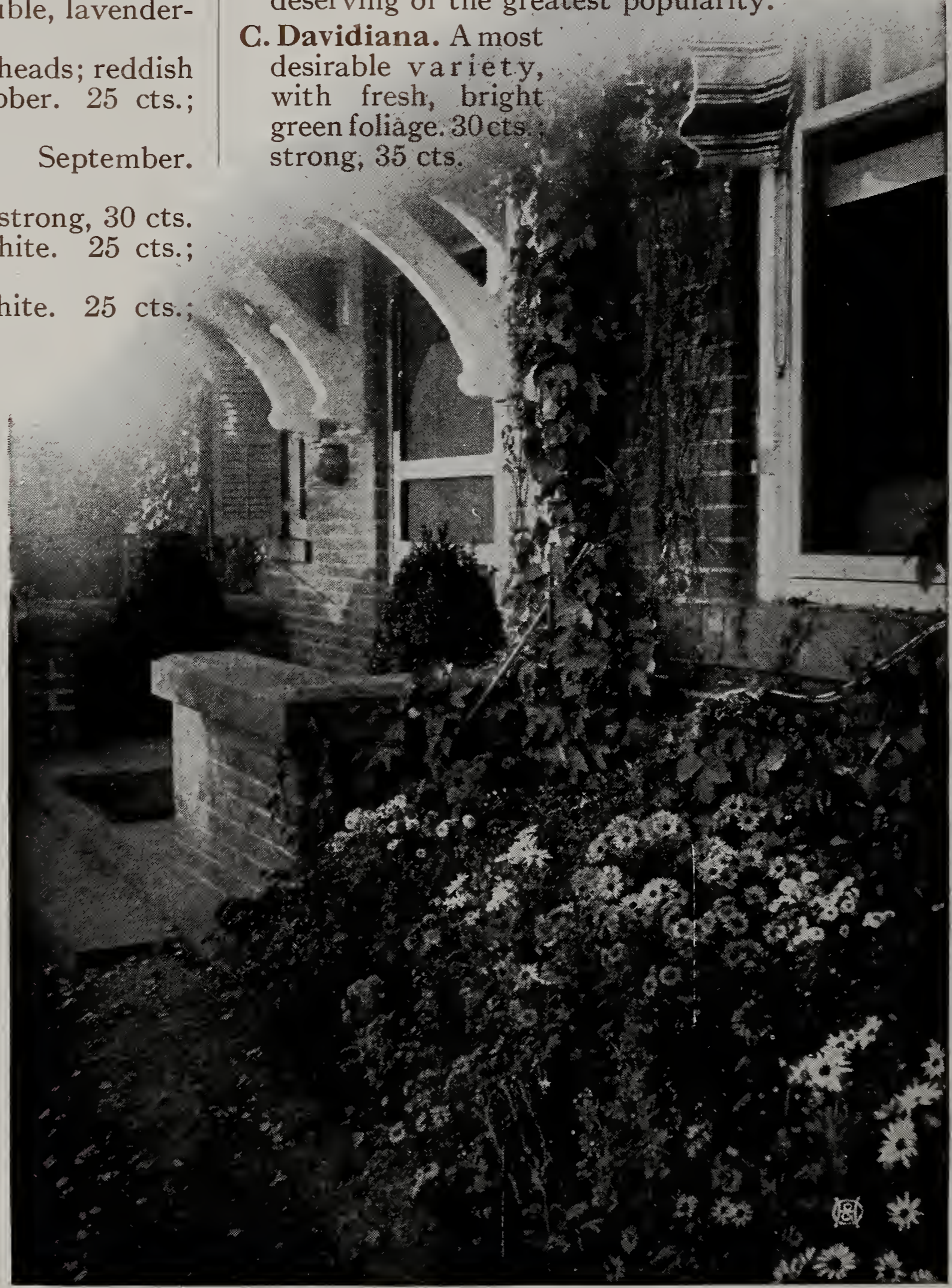

Shasta Daisies shine out effectively in the hardy border 
C. recta. Another fine variety, with handsome, pure white flowers. 30 cts.; strong, 35 cts.

Coreopsis grandiflora. The flowers are a rich golden yellow, of graceful form and invaluable for cutting. 25 cts.; strong, 30 cts.

C. lanceolata (Tickseed). Blooms April to May. Color deep golden yellow. 25 cts.; strong, 30 cts.

C. rosea. Color pink. A low-growing plant. 25 cts.; strong, $30 \mathrm{cts}$.

C. verticillata. Masses of small golden yellow flowers. 25 cts.; strong, 30 cts.

Delphinium Chinense (Larkspur). Blooms June to August. Color light blue. A low-growing variety, with pretty, fern-like foliage. 25 cts.; strong, 30 cts.

D. Chinense album. Similar to the abore except that the bloom is white. 25 cts.; strong, 30 cts.

D. Belladonna. The freest and most continuous blooming of all, never being out of flower from the end of June until cut down by hard frost. The clear turquoise-blue of its flowers is not equaled. 35 cts.; strong, 10 cts.

D. formosum. Color deep blue, with white eye. This variety is unsurpassed. 30 cts.; strong, 35 cts.

D. Moerheimei. The first really white hybrid Delphinium introduced and a decided acquisition. Plants strong and vigorous; 5 feet high. The flowers are purest white with the slightest shading. 50 cts.; strong, 60 cts.

D., Siberian Hybrids. These are the finest strain of mixed hybrids ever offered. 30 cts.; strong, 35 cts.

Dielytra spectabilis (Bleeding-Heart). Flowers

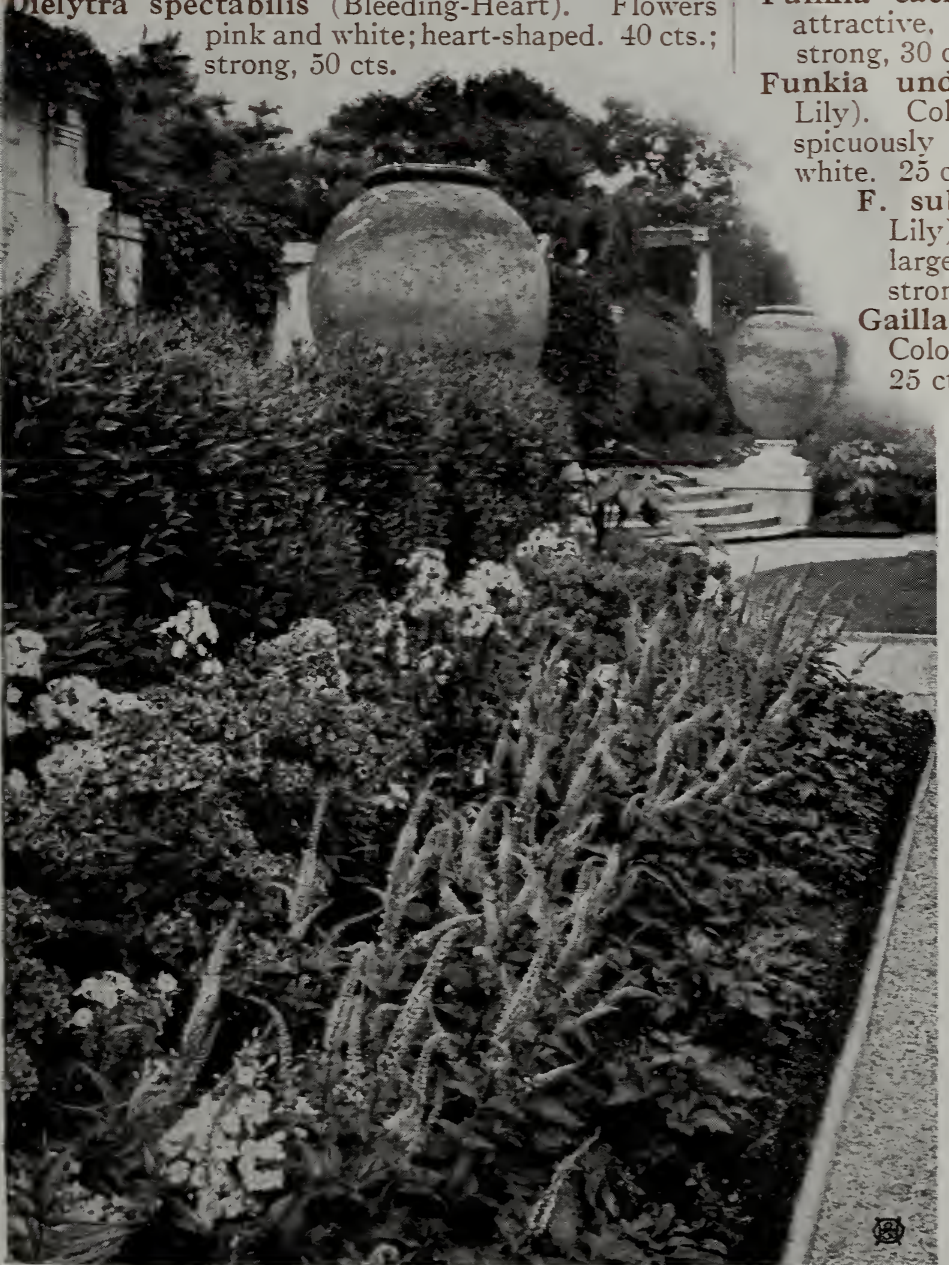

Teronica and Phlox make a charming combination of colors
Digitalis purpurea (Foxglove). Colors, mixed. This old favorite is very well known and very popular. 30 cts.; strong, 35 cts.

D. gloxinaeflora (Gloxinia-flowered Foxglore) A beautiful strain of finely spotted varieties. 30 cts.; strong, $35 \mathrm{cts}$.

Dianthus barbatus (Sweet William). Colors in assortment. $25 \mathrm{cts}$.; strong, $30 \mathrm{cts}$.

D. deltoides roseus (Hardy Pink). These old-time favorites need no description; they bloom all season and are very fragrant. 25 cts.; strong, 30 cts.

D. deltoides albus. Blooms all season. Color white. 25 cts.; strong, 30 cts.

D. latifolius (Hybrid Sweet IVilliam). Color brilliant crimson. A beautiful summer bedding variety. 30 cts.; strong, 35 cts.

D. plumarius (Scotch Pink). Colors mixed. Otherwise same as above. 25 cts.; strong, $30 \mathrm{cts}$.

D. semperflorens (Everblooming Pink). Colors mixed. 25 cts.; strong, 30 cts.

Dracocephalum Virginianum album (Dragon's Head). Terminal clusters of showy, pentstemonlike flowers. Pure white. $25 \mathrm{cts}$; strong, $35 \mathrm{cts}$.

Erigeron Coulteri (Fleabane). Flowers white, with golden centers. 25 cts.; strong, 30 cts.

Eupatorium Fraseri. Strong-growing border plants, suitable for cutting. 25 cts.; strong, 30 cts.

Ferns, Hardy. All of these are attractive, and the majority succeed best when planted on rockwork in a shady situation. 30 cts. each, $\$ 3.00$ per doz., $\$ 20$ per 100.

Funkia caerulea (Plaintain Lily). Color blue attractive, dark green, glossy foliage. $25 \mathrm{cts}$. trong, 30 cts.

dulata variegata (Variegated Day y and beautifully variegated with pure cts.; strong, 30 cts.

subcordata grandiflora (Thite Day ily). Color pure white. Exquisite flowers, arge, long and trumpet-shaped. 30 cts. trong, 35 cts.

(Blanket Flower) 5 cts; strong, 30 cts.

Golden Glow. See Rudbeckia.

Gypsophila paniculata (Baby's Breath). Color white. A favorite delicately formed plant, that produces a profusion of tiny white flowers. 25 cts.; strong, 30 cts.

G. paniculata fl.-pl. The pretty little double, rosette-like flowers of this new variety, which are produced in much-branched panicles. 35 cts.; strong, 50 cts.

G. rosea. A charming pink variety of Baby's Breath. 25 cts. ; strong 35 cts.

Hardy Pinks. See Dianthus

Helenium (Sneezewort). All of these are desirable border plants.

H. au tumnale superbum. Golden yellow flowers during the late summer and fall months. $25 \mathrm{cts}$. strong, 30 cts

H. pumilum magnificum. A most useful perennial, smothered with its golden yellow blossoms. 25 cts.; strong, $30 \mathrm{c}$.

Helianthus giganteus (Hardy Sunflower). A native variety with medium-sized, bright canaryyellow flowers. 25 cts : strong, 30 cts. 


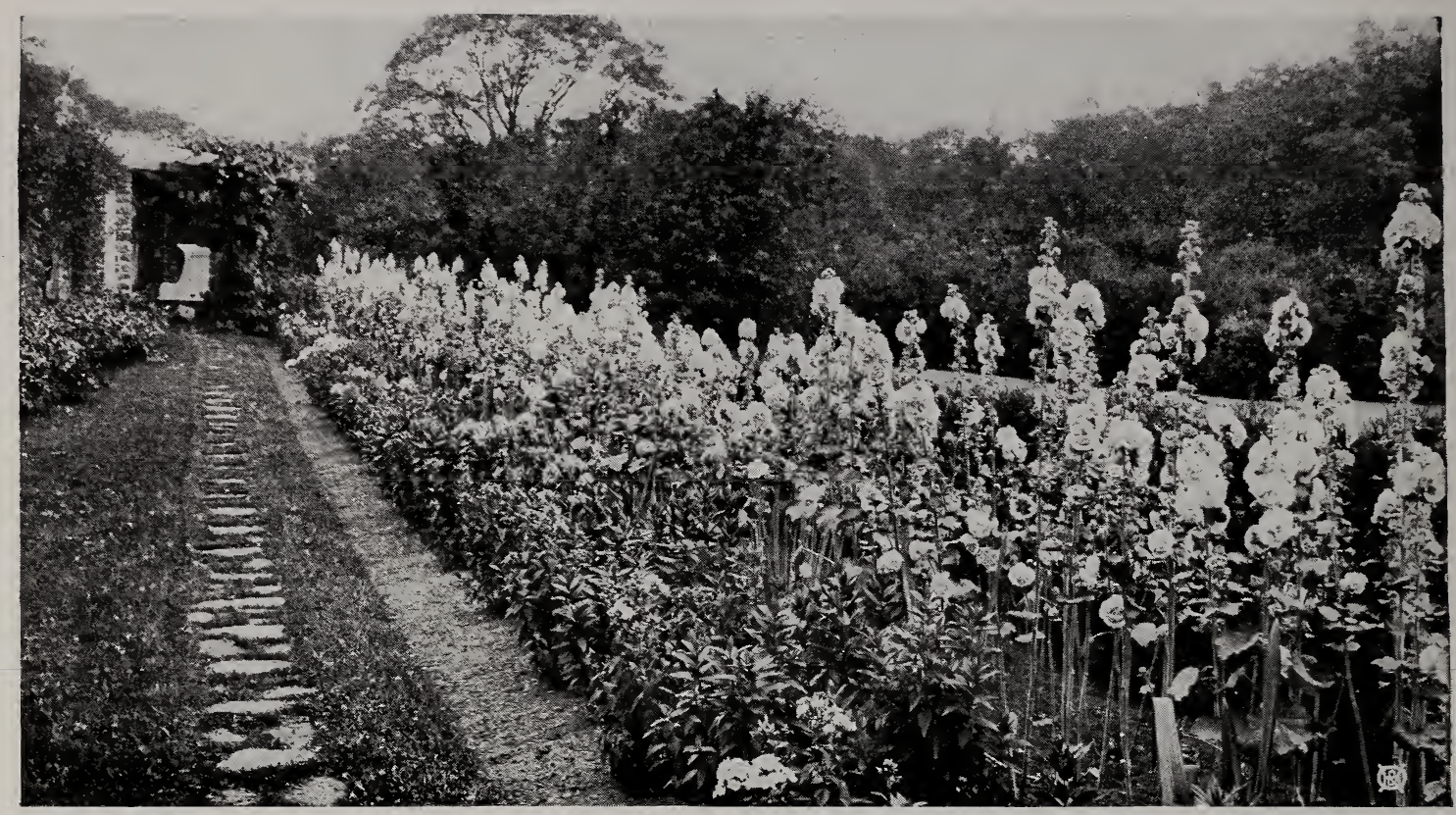

There is something impressive about a stately row of Hollyhocks (see page 22)

H. multiflorus fl.-pl. (Double Hardy Sunflower). Large, double, dahlia-like, golden yellow flowers. 25 cts.; strong, 30 cts.

H., Soleil d'Or. Deep golden yellow, quilled petals, not unlike a dahlia. 25 cts.; strong, 30 cts.

Heliopsis Pitcheriana (Orange Sunflower). Color orange. A continual bloomer from early summer until late in the season. $25 \mathrm{cts}$.; strong, $30 \mathrm{cts}$.

H., Miss Mellish. Large, single, golden yellow flowers, fine for cutting. 25 cts.; strong, $30 \mathrm{cts}$.

H. Zinniaeflora. A new double-flowering form, growing only 24 inches high; golden yellow flowers. 25 cts.; strong, 35 cts.

Hemerocallis aurantiaca. One of the finest flowers whose color throughout is a rich Indian yellow. 25 cts.; strong, 35 cts.

H. flava (Lemon Day Lily). A profusion of large, yellow lilies during the latter part of the summer. 25 cts.; strong, 30 cts.

H. fulva (Tawny Day Lily). Trumpet-shaped flowers. Natural orange color. 25 cts.; strong, 30 cts.

H. Middendorfii. The earliest; flowers bell-shaped, rich chrome-yellow. 25 cts.; strong, 30 cts.

H. Thunbergii. The latest to flower; rich buttercup-yellow. 25 cts.; strong, 30 cts.

Heuchera sanguinea. Most desirable dwarf, compact, bushy plants. $30 \mathrm{cts}$; strong, $40 \mathrm{cts}$.

Hibiscus, Crimson Eye (Marsh Mallow). Color pure white, crimson center. 25 cts.; strong, 30 cts.

H. Moscheutos (Swamp Rose Mallow). Color pink. 25 cts.; strong, 30 cts.

H., Mallow Marvels. A robust type of upright habit; flowers of enormous size; rich shades of crimson, pink, and white. 30 cts.; strong, 35 cts.

Hollyhocks, Double (Althea). Colors mixed. Hollyhocks are undoubtedly among the most ornamental and handsome garden flowers. 25 cts.; strong, 30 cts.

H., Allegheny. Mammoth flowers, wonderfully formed of loosely arranged, fringed petals. 25 cts.; strong, 30 cts.

H., Single. They are usually of freer growth than the doubles. $25 \mathrm{cts}$; strong, $30 \mathrm{cts}$.

Incarvillea Delavayi (Hardy Gloxinia). It produces large, gloxinia-like, rose-colored flowers, which last a long time. 25 cts.; strong, 30 cts.
Lilium auratum (Gold-banded Lily). Color ivorywhite, thickly marked with reddish chocolate dots. 50 cts.; strong, 60 cts.; potted, 75 cts.

L. elegans (Orange Lily). Of dwarf habit; very hardy and produces large, showy flowers in great numbers. $25 \mathrm{cts}$.; strong, $35 \mathrm{cts}$.

L. Myriophyllum (Regale). New. This new type from China, is perfectly hardy in Minnesota. Flower white on inside, with pink tinge on the outside, flower large and deliciously fragrant. Grows 3 to $4 \mathrm{ft}$. $\$ 1.25$ ea. Potted $\$ 1.50$.

L. speciosum album (Japanese Lily). Pure white, with beautiful recurved petals; very fragrant. 50 cts.; strong, 60 cts.; potted, 75 cts.

Lilium speciosum rubrum (Crimson-banded Lily). Flowers are white, with a deep rosy crimson band on each petal. 50 cts.; strong, 60 cts.; potted, $75 \mathrm{cts}$.

L. tigrinum flore-pleno (Double Tiger Lily). A double form of the well-known Tiger Lily. 25 cts.; strong, 35 cts.; potted, 50 cts.

Lily-of-the-Valley (Convallario majalis). Heavy dark green foliage, small, bell-shaped, pure white flowers in pretty racemes. $25 \mathrm{cts}$; strong, $30 \mathrm{cts}$.

Linum perenne (Flax). Color blue. Graceful foliage, large blue flowers. 25 cts.; strong, 30 cts.

Lupinus polyphyllus (Lupine). Grow about 3 feet high, with handsome blue flowers. $25 \mathrm{cts}$; strong, 30 cts.

Lychnis Chalcedonica (London Pride). Color orange-scarlet. $25 \mathrm{cts}$; strong, $30 \mathrm{cts}$.

L. Haageana. Flowers nearly 2 inches across, of brilliant scarlet; hardy and easily grown. 25 cts.; strong, 30 cts.

Lythrum roseum superbum (Loosestrife). A vigorous perennial, with spikes of bright rose flowers. 25 cts.; strong, 30 cts.

Mentha spicata (Spearmint). This is the hardy Spearmint, used largely for seasoning and making sauce. 25 cts.: strong, 30 cts.

Monarda didyma (Oswego Tea). Great clusters of brilliant scarlet flowers. 25 cts.; strong, 30 cts.

M., Cambridge Scarlet. Brilliant crimson-scarlet. 25 cts.; strong, 30 cts.

Myosotis palustris semperflorens (Forget-menot). Clusters of dainty blue flowers; useful in shady border and for forcing. 25 cts.; strong, 30 cts. 


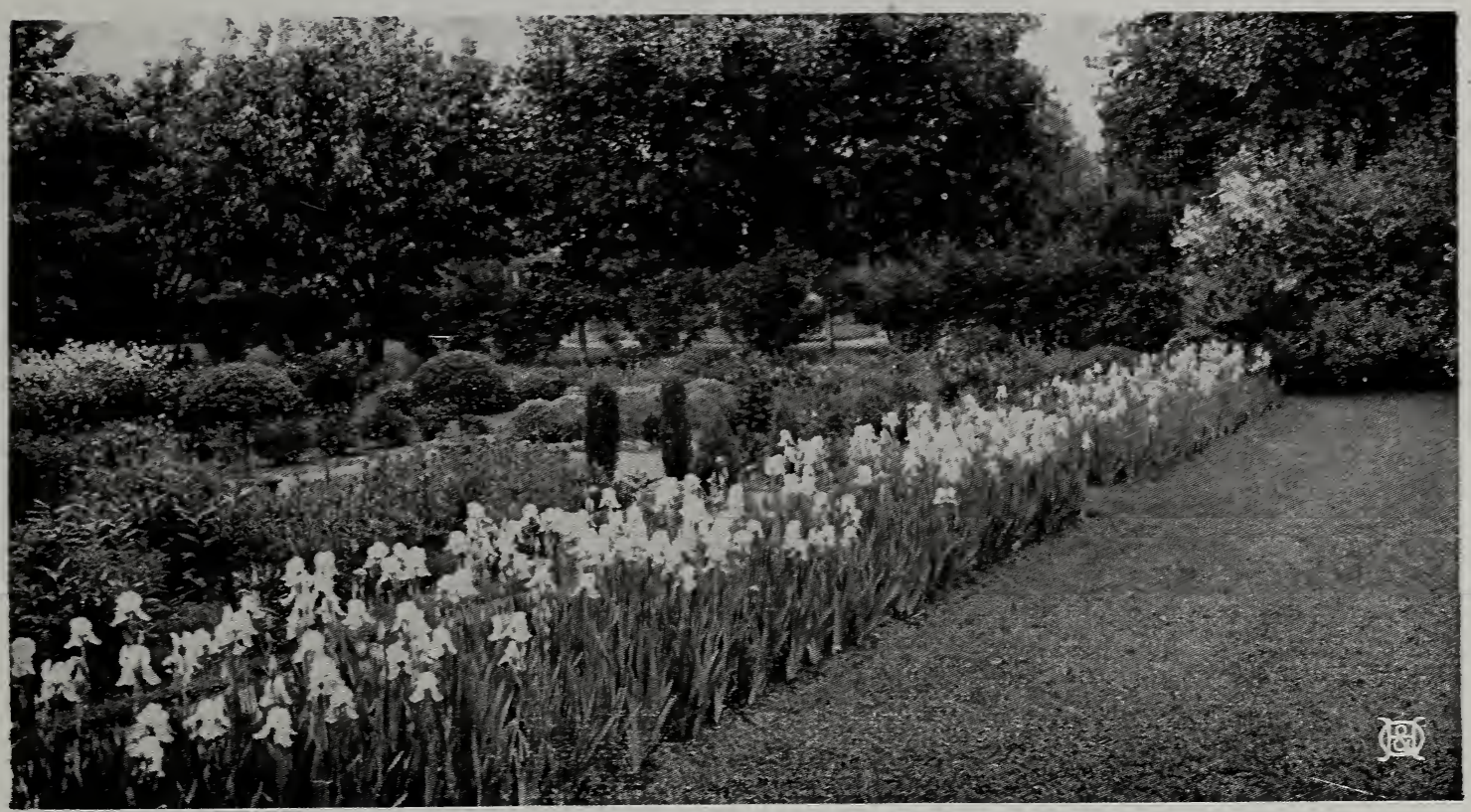

The garden Iris rivals the Orchid in dainty coloring and markings

Pachysandra terminalis. A trailing plant 6 to 8 inches high, forming broad mats of bright glossy green foliage. 25 cts.; strong, 30 cts.

Papaver orientale (Oriental Poppy). Scarlet flowers with a center spot as black as night. 25 cts.; strong, 30 cts.

P. nudicaule (Iceland Poppy). Colors mixed. The cup-shaped flowers. 25 cts.; strong, 30 cts.

Pentstemon barbatus Torreyi (Beard Tongue) A stately, brilliant-flowering perennial. 25 cts. strong, 30 cts.

Phalaris arundinacea variegata (Ribbon Grass). Large, variegated foliage. 25 cts.; strong, $30 \mathrm{cts}$.

Physostegia Virginica (False Dragon-Head). Grows into a dense bush, covered with heath-like, pink, tubular flowers. 2 j cts., strong, $30 \mathrm{cts}$.

P. alba. I fine pure white variety of the above. 25 cts.; strong, 30 cts.

P. rubra. Beautiful soft pink flowers in spikes. 25 cts.; strong, 30 cts.

P. speciosa. A tall form, with bright pink, showy flowers. $25 \mathrm{cts}$.; strong, $30 \mathrm{cts}$.

Platycodom album (Japanese Bellflower). Color white. 25 cts.; strong, 30 cts.

P. grandiflorum. Deep blue, cupped, star-shaped flowers. 25 cts.; strong, 30 cts.

P. Mariesii. Color blue. Similar to Grandiflorum but flowers are deeper blue. 25 cts.; strong, $30 \mathrm{cts}$.

Polygonum cuspidatum (Knotweed). A vigorous growing plant, with large, heart-shaped foliage and innumerable racemes of white flowers. 25 cts.; strong, 30 cts.

Pyrethrum roseum (Feverfew). Very beautiful, double flowers that range in color from pure white and the various shades of pink and red to deep purple. 25 cts.; strong, 30 cts.

P. uliginosum (Great Ox-eye Daisy). White with bright yellow center; long stems. 25 cts.; strong, $30 \mathrm{cts}$

Ranunculus repens (Buttercup). A very freegrowing creeper, with double yellow flowers. 25 cts.; strong, 30 cts.

Rudbeckia laciniata (Golden Glow). Color yellow. 25 cts.; strong, 30 cts.

R. maxima. A rare and attractive variety, bright yellow flowers. $25 \mathrm{cts}$; strong, $35 \mathrm{cts}$.

R. Newmanii. Dark orange-yellow flowers. 25 cts. : strong, 30 cts.

R. triloba. Medium-sized yellow flowers with brown disk. 25 cts.; strong, 30 cts.
Salvia Pitcheri. The flower is sky-blue, blooms in great profusion. $25 \mathrm{cts}$; strong, $3 j \mathrm{cts}$.

Sedum acre (Golden Mass). Color golden. A low carpet plant, splendid for rockeries. $2 j \mathrm{cts}$; strong, 30 cts.

Sedum spectabile (Brilliant Stonecrop). Color rose. Of erect habit and the finest of the Sedums 25 cts.; strong, 30 cts.

Shasta Daisy. See Chrysanthemum, page 20.

Stokesia cyanea (Cornflower Aster). Color deep blue. Produces a succession of large, double, blue flowers. 25 cts.; strong, 30 cts.

Statice latifolia (Sea Lavender). The minute bright blue flowers are produced in broad heads. 25 cts.; strong, 30 cts.

Spiraea Filipendula fl.-pl. (Double-flowered Meadow Sweet). Numerous corymbs of double white flowers. $25 \mathrm{cts}$; ; strong, $30 \mathrm{cts}$.

S. Japonica. Large panicles of white, feathery flowers; 2 feet. 25 cts.; strong, 30 cts.

S. palmata (Crimson Meadow Sweet). One of the most beautiful hardy plants. 25 cts.; strong, 30 cts.

Thalictrum dipterocarpum. A pretty distinct species flowers of charming shade. 50 cts.; strong, 60 cts.

Valeriana officinalis (Hardy Garden Heliotrope) Produces showy rose-pink heads of flowers. 2 cts.; strong, 30 cts.

Veronica longifolia. Flowers deep blue on long spikes. 2 j cts.; strong, 30 cts.

V. spicata (Speedwell). Color blue. Blooms continuously throughout the summer. 25 cts.; strong, 30 cts.

$V$. Virginica. Tall-growing, with large and noticeably distinct spikes of white flowers. $25 \mathrm{cts}$. each; strong, 30 cts.

Viola (Violets). Many of the hardy forms of this dwarf species are easily grown, and should be more generally cultivated.

V. cornuta (G. Wermig). A variety of the tufted Pansy forming clumps that bloom the entire season. 2 j cts.; strong, $3 \check{\mathrm{cts} .}$

V., Hardy Russian. A robust-growing variety with large, single, fragrant, deep blue flowers. 2 ǰ cts.: strong, 30 cts.

Yucca filamentosa (Adam's Needle). Color white. A charming plant to group in the hardy flowerborder. 30 cts.; strong, 50 cts. 


\section{PEONIES}

TVER popular in our grandmother's garden as the "Piney." Today, with hundreds of improved sorts, the Peony rivals the rose in brilliant coloring, sweet fragrance, and perfection of flower. It is adapted to almost any garden soil and is extremely hardy in the Northwest.

\section{WHITE PEONIES}

\section{Alba sulphurea. Large,} creamy white bomb, very massive. Divided roots, 60 cts. each; clumps, $\$ 1.50$ to $\$ 2.50$.

Couronne d'Or. Large blooms of ivory-white, with a circle of yellow. $75 \mathrm{c}$ ea.; clumps, $\$ 1.50$ to $\$ 3$.

Duchesse de Nemours. The guard petals are extra large, center is full; color is the clearest transparent white. $75 \mathrm{c}$ ea.; clumps, $\$ 1.50$ to $\$ 3$.

Festiva. Fine, very full, shell-formed bloom on strong stems; color fine ivory-white. 50 cts. each; clumps, $\$ 1$ to $\$ 2$.

Festiva Maxima. Probably the greatest Peony ever grown. The immense blooms, 7 or 8 inches in diameter, on strong stems, and are of the purest paper-white, 75 cts. each; clumps, $\$ 1.50$ to $\$ 3$.

Golden Harvest. Not very tall, but large and one of freest bloomers; color, blush white with creamy white guard. 75 cts. each; clumps, $\$ 1.50$ to $\$ 3$.

Jeanne d'Arc. Soft pink, center sulphur-white. Very fragrant. 50 cts. each; clumps, $\$ 1$ to $\$ 3$.

La Tulipe. Very large, shell-formed bloom; delicate rose. 75 cts. each; clumps, $\$ 1.50$ to $\$ 3$.

Madame Calot. Pinkish white, tinted with fleshcolor. 75 cts. each; clumps, $\$ 2.50$ to $\$ 3$.

Madame Crousse. Very large, full, well-made flower; color snow-white, center petals edged with bright carmine. 75 cts. each; clumps, $\$ 1.50$ to $\$ 2$.

Madame de Verneville. One of the most charming varieties on the market. The guard petals are pure white, very large and folding over the flower. $\$ 1$ each; clumps, $\$ 2$ to $\$ 3$.

Marie Lemoine. It has immense creamy or ivorywhite blooms, with an occasional carmine tip on center petals. 75 cts. each; clumps, $\$ 1.50$ to $\$ 2.50$.

Queen Victoria. A large, full flower of good substance and color. 50 cts. each; clumps, $\$ 1.50$ to $\$ 2$.

\section{PINK PEONIES}

Alexandre Dumas. Brilliant pink, interspersed with white and salmon. $75 \mathrm{c}$ ea; clumps, $\$ 1.50$ to $\$ 2$.

Albert Crousse. Is colored and formed, with imbricated petals, like a big flesh-pink carnation. $\$ 1.50$ each; clumps, $\$ 3.50$ to $\$ 5$.

Baroness Schroeder. A most delicate, light flesh-pink bud, bleaching when open to white. $\$ 2.00$ each; clumps, $\$ 4$ to $\$ 6$.

Delicatissima. Large flower of very delicate, clear pink. 75 cts. each; clumps, $\$ 1.50$ to $\$ 3$.

Edulis superba. Soft pink, very early. 50 cts. each; clumps, $\$ 1.50$ to $\$ 2$.

Fragrans. One of the oldest, of bright deep pinks, earliest to bloom. 50 cts. each; clumps, $\$ 1.50$ to $\$ 2$.

Lady Leonora Bramwell. Beautiful, large, rosecolored Peony. 50 cts. each; clumps, $\$ 1.50$ to $\$ 2$.

Livingstone. Pale rose, beautiful shadings with some carmine; would be considered a rose type. $\$ 1$ each; clumps, $\$ 2.50$ to $\$ 3.50$.

Madame Boulanger. Light silvery pink, with flesh guard. 75 cts. each; clumps, $\$ 1.50$ to $\$ 2.50$.

Peonia Festiva Maxima

Mme. Camille Bancel. Rich deep pink, lighter toward the center. $\$ 1$ each; clumps, $\$ 2.50$ to $\$ 4$.

Marguerite Gerard. Very pale salmon-pink, fading to almost white. Large compact rose type. $\$ 1$ each; clumps, $\$ 2$ and $\$ 2.50$.

Mons. Jules Elie. Very large, medium compact high crown. Color pale lilac-rose, collar shaded a mber-yellow at base. $\$ 1$ ea ; clumps, $\$ 2.50$ and $\$ 3$.

Therese. Very large; medium compact; rose type; developing later a high crown. Color violet-rose; changing to lilac-white in center. Strong, erect, medium tall; free bloomer; midseason; one of the very best and most desirable varieties. \$6 each.

\section{RED PEONIES}

Auguste Villaume. Immense bloom of American Beauty shade. 75 cts. each; clumps, $\$ 2$ to $\$ 3$.

Delachei. Deep rich crimson-maroon with velvety sheen. 75 cts. each; clumps, $\$ 1.50$ to $\$ 2$.

Edouard Andre. Large, globular bloom; deep crimson. 75 cts. each; clumps, $\$ 2$ to $\$ 3$.

Felix Crousse. Bright red bomb, distinct color, large and massive. $75 \mathrm{cts}$. each; clumps, $\$ 2$ to $\$ 3$.

Karl Rosenfield. Very large, globular, compact, semi-rose type. Dark crimson; very strong; tall; compact grower and free bloomer. $\$ 3$ each.

Lee's Grandiflora rubra. Rich red, resembling an American Beauty rose. 50c ea; clumps, $\$ 1.50$ to $\$ 2$.

Louis Van Houtte. Velvety purple; very dark color, fine form. 50 cts. each; clumps, $\$ 1.50$ to $\$ 2$.

Madame Bucquet. Very dark maroon-purple, beautiful bud, large bloom; very free bloomer. 50 cts. each: clumps, $\$ 1.50$ to $\$ 2$.

Mikado. Japanese type. Dark crimson cup-shaped guard with narrow filamental petals; crimson edged and tipped gold; like a giant red poppy. $\$ 1.50$ each; clumps, $\$ 2.50$ to $\$ 3$.

Officinalis rubra. This is the old-fashioned red, the most brilliant of all red Peonies. $50 \mathrm{cts}$. each; clumps, $\$ 1.50$ to $\$ 2$.

Richardson's Rubra superba. Rich, deep crimson; latest of all. Very sweet. 75 cts. ea.; clumps, $\$ 2$ to $\$ 3$.

Tenuifolia. Flowers double; brilliant crimson; fine, feathery foliage 75 cts. each; clumps, $\$ 1,50$ to $\$ 2$.

\section{UNNAMED PEONIES}

They are useful for mass planting where separate colors are not specially important. 35 and 50 cts. each.

\section{JJAPAN TREE PEONIES}

The Tree Peonies grow in the form of a draw shrub, very free flowering, blooming earlier than the herbaceous sorts. $\$ 2.00$ ea.; $\$ 4$ to $\$ 5.00$ ea. 


\section{IRIS}

$\mathrm{N}$

garden is complete without a good selection of these lovely flowers. Many places are found where they can be used, and they are always attractive and welcome, blooming in early summer, before most of the shrubs. A good border flower for planting along paths, for grouping in beds. You can have blossoms from May till July, by selecting early and late sorts.

\section{GERMAN IRIS}

Alcazar. Violet standard; crimson falls. $\$ 1.00$; strong, \$1.25.

Archeveque. (Arch bishop) (New) Deep velvety-v-iolet. 50 cts.; strong, $75 \mathrm{cts}$.

Aurea. Pure chrome-yellow. 25 cts.; strong, $30 \mathrm{cts}$.

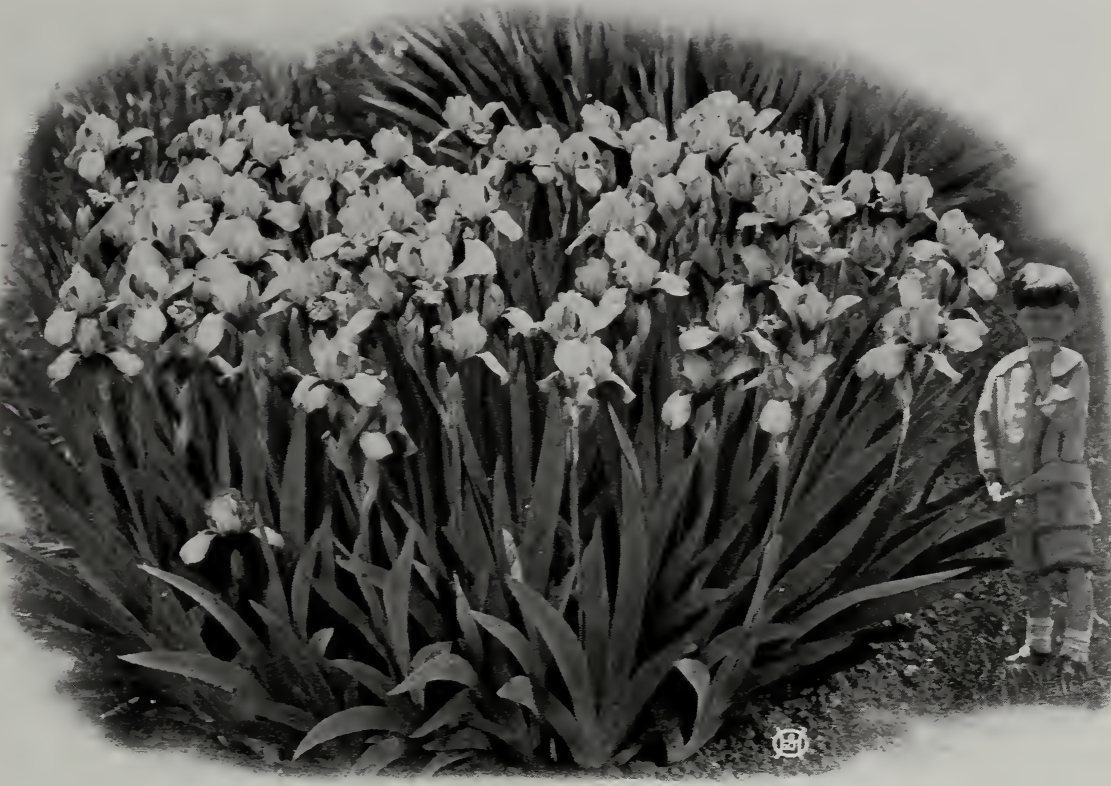

Black Prince. Purple ilac and relvety black. $\$ 1.00$; strong, $\$ 1.25$.

Bridesmaid. White, shaded silvery lilac. 25 cts.; strong, 30 cts.

Caprice. Reddish purple. $30 \mathrm{cts}$; strong, $35 \mathrm{cts}$.

Celeste. Fine satiny blue. $30 \mathrm{cts}$.; strong, $35 \mathrm{cts}$.

Darius. Lemon-yellow, falls purple. 25 cts.; strong, 30 cts.

Edith. Plumbago-blue, falls purple. 2 cts.; strong, $30 \mathrm{cts}$.

Edward Michell. Flower deep wine red. \$1.00; strong, \$1.2j.

Eldorado. Bronze shaded yellow and violet. $50 \mathrm{cts}$; strong, 75 cts.

Fairy. Ivory, changing to pure white. 30 cts.; strong, 50 cts.

Florentina. White and lavender. $25 \mathrm{cts}$; strong, 30 cts.

Her Majesty. Lilac-pink and reddish lilac. 35 cts.; strong, 50 cts.

Honorabilis. Rich mahogany-brown. 25 cts.; strong, 30 cts.

Isolene. Lilac pink and purplish, golden throat. 75 cts.; strong, $\$ 1.00$.

Jeanne d'Arc. Lilac and pure white. 50 cts.; strong, $7 \overline{\mathrm{cts}}$.

Julius Caesar. Amber and deep purple. 25 cts. strong, $30 \mathrm{cts}$.

King of Iris. Lemon yellow and brown and yellow. 75 cts.; strong, $\$ 1.00$.

Kochi Atro-purpuria. (Black Prince) Purple lilac and velvety-black. 30 cts.; strong, 40 cts.

Lohengrin. Deep violet-mauve. 35 cts.; strong, $50 \mathrm{cts}$.

Loreley. Light-yellow, blue and cream. 25 cts.; strong, 30 cts.

Loute. (New). Light blue and heliotrope with reddish purple. \$1.00; strong, \$1.25.

Madame Chereau. White, frilled with violet. 25 cts.; strong, 35 cts.

Monsignor. Blush lavender, with violet and white. 50 cts.; strong, 75 cts.

Oritlamme. Light blue with violet purple. $\$ 1.00$ strong, $\$ 1.25$.

Pallida Dalmatica. Lavender and blue. 35 cts.; strong, 50 cts.

Pallida Mandraliscae. Rich lavender purple. 35 cts.; strong, $50 \mathrm{cts}$.

Penelope. White, speckled violet. 25 cts.; strong, $30 \mathrm{cts}$.

Queen of May. Beautiful Pink. 25 cts.; strong, 30 cts.

Rhein Nixe. White with rich violet purple. $50 \mathrm{cts}$; strong, 75 cts.

Sappho. Violet-blue and velvety purple. $35 \mathrm{cts.;}$ strong, 50 cts.

Sherwin-Wright. Golden yellow. 50 cts.; strong, $75 \mathrm{cts}$.

Tamerlane. Pale violet with deep purple. 75 cts.; strong, $\$ 1.00$.

Unnamed. Assorted. 15 cts.; strong, $25 \mathrm{cts}$.

\section{DWARF IRIS}

Pumila Hybrida. Cyanea. Rich royal purple. 25 cts.; strong, 30 cts.

Pumila Hybrida. Florida. Lemon yellow. 25 cts.; strong, 30 cts.

Pumila Hybrida. Schneekuppe. Pure white. 40 cts.; strong, 50 cts.

\section{JAPANESE IRIS (Iris Kaempferi)}

Commence blooming about the middle of June, and continue for five or six weeks.

Blue Jay. Fine azure-blue, freely mottled. $35 \mathrm{cts.}$; strong, 50 cts.

Eclaire. Largest white. 35 cts.; strong, 50 cts.

Mt. Hood. Light blue, shaded darker. 35 cts.; strong, 50 cts.

Paragon. Rich, velvety purple, center marked with orange. $35 \mathrm{cts}$; strong, $50 \mathrm{cts}$.

Sakata. Lavender-blue, with deeper veinings; minor petals ageratum-blue. $35 \mathrm{cts}$.; strong, $50 \mathrm{c}$.

Spotted Beauty. Large size, double; silky white. 35 cts.; strong, 50 cts.

Victor. Violet-purple, with white veins. $35 \mathrm{cts}$; strong, 50 cts.

\section{SIBERIAN IRIS}

Blue. Flowers similar to the German Iris. Clear, rich blue, but smaller. Strong growers. $25 \mathrm{cts}$.; strong, 30 cts.

White. A fine, pure white form. 25 cts.; strong, 30c.

Snow Queen. Large, snow-white flowers carried on strong stems. $30 \mathrm{cts}$.; strong, $35 \mathrm{cts}$. 


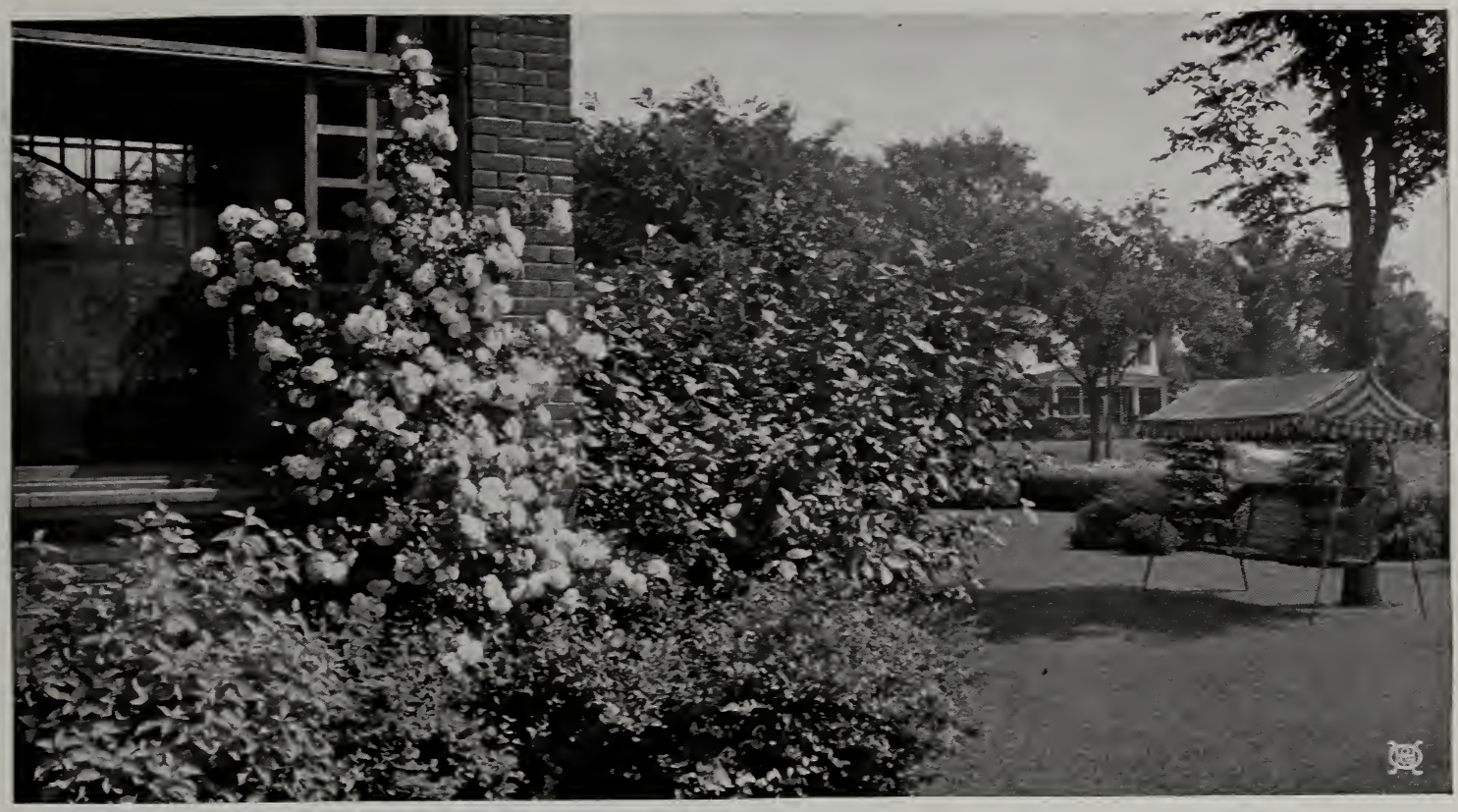

Climbing roses on a south exposure always do well

\section{HARDY ROSES}

D OSES - the name is an inspiration to garden-lovers-are justly classed among the showiest and best plants for decorating the home grounds. No garden is complete without them, no arrangements satisfactory that neglect them; in fact, they are indispensable. Fortunately, it is possible to select from the numerous species and garden forms varieties that are adapted to almost every requirement.

\section{PRICES OF ROSES}

Prices of all Roses, except where noted, are given in the table prices and are made for two-year, strong plants. We make prices for potted plants, they are started and can be planted with a ball of earth, thus as -
suring success under ordinary conditions. Ea. 2 -yr., strong potted plants..... $\$ 100 \quad \$ 900$

\section{HYBRID PERPETUAL ROSES}

Alfred Colomb. Cherry-red.

Anna de Diesbach. Brilliant crimson.

Baron de Bonstetten. Rich dark red.

Captain Christy. Shell-pink, shading dark in center. Capt. Hayward. Crimson-carmine; l'ge perfect form. Clio. Flesh-color, shaded rosy pink center. Eugene Furst. Dark crimson.

Fisher Holmes. Brilliant carmine-crimson. Frau Karl Druschki. Best white Hybrid Perpetual. General Jacqueminot. Brilliant crimson. John Hopper. Bright rose, with carmine center. Louis Van Houtte. Crimson-maroon.

Madame Gabrielle Luizet. A magnificent pink. Magna Charta. Bright pink, suffused carmine.

Margaret Dickson. Pure white; fine form. Marshall P. Wilder. Color cherry-carmine.

Marie Bauman. Bright carmine-red.

Mrs. John Laing. Soft, delicate pink.

Paul Neyron. A beautiful deep rose-color; the largest. Prince Camille de Rohan. A velvety crimson. Ulrich Brunner. Brilliant cherry-crimson.

\section{TEA AND HYBRID TEA ROSES EVERBLOOMING ROSES}

Our list of Hybrid Tea Roses comprises the very best to be had, many of the finest that have been introduced in recent years, and the leaders of the standard sorts.

Strong, 5-inch pot-plants, \$1 each; \$9 for 10 , except where noted.

Augustus Hartmann. Brilliant geranium-red orange; $\$ 1.50$ each, $\$ 12$ for 10 .

Caroline Testout. Bright satiny rose.
Cheerful. New; pure orange. \$2 each, \$18 for 10. Clothilde Soupert. Pearl-white, shading to a pink. Countess of Shaf tesbury. Bright silvery carmine. $\$ 1$ each, $\$ 8$ for 10 .

Duchess of Wellington. Intense saffron-yellow. $\$ 1.25$ ea.

G. C. Waud. Glowing orange-vermillion. \$1.25 ea. Gorgeous. Deep orange-yellow. \$2 each, \$18 for 10. Gruss an Teplitz. Scarlet, shading to velvety crimson. $\$ 1.25$ ea.; $\$ 12.00$ for 10 .

Heinrich Munch. Soft pink; large and full. $\$ 1.25$ ea.

Hermosa. Daintily cupped flowers of pretty pink. Iona Herdman. A pure orange. \$2 ea., \$18 for 10 . Juliet. Outside petals old gold. $\$ 1.25 \mathrm{ea}$.

Lady Mary Ward. Color rich orange, shaded apricot. $\$ 1.25$ each, $\$ 12$ for 10.

La France. Silvery rose, changing to silvery pink.

Kaiserin Augusta Victoria. Creamy white. $\$ 1.25$ ea.

Killarney. Color flesh, shaded white.

Le Progres. Buds golden, pale yellow. $\$ 1.25$ ea.

Los Angeles. Flame-pink, yellow and gold. Each $\$ 2$.

Maman Cochet. Deep rose-pink

Mme. Edouard Herriot. Coral-red, shaded yellow. $\$ 1.25$ each, $\$ 12$ for 10 .

Mme. Jennry Guillemot. Soft shade of yellow. $\$ 1.25 \mathrm{ea}$

Mrs. Andrew Carnegie. White; lemon tinted. $\$ 1.25 \mathrm{ea}$.

Mrs. Aaron Ward. Distinct Indian yellow. $\$ 1.25$ ea.

Mrs. Charles Russell. Rosy-carmine and scarlet. $\$ 1.25 \mathrm{ea}$.

Mrs. Hugh Dickson. Color deep cream with orange. $\$ 2.50$ each, $\$ 22$ for 10 .

National Emblem. Beautiful dark crimson. \$2 each, $\$ 18$ for 10.

Rayon d'Or. Yellow cadmium. $\$ 1.25$ ea.

Richmond. Large; rich velvety crimson. 


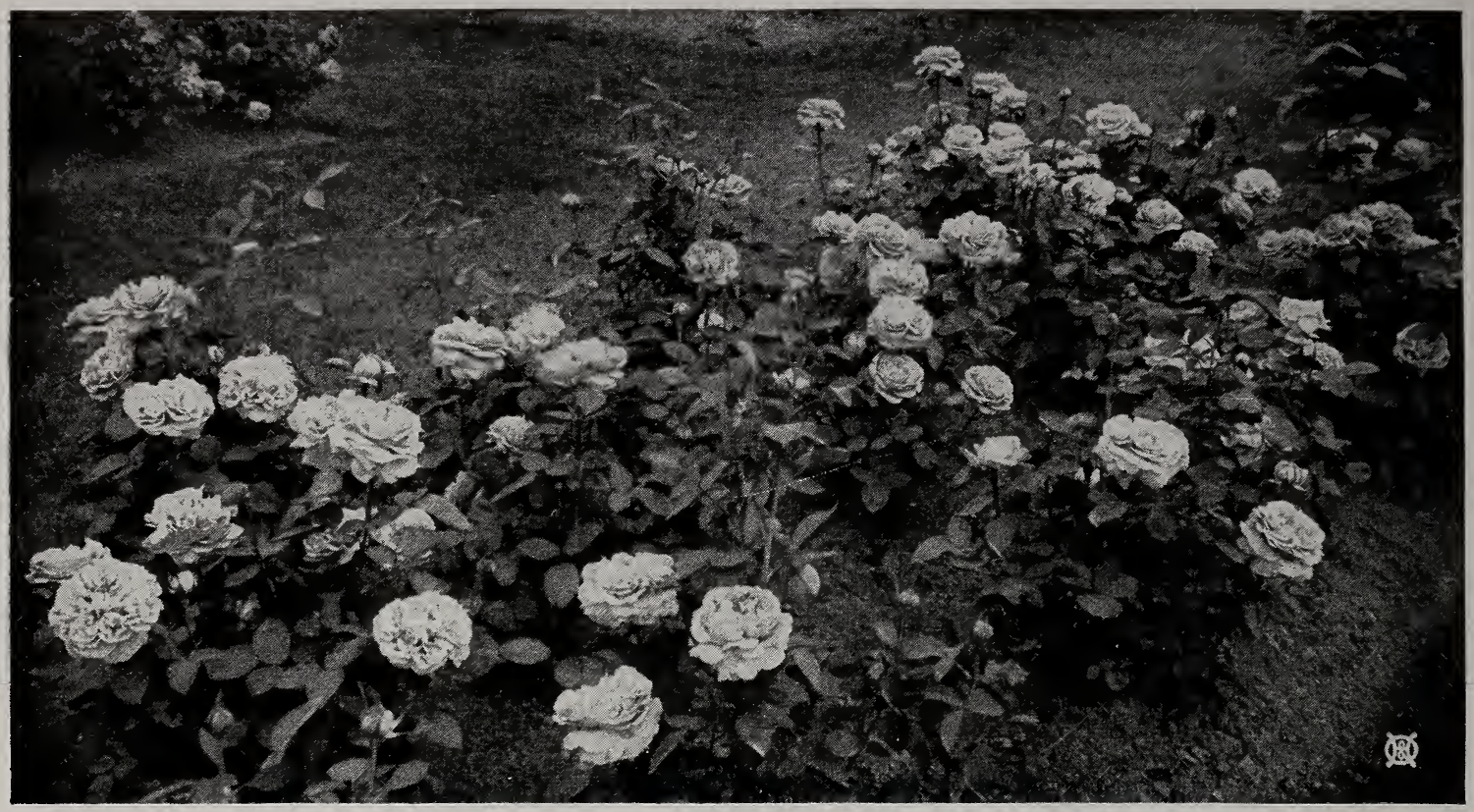

The joy of gardening can be fully realized with a bed of Roses like this

\section{MOSS ROSES}

Price same as Hybrid Perpetuals

Blanche Moreau. Pure white; large.

Crested Moss. Deep pink buds.

Henry Martin. Rich, glossy pink.

Princess Adelaide. Fine reddish blush.

William Lobb. Violet-red; a strong grower.

\section{YELLOW ROSES}

Price, 2-yr., strong, dormant plant s, $\$ 1$ each; $\$ 9$ for 10.

Harrison's Yellow. Semi-double; bright yellow.

Persian Yellow. Deep golden yellow; semi-double.

Soleil d'Or. Orange-yellow to reddish gold. $\$ 1.25$ each.

\section{BUSH ROSES}

This type of Roses is desirable in connection with shrubbery plantings and to be grouped by themselves. They are good for banks, borders, and patchwork. They do not need protection and are of the single type.

2-yr., strong, dormant plants, 60 cts. each; $\$ 5$ for 10.

Blanda (Meadow Rose). Pink flower, red fruit.

Carolina. Pink and come in flat clusters.

Lucida. A fine native, rosy pink.

Multiflora. Pure white blossoms.

Rubrifolia. Reddish purple leaves.

Setigera. The typical Prairie Rose.

\section{CLIMBING ROSES}

2-yr., strong, dormant plants, 75 cts. each; \$7 for 10. Pot plants, $\$ 1.00$ each.

American Pillar. Lovely shade of pink, clear white eye.

Grimson Rambler. The famous crimson-clustered climber.

Dorothy Perkins. Clear shell-pink, borne in clusters.

Dr. W. Van Fleet. Flesh pink. $\$ 1.00$ ea.

Excelsa. Flowers double. Intense crimson-maroon.

Lady Gay. Delicate cherry-pink.

Philadelphia Rambler. An improvement over Crimson Rambler.

Prairie Queen. Bright rosy red.

Tausendschon. Soft pink, later deepening.

\section{RUGOSA ROSES}

2 -yr., strong, dormant plants, $\$ 1$ each; $\$ 9$ for 10 . Agnes Emily Carman. Semi-double, rich crimson. Blanc de Coubert. Pure white, semi-double.

Conrad Ferdinand Meyer. Clear, silvery rose.
Madame Georges Bruant. Free-blooming white. New Century. Rosy pink, with red center.

Nova Zembla. Silvery rose.

Rugosa rosea. Bears pink flowers. $60 \mathrm{cts}$. ea. Rugosa alba. Pure white. 60 cts. ea.

\section{DWARF POLYYANTHA OR BABY} RAMBLER ROSES

This type of Roses has been in existence only a few years. They were first used only as potted Roses, for the Easter trade, but were found excellent for outside planting, blooming constantly through the summer.

2-yr., strong, potted plants, $\$ 1$ each; $\$ 9$ for 10 , except where noted.

Baby Rambler. The dwarf crimson rambler.

Baby Tausendschon. Dwarf and bushy; flesh-pink. Betsy Vannes. Strong grower with fine light green

foliage; double, bright pure red. $\$ 1$ each, $\$ 8$ for 10 .

Erna Teschend orf. A vivid crimson.

Ellen Poulsen. Sweet-scented clusters of dark pink. Jessie. Richmond-red and does not fade.

Mrs. Wm. H. Cutbush. Pink baby rambler.

Orleans. Geranium-red, center of pure white.

WICHURAIANA, MEMORIAL OR EVERGREEN ROSES

2-yr., strong, dormant plants, 75 cts. each; $\$ 7$ for 10 .

Gardenia. Bright yellow flowers.

Manda's Triumph. Pure white, very double.

South Orange Perfection. Similar to the preceding in growth.

Universal Favorite. Vigorous grower. Flowers double.

Wichuraiana. A low, trailing species.

\section{SWEETBRIER ROSES}

The foliage is deliciously scented; the flowers are of the most beautiful tints and produced in great profusion; perfectly hardy.

2-yr., strong, dormant plants, 75 cts. each; $\$ 7$ for 10 .

Amy Robsart. Beautiful deep rose-colored flowers. Anne of Geierstein. Large, deep crimson flowers. Lady Penzance. Soft tint of copper, base yellow. Rubiginosa. The well-known Sweetbrier.

\section{TREE ROSES}

Our Tree Roses are grafted on hardy Rose-stalks, 4 to 5 feet high. Each 10

$2-y r .$, strong potted plants..... $\$ 250 \$ 2300$ 


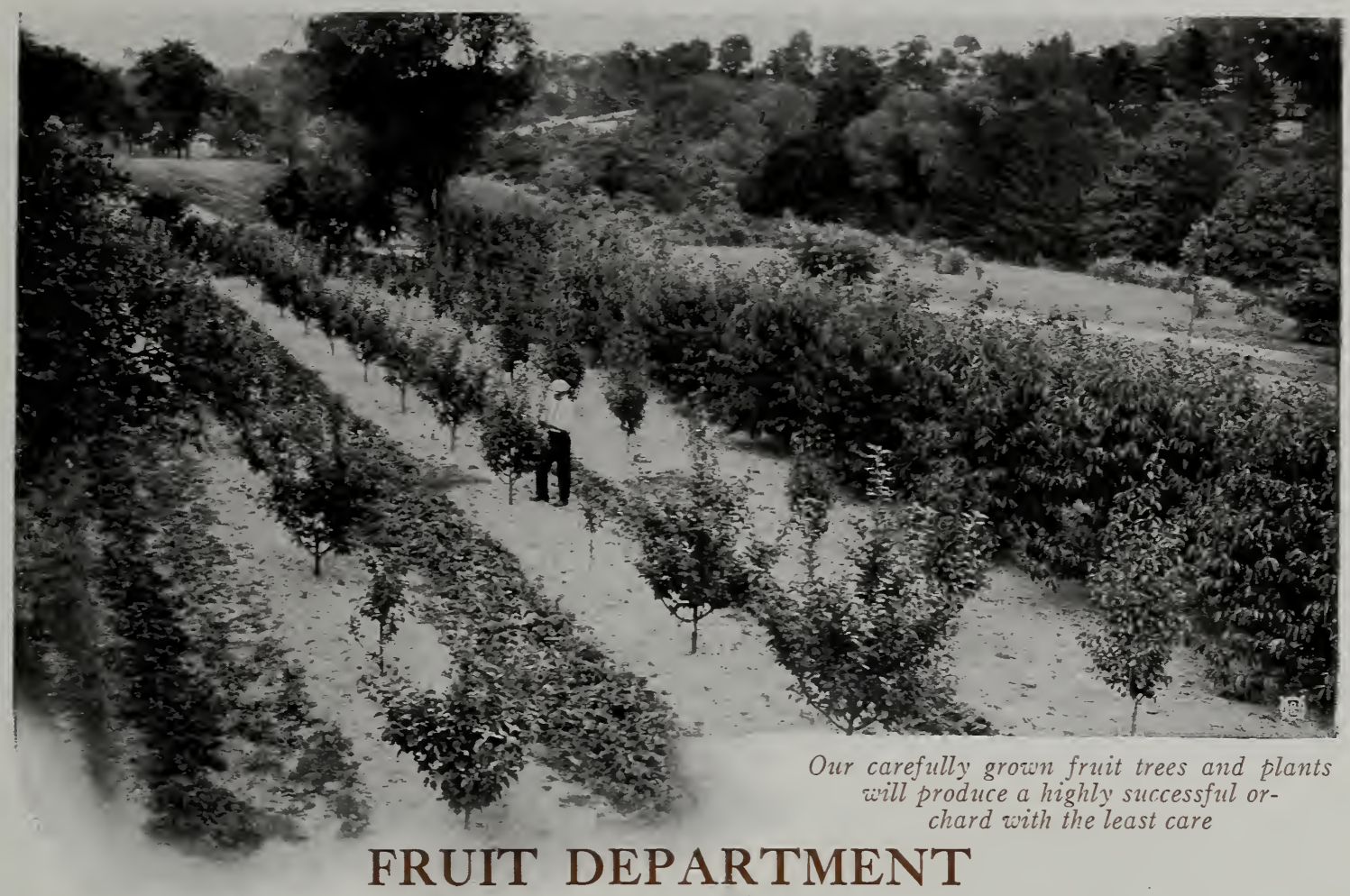

$7 \mathrm{HE}$ growing of hardy fruits has been increasing from year to year, and with the improved methods and improved varieties, together with the growing of the trees in the sections where they are to be planted, so that they have become acclimated to our climate, insures success.

\section{APPLES}

3 and 4 yrs., 5 to $6 \mathrm{ft}$.

3 and 4 yrs., 5 to $7 \mathrm{ft}$.

Extra size, $1 \frac{1}{4}$-in. cal.

Extra size, $1 \frac{1}{2}$-in. cal. .

Extra size, 2 -in. cal..

Extra size, $2 \frac{1}{4}$-in. cal. and up

Trees should be planted about 25 feet apart.

\section{Standard Varieties}

Anisin. A most valuable sort from Russia.

Duchess of Oldenburg. Best early.

Hibernal. Fruits large to very large.

Longfield. Large, yellowish green with red stripes.

Malinda. Rich yellow, with dull blush.

Northwestern Greening. Green, tinted red.

Okabena. A seedling of Wealthy.

Patten's Greening. One of the best keepers.

Wealthy. Fruit dark crimson; flesh crisp and subacid.

Yellow Transparent. Russian origin; early.

\section{CRAB APPLES}

Prices same as Standard Apples.

Early Strawberry. Red striped, excellent for eating. Hyslop. One of the most popular of the Crabs.

Minnesota. Hardy, medium grower; fruit large.

Siberian. Fruit small, round; flavor sour and acid.

Whitney. One of the largest; carmine.

\section{PLUMS}

The class of Plums we offer are those that are perfectly hardy, known as the American type. Much improvement has been accomplished in recent years by seedlings or crossing. Plums should be set in clusters so they will pollenize, as their blossoms are male and female.

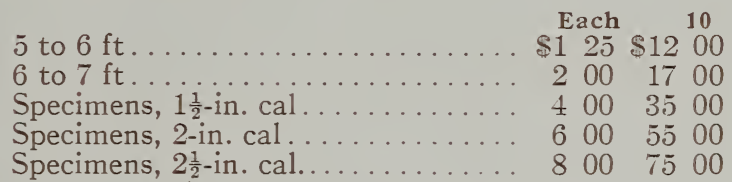

De Soto. Perfectly hardy; a splendid bearer; yellow.

Forest Garden. Hardy; bears profusely.

Hanson Hybrids. Cross between American and Japan Plums. \$1.5j each.

Hawkeye. Very hardy and a strong grower.

Surprise. This is considered the best of the native type of Plums. It is a seedling of Minnesota.

Stoddard. Fruit oblong, oval, large.

Wolf. One of the largest and a perfect free-stone.

\section{CHERRIES}

The Morellos are the only Cherries that are hardy in the Northwest, with the exception of some natives of crosses with the Plum.

4 to $5 \mathrm{ft}$

Each 10

5 to $6 \mathrm{ft}$

Specimen trees

$\$ 125 \$ 1200$

$200 \quad 1 \pm 00$

Early Richmond. Fruit dark red of medium size.

English Morello. Large, dark red, nearly black.

Montmorency. Finest flavored Cherries grown.

Ostheimer. Large, nearly black when ripe.

Wragg. Very similar to English Morellos.

Homer. A valuable seedling, originating in Minnesota, distinctly of the Morello type. 


\section{PLUM-GHERRY}

Compass. This hybrid, a cross between the Miner Plum and the Sand Cherry, has been a great acquisition of the fruit growers of the northern states. Prices same as Plums.

\section{GRAPES}

Along almost any garden fence or walk, there is room for vines to furnish fruit enough for the family, from July to November. For such locations they should be planted from 6 to 8 feet apart and kept cultivated.

\section{BLACK AND BLUE GRAPES}

Beta. Cross between the wild Grape and Moore's Early. Strong, 2 years, 60 cts. each, $\$ 5.00$ for 10 .

Concord. Large, handsome black Grapes. Strong, 2 years, 30 cts. each, $\$ 2.50$ for 10 .

Campbell's Early. A fine new Grape. Strong, 2 years, 60 cts. each, $\$ 5$ for 10 .

Moore's Early. Bunch and berry large. Strong, 2 years, 40 cts, each, $\$ 3.50$ for 10 .

Worden. Ten days earlier than Concord. Strong, 2 years, 35 cts. each, $\$ 3$ for 10 .

\section{RED GRAPES}

Agawam (Rogers' No. 15). Dark red or maroon. Strong, 2 years, 35 cts. each, $\$ 3$ for 10 .

Brighton. Most desirable of the early red Grapes. Strong, 2 years, 35 cts. each, $\$ 3$ for 10 .

Delaware. Superior as a table Grape. Strong, 2 years, 40 cts . each, $\$ 3.50$ for 10 .

\section{WHITE GRAPES}

Green Mountain. Vine strong, vigorous, healthy. Strong, 2 years, 50 cts. each, $\$ 4.50$ for 10 .

Moore's Diamond. Produces compact bunches. Strong, 2 years, 35 cts. each, $\$ 3$ for 10 .

Niagara. The most popular white Grape. Strong, 2 years, 35 cts. each, $\$ 3$ for 10 .

\section{GURRANTS}

A popular and profitable crop in a variety of soils. Its principal insect enemy, the currant worm, is easily kept in check by the liberal use of hellebore, applied immediately upon the first appearance of the worm. Plant 4 feet or more apart.

Prices, except where noted, strong, 2 years, 35 cts. each, \$3 for 10; extra strong, 50 cts. each.

Perfection, New. The color is a beautiful bright red; size as large as or larger than the Fay. Strong, 2 years, 50 cts. each, $\$ 4.50$ for 10 .

Black Naples. Very large; black.

Cherry. Fruit of the largest size, deep red.

Fay's Prolific. Fruit very large; bright red.

Long-Bunch Holland. One of the best late varieties.

Victoria. Large, bright red; long bunch.

White Grape. Very large; yellowish white, sweet.

\section{GOOSEBERRIES}

Gooseberries thrive well on a variety of soils, if well drained and fertile. The cultivation should be thorough, early in the season.

Downing. "The standard of excellence." Strong, 2 years, 35 cts. each, $\$ 3$ for $10, \$ 20$ per 100 .

Houghton. Fruit medium size, red, juicy, sweet. Strong, 2 years, 35 cts. each, $\$ 3$ for $10, \$ 20$ per 100 .

Josselyn. The freest of all Gooseberries from mildew. Strong, 2 years, 40 cts. each, $\$ 3.50$ for 10 .

Pearl. The most prolific Gooseberry. Strong, 2 years, 40 cts. each, $\$ 3.50$ for 10 .

\section{RASPBERRIES}

For field culture, Raspberries should be planted in rows 4 to 6 feet apart, $2 \frac{1}{2}$ to 3 feet in rows, depending on the character of growth of sorts planted.

Strong plants, 15 cts. each, $\$ 1$ for $10, \$ 5$ per 100 , except as noted.

\section{RED AND PURPLE RASPBERRIES}

Columbian. Fruit purple and delicious for table or canning.

Cuthbert. Color deep rich crimson; fruit very firm.

King. Fine for market and home use.

Loudon. Beautiful red. One of the best.

Minnesota No. 4. Hardiest and best for Minnesota. $\$ 1.50$ per $10 ; \$ 7$ per 100 .

St. Regis. Raspberries for four months. That's what you get when you plant St. Regis. $15 \mathrm{cts}$. each, $\$ 1.25$ for $10, \$ 6$ per 100 .

\section{YELLOW RASPBERRY}

Golden Queen. Hardy and very productive.

\section{BLACK RASPBERRIES}

Cumberland. Fruit of uniform size, and larger than any known black Raspberry.

Gregg. One of the best market Raspberries.

Kansas. Strong, vigorous grower.

\section{BLACKBERRIES}

Plant in rows 6 feet apart, the plants 3 feet apart in the rows. Trim with a view to obtaining a crop of excellent berries from a few strong shoots to a plant rather than from many weak ones.

Strong plants, 15 cts. each, $\$ 1$ for $10, \$ 5$ per 100 , except Lucretia.

Ancient Briton. Plant hardy and very productive. Eldorado. This splendid variety is, perhaps, the best ever introduced.

Snyder. One of the hardiest and best-known.

Stone's Hardy. Ripens a little later than Snyder. Lucretia Dewberry. Its berries ripen before raspberries are gone. Strong plants, 15 cts. each, $\$ 1$ for $10, \$ 6$ per 100 .

\section{STRAWBERRIES}

The Strawberry will grow in any good garden soil where the ground has been thoroughly prepared. For family use plant 1 foot apart in the row, the

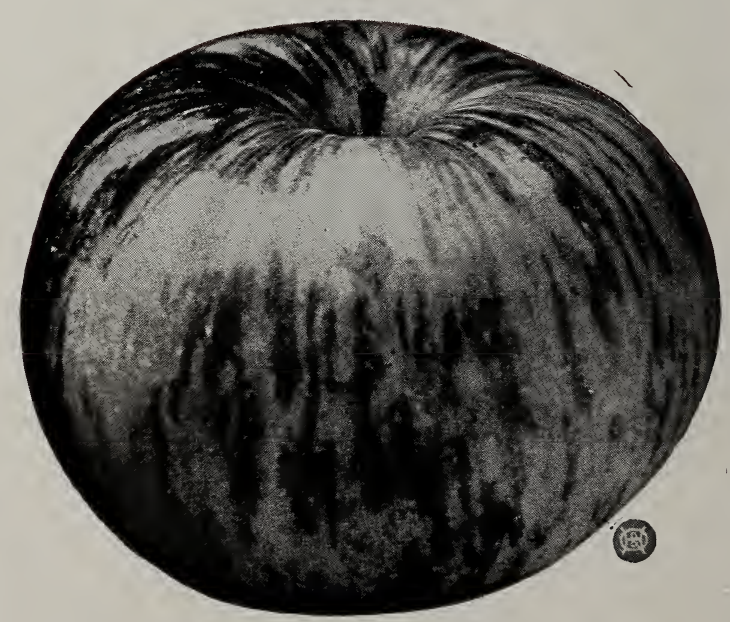

Duchess of Oldenburg Apple 


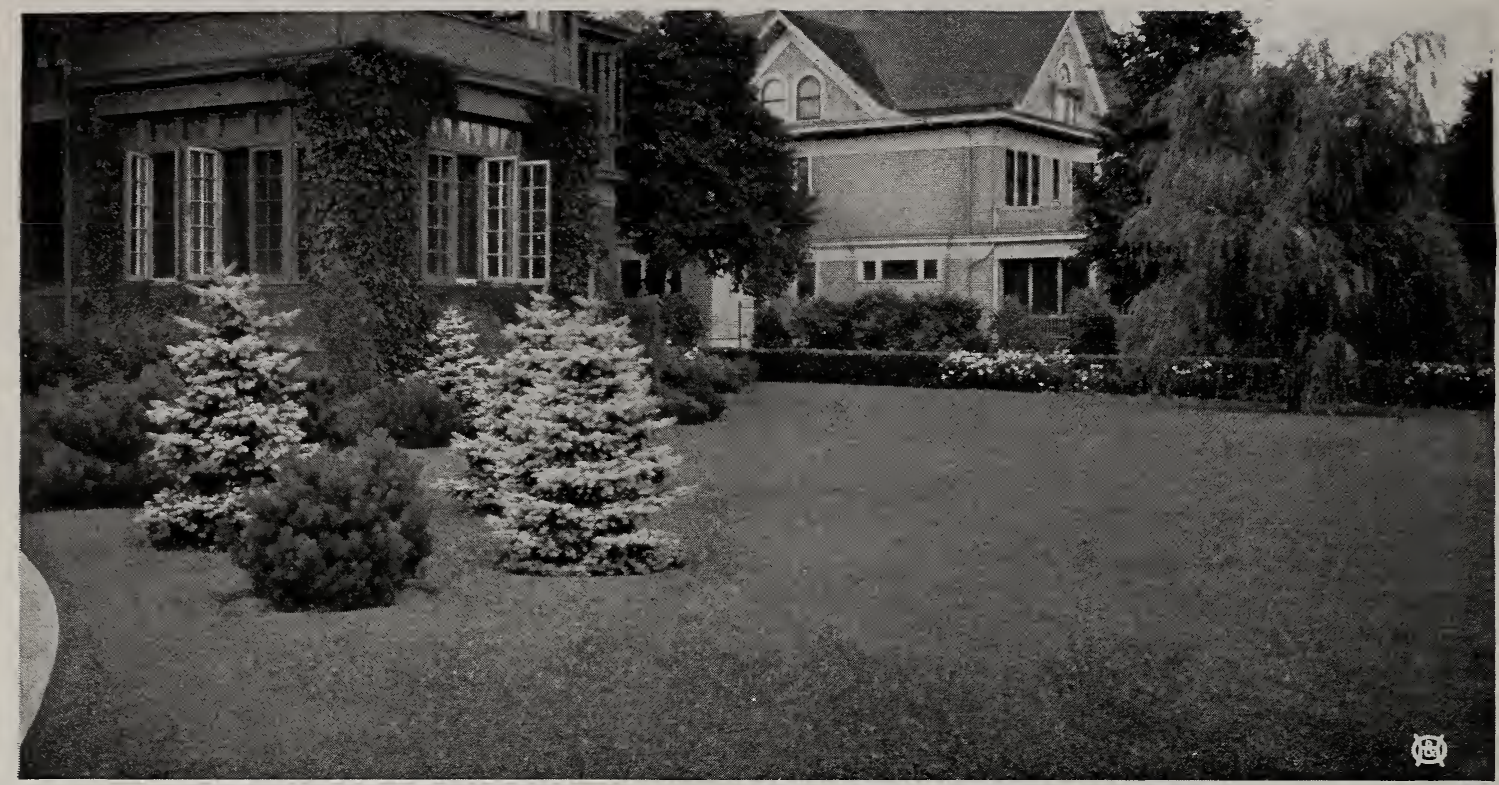

This splendid lawn was made by the H. $\mathcal{E}^{\circ} O$. Service and Velvet Sod Lawn Seed

\section{VELVET SOD LAWN SEED}

$\mathrm{O}$

$\mathrm{NE}$ of the most essential parts of the country place and suburban home is a properly made and wellkept lawn. We have made careful study of the grasses required for best results, and the formulas of our various grass mixtures are based upon these experiments.

The days of laboriously making lawns from sod are rapidly passing away. Good lawns are now made from GOOD GRASS SEED - the essentials are a careful blending of varieties adapted to producing a thick turf with velvety appearance. Each variety in this composition has a special purpose; some make strong, fibrous roots, that take hold on the earth and hold it in position; others, of a creeping nature, quickly fill up the vacant spots; yet other sorts are used for their color value, besides kinds that are able to withstand heavy or excessive rains. Our Velvet-Sod Mixture is composed of the best, strictly pure seeds of hardy lawn grasses from America and Europe. It quickly produces a permanent lawn of rich green and luxuriant growth. If you need grass seed for only a small city yard, or a large lawn of acres, use this mixture.

Quantity of Seed to Sow. One pound of our lawn grass seed will sow 10x20 feet, or 200 square feet. This is heavier than recommended by many seedsmen, but practical experience in making lawns in our landscape department has taught us to use sufficient seed, and the best that can be obtained.

Note. Write for our booklet "The Essential Principles of Lawn Making."

\section{VELVET-SOD MIXTURE}

Our Velvet-Sod Mixture will make a close, thick turf in a very few weeks, which maintains its beautiful, rich green the entire season. We know our mixture to be among the best on the market, and we ask our patrons to carefully consider this before placing their order. The weight of this mixture shows its extra-high quality, and it is entirely free from chaff. Our experience as landscape gardeners has taught us the best Lawn Grass Mixture for parks, cemeteries and private grounds. Lb. 35 cts., 5 lbs., $\$ 1.75,10$ lbs. $\$ 3.25$, bus. (20 lbs.) $\$ 6.00$.

\section{CAPITAL GITY MIXTURE}

This mixture is admirably adapted to all uses, but the quality of the seed is not so high as our VelvetSod Mixture; but, for ordinary sowing, will answer the same purpose. Lb. 30 cts., 5 lbs. $\$ 1.50,10 \mathrm{lbs}$. $\$ 2.75$, bus. (20 lbs.) $\$ 5.00$.

\section{SHADY-SIDE MIXTURE}

This will produce quickly an abundant and even growth of beautiful green grass. The grasses used in making this special mixture are only those that are well adapted to growing in the shade. Lb. 40 cts., 5 lbs. $\$ 2.00,10$ lbs. $\$ 3.75$, bus. (20 lbs.) $\$ 7.00$.

\section{GOLF-LINK MIX'TURE}

This mixture is composed of grasses best suited for golf-links, and is the result of careful experi- ments, as well as careful watching for several years of practical results on golf-links sown with our seed. Lb. 35 cts., 5 lbs. $\$ 1.75,10$ lbs. $\$ 3.25$, bus. (20lbs.) $\$ 6$.

\section{PUTTING-GREEN MIXTURE}

The hardiest and finest low-growing grasses are contained in this mixture. It produces a beautiful and lasting green turf calculated to withstand hard tear and wear. Lb. 50 cts., 5 lbs. $\$ 2.00$, bus. (20 lbs.) $\$ 8.00$.

\section{TERRACE MIXTURE}

A special mixture of grasses for sowing on terraces and hillsides, producing spreading roots, thus preventing heavy rains from washing out. Lb. 35 cts., 5 lbs. $\$ 1.75$, 10 lbs. $\$ 3.25$, bus. (20 lbs.) $\$ 6.00$.

\section{WHITE GLOVER}

The best variety for lawns, as it forms a close herbage and remains green throughout the season. Sow in spring at the rate of six pounds to the acre when sown alone; half the quantity when sown with other grasses. $1 / 2$ lb. 40 cts., lb. 70 cts., 5 lbs. $\$ 3.25$.

\section{KENTUCKY BLUE GRASS}

Especially suited to meadows and rich lands. It is the grass of the famous limestone soils of Kentucky, and is no less a favorite all through the northern states. A perfect lawn grass. Lb. 35 cts., 5 lbs. $\$ 1.75,10$ lbs. $\$ 3.25$, bus. (20 lbs.) $\$ 6.00$. 
$137 \times$

$-1$

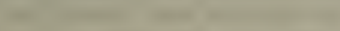

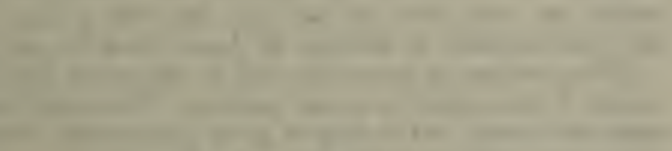

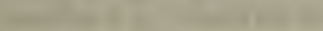

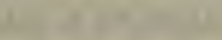




\section{NOTICE !}

WING to unknown crop conditions in September and October when our catalog "HOME LANDSCAPE" went to press, we were then of the opinion that Lawn Seed would remain the same price as last year, but with a short crop it has been necessary to advance all Lawn Seed $5 c$ per pound. When making up your order, add $5 \mathrm{c}$ per pound to the prices quoted, if one pound or twenty pounds. We regret having to make this change but having to go to press months before the new crop came on the market, it is necessary. 


\section{Complete- \\ Landscape Service}

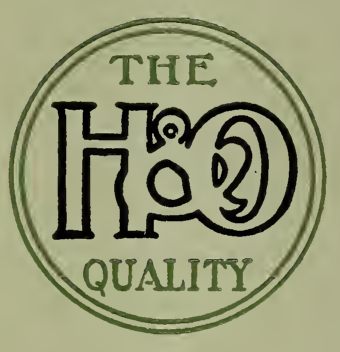

\section{Holm $\mathscr{E}$ Olson, Inc.}

The Park Nurseries

Saint Paul, Minn. 